\title{
Food for Thought: The Neuroscience of Nutrition to Fuel Cognitive Performance
}

Introduction: Fueling Cognitive Performance ......................... 427

I. Developing Lawyer Neuro-Intelligence......................... 430

A. Brain Structure ................................................... 430



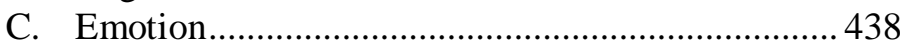

D. Emotions and Stress ............................................. 439

E. Sympathetic Nervous System: Fight-or-Flight ...... 440

F. Parasympathetic Nervous System: Rest-and-



G. Synaptic Transmission ........................................... 443

H. The Brain's Motivation and Reward System......... 445

II. Neuro-Destructive Conditions ..................................... 449

A. Aging and Neurodegenerative Diseases ................ 449

1. Aging .......................................................... 449

2. Mild Cognitive Impairment, Dementia, and Alzheimer's Disease .......................................... 450

3. Cardiovascular Disease .................................. 451

B. Physical Conditions ............................................. 451

1. Weight and Obesity........................................ 451

2. Blood Sugar, Insulin Resistance, and

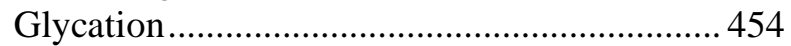

3. Inflammation ................................................... 457

\footnotetext{
* Professor of the Practice, University of Denver Sturm College of Law. Debra's Ph.D. is in Education with an emphasis on Curriculum and Instruction. Her interest in neuroscience stems from a career-long obsession with how people learn, think, and perform effectively. Many thanks to the Rocky Mountain Legal Writing Scholarship Group for their input.
} 
4. Oxidative Stress ................................................ 458

5. Metals and Oxidation ......................................... 459

C. Emotional Conditions ............................................. 460

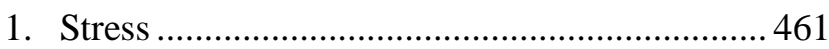

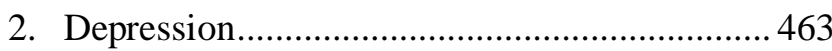

III. Nutrition ................................................................... 466

A. Nutrition and Digestive System Basics ................ 467

B. The Western Diet ................................................ 472

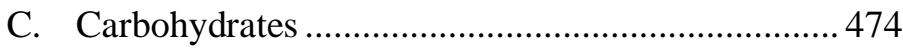

1. Simple Carbohydrates ....................................... 474

2. Complex Carbohydrates.....................................475

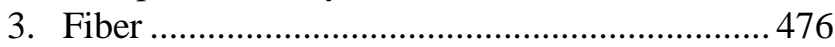

4. How Carbohydrates Work in the Body-Glucose and Glycogen Storage ....................................... 476

5. The Glycemic Index .......................................... 478

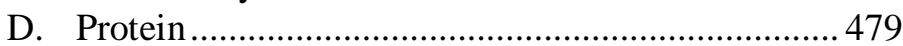

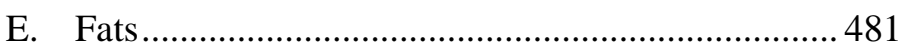

1. Unhealthy Fats ............................................. 483

2. Healthy Fats ................................................ 485

F. Vitamins and Minerals.......................................... 487

1. Vitamin E ........................................................ 487

2. The B Team..................................................... 488

G. Phytochemicals and Antioxidants ......................... 490

IV. Caffeine and Alcohol .................................................. 491



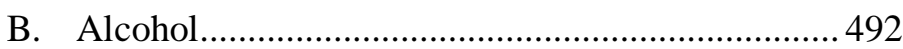

V. Optimizing the Lawyer Brain........................................ 494

A. Brain Health and Popular Diets ............................ 495

1. Paleo Diet........................................................... 495

2. Mediterranean Diet ............................................ 496

3. Whole Food Plant-Based Diet........................... 497

4. Diet Recommendations for the Prevention of Alzheimer's Disease ......................................... 499

5. Diet Recommendations for the Prevention or Improvement of Depression............................ 500

B. Neuro-Protective Nutrition Practices ......................501

1. It's Never Too Late to Start ...............................501

2. Reasons to Get Started ..................................... 502

3. Five Simple Ways to Start ................................ 502

4. Eating Tips: Carbs............................................503

5. Eating Tips: Protein .......................................504 
6. Eating Tips: Fats 505

7. Eating Tips: Vitamins and Minerals 505

8. Eating Tips: Habits 505

9. Foods with Superpowers ....................................5 506

C. Exercise to Enhance Brain Health ......................... 514

Conclusion

\section{INTRODUCTION: FuELING COGNITIVE PERFORMANCE}

In the face of overwhelming odds, I'm faced with only one option. I'm going to have to science the shit out of this.

-Mark Watney played by Matt Damon in The Martian ${ }^{1}$

A lmost nothing is more personal than the decision lawyers make about what to eat for breakfast, lunch, and dinner. In a two-year study examining the health of lawyers, Sharon McDowell-Larsen, $\mathrm{Ph} . \mathrm{D}$., discovered that while ninety-two percent of the participants understood that eating habits have health impacts, half reported they consumed unhealthy diets. ${ }^{2}$ Additionally, none of these lawyers were vegetarians or vegans, fifty-eight percent consumed meat on a daily basis, and sixty-four percent wanted more health and wellness support from their law firms. ${ }^{3}$ Some law firms and law schools are cultivating wellness cultures, but little work has been done in the area of improving lawyer and law student nutrition. ${ }^{4}$

Food choices are influenced by taste, habits, advertising, restaurant/take-out options, time, convenience, and economics. ${ }^{5}$ Most adults consume a core group of foods with about 100 basic items that

1 The Martian (Twentieth Century Fox Film Corporation, TSG Entertainment, Scott Free Productions 2015).

2 Sharon McDowell-Larsen, Improving Performance by Promoting Attorney Health, CTR. FOR CREATIVE LEADERSHIP, http://myccl.ccl.org/leadership/pdf/landing/LawFirm Health.pdf (last visited Mar. 28, 2017).

3 Id.

${ }^{4}$ Susan Swaim Daicoff, Expanding the Lawyer's Toolkit of Skills and Competencies: Synthesizing Leadership, Professionalism, Emotional Intelligence, Conflict Resolution, and Comprehensive Law, 52 SANTA ClARA L. REV. 795, 813 (2012); Mary Kate Sheridan, The Fit Firm: A Law Firm Manager's Guide to Establishing an Effective Wellness Program, 30 Legal Mgmt. 20 (2011). See generally Gretchen Duhaime, Practicing on Purpose: Promoting Personal Wellness and Professional Values in Legal Education, 28 TOURO L. REV. 1207 (2012) (discussing how law schools could implement wellness programs).

5 ANNE M. SMith \& ANGELA L. COLLENE, WARDLAW's CONTEMPORARY NUTRITION 4-6 (10th ed. 2016). 
comprise seventy-five percent of our nutrition. ${ }^{6}$ The top five most commonly purchased food items in America are milk, cereal, bottled water, soft drinks, and bread, and Americans consume nearly twice the carbonated drinks per year (fifty gallons) than either milk (thirty gallons) or water (twenty-five gallons). ${ }^{7}$

The term diet inspires fear and loathing in most people because it implies deprivation. ${ }^{8}$ In The China Study, Dr. T. Colin Campbell conducted a comprehensive study of lifestyle, health, and nutrition, and he presented the story of how food choices can alter lives. ${ }^{9}$ Campbell argues that major American health problems including cancer, heart disease, diabetes, and obesity, can be prevented or greatly improved with the adoption of wise dietary habits. ${ }^{10} \mathrm{He}$ states that Americans are misinformed about the relationship between nutrition and well-being, and there is a tendency to adopt fad diets in an effort to achieve good health. $^{11}$

As a lawyer ages, her physical and mental health tend to deteriorate. ${ }^{12}$ Researchers use neuroimaging to examine the structural and functional integrity of the brain to identify conditions and practices that help or harm the brain. ${ }^{13}$ U.S. Government anti-aging lifestyle research recommends lawyers should strive to exercise daily; maintain healthy weight, cholesterol, blood pressure, and glucose levels; and adopt a nutritious diet. ${ }^{14}$ Research also indicates that the most powerful prescription for improving health, aging well, and reducing the risk of illness is consuming a healthful diet. ${ }^{15}$

\footnotetext{
${ }^{6} I d$. at 5 .

${ }^{7} \mathrm{Id}$.

8 TASNEEm Bhatia, What Doctors EAT: TiPs, RECIPES, AND the Ultimate EATING Plan FOR LASTING WeIgHT LOSS AND PERFECT HEALTH 304 (2013).

9 T. Colin Campbell \& Thomas M. Campbell II, The China Study: The Most COMPREHENSIVE STUDY OF NUTRITION EVER CONDUCTED AND THE STARTLING IMPLICATIONS FOR DIET, WEIGHT LOSS AND LONG-TERM HEALTH 12 (2004) [hereinafter THE CHINA STUDY].

$10 \mathrm{Id}$. at $7,12-15$.

11 Id. at $19-20$.

12 Valentina A. Andreeva \& Emmanuelle Kesse-Guyot, Nutrition and Cognition in the Context of Ageing: Role of Dietary Patterns, in Nutrition for BRAIN HEALTH AND Cognitive PERFoRMANCE 11, 12-13 (Tabitha Best \& Louise Dye eds., 2015).

13 Jose M. Ordovas, Genetics of Brain and Cognition and Their Interactions with Dietary and Environmental Factors, in NUTRITION FOR BRAIN HEALTH AND COGNITIVE PERFORMANCE 64 (Tabitha Best \& Louise Dye eds., 2015).

14 BHATIA, supra note 8 , at 308 (recommending smoking cessation as well).

15 THE CHINA STUDY, supra note 9, at 3.
} 
Changing the way a lawyer eats not only can improve overall health, ${ }^{16}$ but can also change the structure and function of the brain. ${ }^{17}$ The brain requires a disproportionately large amount of the energy resources derived from nutrition relative to the rest of the body, using twenty-five percent of the calories consumed. ${ }^{18}$ Dietary choices can impact the birth of new brain cells, synaptic connections between brain cells, neurotrans mitter pathways, and membrane fluidity. ${ }^{19}$

Cognitive fitness is "the ability to use your mental energy to support your brain and body's efforts to sustain behavior." 20 The brain and body are inclined to invest in energy storage by eating, rather than expend energy exercising, in order to conserve resources. ${ }^{21}$ Overworked and exhausted lawyers often reach for poor sources of energy, such as fast food or processed food. ${ }^{22}$ Proper care for your brain optimizes your mental capacity in the present and builds brain resources for aging. ${ }^{23}$

It is never too early or too late for a lawyer to change eating habits and transform the health of her brain and body. ${ }^{24}$ In a 2006 study, sixtytwo percent of Americans reported greater fear of losing mental function than physical capacity. ${ }^{25}$ "A lawyer's ability to analyze the law and communicate effectively is the most critical tool lawyers have." ${ }^{26}$ Lawyers of all ages can reduce their risk of age-related

$16 \mathrm{Id}$. at 7 .

17 Tabitha Best \& Louise Dye, Good News Story: Nutrition for Brain Health, in Nutrition For BRAIN HEALTH AND COGNITIVE PERFORMANCE 3 (Tabitha Best \& Louise Dye eds., 2015).

18 DANIEl G. AMEN, Change Your Brain Change Your Body: USE Your Brain to Get AND Keep the Body You Have Always Wanted 17 (2010); Valentina A. Andreeva \& Kesse-Guyot, supra note 12, at 28; RITA CARTER, MAPPING THE MIND 14 (rev. ed. 2010) [hereinafter CARTER, MAPPING THE MIND]; GERALD M. EDELMAN, WIDER THAN THE SKY: THE PHENOMENAL GIFT OF CONSCIOUSNESS 15 (2004).

19 Andreeva \& Kesse-Guyot, supra note 12, at 28; Best \& Dye, supra note 17, at 5.

20 Heidi HANNA, The Sharp SOlution: A Brain-BASEd APPrOACh FOR OptiMAL PERFORMANCE 9 (2013).

${ }^{21} \mathrm{Id}$. at 7, 20-21.

$22 I d$. at 6.

23 Id. at $12-13$.

${ }^{24}$ Andreeva \& Kesse-Guyot, supra note 12, at 29; see THE CHINA STUDY, supra note 9, at 7 .

25 Ruth Leyse-Wallace, Nutrition ANd Mental Health 75 (2013). The same study found that twenty-nine percent of this population was more concerned about decreased physical than mental health. Id.

26 Amy Vorenberg, Podia and Pens: Dismantling the Two-Track System for Legal Research and Writing Faculty, 31 COLUM. J. GENDER \& L. 47, 48 (2015). 
cognitive and physical impairment by adopting a nutritious diet, maintaining a healthy weight, and exercising regularly. ${ }^{27}$

This Article aims to inspire nutritional choices that fuel the lawyer's most valuable tool: her brain. Part I of this Article develops the neurointelligence of the law student, law professor, lawyer, and judge. It describes lawyer brain structure, and discusses how the emotional and thinking brains work together to facilitate cognition; response to emotions and stress; and motivation, reward, and habit building. Part II explores neuroscience research on aging and neurodegenerative diseases such as mild cognitive impairment, dementia, and Alzheimer's disease. It examines the brain impact of physical conditions (weight and obesity, blood sugar and glycation, inflammation, and oxidative stress) and emotional conditions (stress and depression). Part III discusses how the brain and body use energy and the impact of nutrients such as carbohydrates, proteins, fats, water, vitamins, and minerals. Part IV addresses the influence of caffeine and alcohol on brain function. Part V critiques Paleo, Mediterranean, and Whole-Food Plant-Based Diets according to their brain health strengths and weaknesses. The Article concludes with recommendations for optimizing the lawyer brain with neuro-protective nutrition and restorative practices that may influence lawyers and motivate them to science the shit out of their approach to brain health.

\section{I}

\section{DEVELOPING LAWYER NEURO-INTELLIGENCE}

\section{A. Brain Structure}

General intelligence, characterized as intellectual quotient (IQ), is a measure of cognitive ability. ${ }^{28}$ Daniel Goleman writes about the capacity to improve social connections with emotional intelligence (EQ). ${ }^{29}$ Body intelligence (BQ) has three pillars: awareness, knowledge, and engagement. ${ }^{30} \mathrm{~A}$ lawyer with BQ cultivates awareness of her body's condition; develops her wellness knowledge base; and

\footnotetext{
27 Andreeva \& Kesse-Guyot, supra note 12, at 12, 29.

28 Nathan Brody, Intelligence and Public Policy, 2 PsychOL. PUB. POL'Y \& L. 473, 473 (1996).

29 See generally DANIEL Goleman, EMOTIONAL INTELligence (1995); DANIEL Goleman, Social InTELligence: THE NEW SCIENCE OF HuMAN RELATIONSHIPS (2006).

30 Jim Gavin \& Margaret Moore, Body Intelligence: A Guide to Self-Attunement, IDEA FITNESS J. (Oct. 19, 2010), http://www.ideafit.com/fitness-library/body-intelligence-a -guide-to.
} 
engages in an action plan of healthy practices. ${ }^{31} \mathrm{~A}$ critical competency for lawyers is the development of neuro-intelligence (NQ) ${ }^{32} \mathrm{~A}$ lawyer with NQ is aware of the condition of her most important asset, her brain; develops brain health literacy; and devises an action plan to enhance neuro-protective practices. ${ }^{33}$

The lawyer brain is the size of a coconut and it weighs only three pounds, yet it requires twenty percent of the body's oxygen, twentyfive percent of its calories, and twenty-five percent of its blood flow to access these resources for fuel. ${ }^{34}$ The eight bones of the cranium protect the brain, which has a consistency of chilled butter or tofu. ${ }^{35}$ The lawyer brain developed into three functional areas that evolved upward from the top of the spine: the primitive brain, the emotional brain, and the thinking brain. ${ }^{36}$

To visualize brain structure, the lawyer can look at her open hand, palm up. ${ }^{37}$ The primitive brain, made up of the brain stem and cerebellum, sits on top of the spine and is located on the hand model where the wrist meets the forearm. ${ }^{38}$ The primitive brain is responsible for survival mechanisms such as breathing, heartbeat, digestion, and sleep. ${ }^{39}$ Fold the thumb across the palm of the hand to envision the emotional brain. ${ }^{40}$ The emotional brain sits over the primitive brain and manages hunger, circadian rhythm, and emotions. ${ }^{41}$ Many major components of the emotional brain come in pairs, one each in the left and right hemispheres, and include the amygdala, hippocampus, hypothalamus, thalamus, nucleus accumbens, and ventral tegmental

\footnotetext{
${ }^{31} I d$.

32 Debra Austin, Drink Like a Lawyer: The Neuroscience of Substance Use and its Impact on Cognitive Wellness, 15 NEV. L.J. 826, 829 (2015).

33 Id.

34 AMEN, supra note 18, at 17; CARTER, MAPPING THE MiND, supra note 18, at 14; EDELMAN, supra note 18, at 15.

35 AMEN, supra note 18, at 18; CARTER, MAPPING THE MIND, supra note 18, at 14; ERIC H. CHUdLER, THE LITTLE BOOK OF NEUROSCIENCE HAIKUS 113 (2013).

36 JUDITH HORSTMAN, THE SCIENTIFIC AMERICAN DAY IN THE LIFE OF YOUR BRAIN 4 6 (2009) [hereinafter HORSTMAN, DAY IN THE LIFE].

37 HANNA, supra note 20, at 26.

38 Id. at 26; BARRY J. GIBB, THE ROUGH GUIDE TO THE BRAIN 36-37 (Duncan Clark \& Ruth Tidball eds., 2007); Judith Horstman, THE SCIENTIFIC AMERICAN BRAVE NEW BRAIN 3 (2010) [hereinafter HORSTMAN, BRAVE NEW BRAIN].

39 GIBB, supra note 38, at 37; HoRSTMAN, BRAVE NEW BRAIN, supra note 38, at 3.

40 HANNA, supra note 20, at 26.

41 GIBB, supra note 38, at 38; HORSTMAN, BRAVE NEW BRAIN, supra note 38, at 4; HORSTMAN, DAY IN THE LIFE, supra note 36, at 4.
} 
area ${ }^{42}$ The emotional brain is engaged when a lawyer creates a new memory or experiences an emotional response. ${ }^{43}$ The thinking brain is also known as the cerebral cortex, and it is wrapped around the emotional brain. ${ }^{44}$ Close the fist and envelope the thumb with the fingers to imagine how the thinking brain encases the emotional brain. ${ }^{45}$ The thinking brain looks like a walnut and if all the folds were flattened, it would be the size of a baby blanket. ${ }^{46}$ Its two hemispheres are linked by the corpus callosum, a bundle of nerves that facilitate communication between them. ${ }^{47}$ The thinking brain is divided into four lobes: frontal (language, reasoning, and planning); occipital (vision); temporal (hearing); and parietal (movement, taste, temperature, and touch). ${ }^{48}$ The lawyer uses the thinking brain for reasoning, executive functions, and higher-order thinking. ${ }^{49}$ The outer covering of the thinking brain is gray matter, which is tightly packed neurons responsible for information processing, and the inner section is white matter where information is transported between parts of the brain. ${ }^{50}$

The lawyer primitive, emotional, and thinking brains are comprised of communication nerve cells called neurons and support cells called glial cells. ${ }^{51}$ Information travels within the brain and between the brain and the body via networks of neurons, and glial cells insulate neurons and facilitate data exchange. ${ }^{52}$ Approximately ten percent of lawyer brain cells are neurons and ninety percent are glial cells. ${ }^{53}$

Neurons are shaped like trees with information-receiving branches at the top called dendrites, a cell body with a nucleus, a trunk called an

\footnotetext{
42 Rita CARTer et Al., THE Human Brain BoOK 64, 128 (Tony Phipps et al. eds., 2009) [hereinafter CARTER ET AL., THE Human BRAin]; Horstman, DAY IN THE Life, supra note 36 , at $4-5$.

43 GIBB, supra note 38 , at 39.

44 Michael S. Sweeney, Brain: The Complete Mind 20, 39 (Amy Briggs ed., 2009).

45 HANNA, supra note 20, at 27.

46 CARTER, MAPPING THE MIND, supra note 18, at 14; JOHN MEDINA, BRAIN IDEAS: 12 PRINCIPLES FOR SURVIVING AND THRIVING AT WORK, HOME AND SCHOOL 102 (Tracy Cutchlow ed., 2009).

47 GIBB, supra note 38, at 41; SwEENEY, supra note 44, at 20.

48 HORSTMAN, DAY IN THE LIFE, supra note 36, at 6; CARTER, MAPPING THE Mind, supra note 18, at 14; CARTER ET AL., THE HUMAN BRAIN, supra note 42, at 66; GIBB, supra note 38 , at 40 .

49 DAVid Perlmutter \& Alberto Villoldo, POWER Up Your Brain 19-20 (2011).

50 CARTER, MAPPING THE MIND, supra note 18, at 14-15; GIBB, supra note 38 , at 40 , $118-22$.

51 CARTER ET AL., THE HUMAN BRAIN, supra note 42, at 69.

52 SWEENEY, supra note 44, at 10-11.

53 CARTER ET AL., THE HuMAN BRAIN, supra note 42, at 69.
} 
axon, and information-output roots called axon terminals. ${ }^{54}$ Information travels one direction through the neuron, entering the dendrites and flowing through the axon, then exiting the axon terminals. ${ }^{55}$ The site where data output axon terminals meet input dendrites on the next neuron is the synapse. ${ }^{56}$ Dendrites and synapses are eighty percent lipid. ${ }^{57}$ Lipids are fats (solid at room temperature) and oils (liquid at room temperature). ${ }^{58}$ Information travels within the neuron as an electrical impulse, but it crosses the synapse to reach the next neuron via chemical neurotransmitter. ${ }^{59}$ Each neuron connects with up to 10,000 other neurons utilizing over 100 neurotransmitters, some of the most important of which include: acetylcholine (attentiveness, memory); dopamine (motivation, meaning, reward, repeat behavior); endorphins (pain reduction, pleasure); glutamate (learning, memory, excites brain activity); gamma-aminobutyric acid or GABA (calms brain activity); norepinephrine (mood, arousal, attention, perception, motivation); oxytocin (bonding); and serotonin (mood, anxiety, sleep). ${ }^{60}$

Neurotransmitters are deployed continuously in the lawyer brain during chemical synaptic transmissions. ${ }^{61}$ Each neurotransmitter can dock only in a specialized receptor on the dendrite's surface. ${ }^{62}$ Neurotransmitters either excite the receptor cell to fire or inhibit its activity. ${ }^{63}$ Each lawyer brain has a unique network of neurons, called the connectome, which links her brain regions. ${ }^{64}$

54 Id. at 68-69; JOSEPH LEDOUX, SYNAPTIC SELF 40-41 (2002); SWEENEY, supra note 44 , at $10-11$.

55 GIBB, supra note 38 , at 33-35.

56 CARTER ET AL., THE HUMAN BRAIN, supra note 42, at 69; LEDOUX, supra note 54, at $40-42$.

57 LEYSE-WALLACE, supra note 25, at 97.

58 SMITH \& COLLENE, supra note 5, at 11.

59 LEDOUX, supra note 54, at 47.

60 CARTER, MAPPING THE MIND, supra note 18, at 16, 29; HORSTMAN, DAY IN THE LIFE, supra note 36, at 6, 8; PRINCIPLES OF NEURAL SCIENCE 213, 293-94 (Eric R. Kandel \& James H Schwartz eds., 5th ed. 2013); JOHN J. RATEY, SPARK: THE REVOLUTIONARY NEW SCIENCE OF EXERCISE AND THE BRAIN 37 (2008) [hereinafter RATEY, SPARK]; SWEENEY, supra note 44 , at 15.

61 MARK F. BeAr ET AL., Neuroscience: Exploring THE Brain 122 (4th ed. 2016).

62 SWEENEY, supra note 44 , at $14-15$.

63 Id. at 15.

64 MedinA, supra note 46, at 66; PRINCIPLES OF NEURAL SCIENCE, supra note 60, at 1524; SEbastian SEUNG, CONNECTOME: How the BRAIN's WIRING MAKES Us WHO WE ARE xiii (2012). 
Three key properties of lawyer brain transformation are neuroplasticity, neurogenesis, and epigenetics. Neuroplasticity gives the brain the capacity to reshape its neural circuits with each new experience. ${ }^{65}$ The brain adapts to new knowledge and events by rewiring the hundreds of millions of connections between neurons. ${ }^{66}$ The brain also evolves throughout the lawyer's life with the birth of new brain cells in the hippocampus (the brain's memory processor) and the olfactory bulbs (responsible for smell) in a process called neurogenesis. ${ }^{67}$ Neurogenesis can be stimulated by exercise, learning, and antidepressants, but suppressed by stress. ${ }^{68}$ Exercise increases the production of brain-derived neurotropic factor (BDNF), a substance that enhances neuron growth and survival in the hippocampus. ${ }^{69} \mathrm{BDNF}$ acts like a fertilizer for hippocampal neurons and it encourages synapse formation, the connection between neurons that is vital for learning and thinking. ${ }^{70}$ Epigenetics is the study of how environments impact gene regulation. ${ }^{71}$ Personal experiences change the way genes are expressed, that is, turned on or off, via proteins called the epigenome. ${ }^{72}$ The lawyer brain can be harmed by illness and poor treatment, healed with healthy practices, and amplified by stimulating environments. ${ }^{73}$

\section{B. Cognition}

Lawyers with NQ understand how the brain processes information and how learning and memory function. Lawyering involves lifelong learning. When faced with client issues, lawyers must research the

\footnotetext{
65 SWEENEY, supra note 44, at 17.

66 NoRMAn DoIDGE, THE BRAIN ThAT CHANGES ITSELF 46-47 (2007).

67 CARTER ET AL., The Human Brain, supra note 42, at 64; Horstman, Brave NEW BRAIN, supra note 38 , at 8,10 .

68 ROBERT M. SAPOLSKY, WHY ZEBRAS DON'T GET UlCERS 217-18 (3d ed. 2004); SWEENEY, supra note 44, at 294.

69 DOIDGE, supra note 66, at 255; RATEY, SPARK, supra note 60, at 50-53.

70 SANDRA AAMODT \& SAM WANG, WELCOME TO YOUR BRAIN 89 (2008); AMEN, supra note 18, at 110; see DEEPAK CHOPRA \& RUDOLPH E. TANZI, SUPER BRAIN 34-35 (2012); MedinA, supra note 46, at 22; PERLMUTTER \& VILlOLDO, supra note 49, at 87; PRINCIPLES OF NEURAL SCIENCE, supra note 60, at 1202-03.

71 Margaret Joy Dauncey, Nutrition, Genes, and Neuroscience: Implications for Development, Health, and Disease, in DIET AND EXERCISE IN COGNITIVE FUNCTION AND NEUROLOGICAL DisEASES 1, 4 (Tahira Farooqui \& Akhlaq A. Farooqui eds., 2015); JOHN J. RATEY \& RiCHARD MANNING, Go WILD 235 (2014) [hereinafter RATEY, Go WILD].

72 DOIDGE, supra note 66, at 220; HORSTMAN, BRAVE NEW BRAIN, supra note 38, at 13.

73 CARTER ET AL., THE HuMAN BRAIN, supra note 42, at 193; SwEENEY, supra note 44,
} at 13 . 
current state of the law and apply it to the client problem. Experienced lawyers will also use their memory in service to client problem-solving.

Cognition involves the complicated mental processes of attention, memory, learning, knowledge acquisition, intelligence, and consciousness. ${ }^{74}$ The quality of these processes depends upon communication between neurons. ${ }^{75}$ As the lawyer ages, the speed with which her neurons receive and transmit these signals slows, weakening learning and recall. ${ }^{76}$ Normal aging also involves a decline in the number of synapses and a reduction in the volume of brain structures including the hippocampus, cerebellum, and prefrontal areas, which could contribute to cognitive problems. ${ }^{77}$ Cognitive decline in the aging lawyer can range from normal memory complaints, to mild cognitive impairment, dementia, and Alzheimer's disease. ${ }^{78}$

Alzheimer's disease is the sixth leading cause of death in the United States and the most common form of dementia. ${ }^{79}$ It is a slow-moving fatal brain disorder that "starts with memory loss and ends with severe brain damage." ${ }^{80}$ Victims of Alzheimer's disease have amyloid plaques and neurofibrillary tangles in their brain. ${ }^{81}$ Beta amyloid kills brain cells, particularly in the hippocampus, and impairs synapses. ${ }^{82}$ More women are stricken with Alzheimer's than men, and after age sixtyfive about one in six women and one in eleven men will succumb to Alzheimer's disease. ${ }^{83}$

Learning involves the acquisition of new information and memory is how that information is stored in the brain. ${ }^{84}$ Learning comprises cognitive mechanisms, such as memorizing new regulations that govern a client activity; motor mechanisms, such as typing a letter explaining how the rules impact the client; and affective mechanisms,

\footnotetext{
74 Andreeva \& Kesse-Guyot, supra note 12, at 14.

75 Id.

$76 \mathrm{Id}$.

77 Id.

78 Id. Mild Cognitive Impairment is discussed further in Part II.A.2, infra.

79 Alzheimer's Disease Fast Facts, CNN, http://www.cnn.com/2013/08/23/health /alzheimers -disease-fast-facts (last updated May 31, 2016) [hereinafter Fast Facts].

$80 \mathrm{Id}$.

$81 \mathrm{Id}$.

82 Dmitri P. Agamanolis, Chapter 9: Degenerative Diseases, Neuropathology: AN ILlUSTRATED INTERACTIVE COURSE FOR MED. STUDENTS AND RESIDENTS, http://neuro pathology-web.org/chapter9/chapter9bAD.html (last updated Aug. 2016).

83 Fast Facts, supra note 79.

84 SWEENEY, supra note 44, at 236.
} 
such as pride at delivering optimal client service or relief when a sticky client matter reaches resolution. ${ }^{85}$

Learning involves a complex interaction between the emotional and thinking brain. Information enters the thinking brain through the senses. ${ }^{86}$ The occipital lobe processes visual information, the temporal lobe processes sound, the frontal lobe processes language, and the temporal lobe processes information involving movement, touch, or taste. ${ }^{87}$ These information traces move from the thinking brain to the emotional brain, where the thalamus focuses the brain's attention, screens and sorts the information traces, and sends them to the hippocampus. ${ }^{88}$ The amygdala filters the information for emotional content and becomes involved in the storage of emotionally charged information. ${ }^{89}$ The information travels back to the thinking brain, to the sensory lobe of its origin, then returns to the hippocampus in the emotional brain, forming a loop. ${ }^{90}$ Information travels along this thinking-emotional brain circuit via neurons and neurotransmitters. ${ }^{91}$

The processing of sensory information as it enters the brain is called encoding. ${ }^{92}$ Memory traces are converted into long-term memory during consolidation, making information more stable in the brain. ${ }^{93}$ Rehearsal or practice, such as re-reading a set of new statutes or studying for an exam, requires neurons to fire along the same pathway in the brain, which strengthens their connections and is called longterm potentiation. ${ }^{94}$ This same process occurs in the lawyer brain for procedural memories, such as skills like snowboarding, typing, or driving; ${ }^{95}$ fear memories, such as a phobia regarding spiders or humiliation during a law school Socratic interrogation; ${ }^{96}$ episodic

85 See Your Brain: A User's Guide, NAT'L GEOGRAPHIC, 2012, at 21.

86 SWEENEY, supra note 44, at 248.

87 GIBB, supra note 38, at 40; HORSTMAN, DAY IN THE LIFE, supra note 36, at 6.

88 See CARTER ET AL., THE HuMAN BRAIN, supra note 42, at 60; EDELMAN, supra note 18 , at $19-21$.

89 CARTER ET AL., THe HumAn BRAIN, supra note 42, at 160; SweENEY, supra note 44, at $242,252$.

90 See CARTER ET AL., THE HuMAN BRAIN, supra note 42, at 158-61.

91 See CARTER, MAPPING THE MIND, supra note 18, at 159.

92 Tracey Tokuhama-Espinosa, Mind, Brain, AND Education Science 261 (2011).

93 MEDINA, supra note 46, at 125-26; PRINCIPLES OF NEURAL SCIENCE, supra note 60, at 1447.

94 See CARTER, MAPPING THE MIND, supra note 18, at 159-60; SWEENEY, supra note 44 , at 213.

95 See SWEENEY, supra note 44, at 242-43.

96 See CARTER, MAPPING THE MIND, supra note 18, at 162. 
memories, which are autobiographical events such as family vacations $;{ }^{97}$ and semantic memories, which are learned facts, words, and concepts important to legal education and the lifelong learning required of attorneys. ${ }^{98}$

Procedural memory motor skills are stored in the primitive brain in the cerebellum. ${ }^{99}$ Fear memories are stored in the emotional brain in the amygdala. ${ }^{100}$ These memories reside in the unconscious mind. ${ }^{101}$

Outlining, analyzing, synthesizing, and studying strengthen the synaptic connections in the neural networks of the lawyer brain. ${ }^{102}$ Episodic and semantic memories require effortful processing to recall. ${ }^{103}$ The early lives of these memories are stored not in a single location, but in the memory consolidation loop circulating from the hippocampus in the emotional brain to the sensory lobes in the thinking brain. ${ }^{104}$ Information travels the emotional-thinking brain circuit for years-perhaps for as few as two years to as long as a decadegradually evolving from a fragile to a stable memory. ${ }^{105}$ Scientists believe this journey takes place largely during sleep, making it one of the most important activities a lawyer can improve on to nourish her brain function. ${ }^{106}$ Law students writing papers and taking exams or new lawyers accessing information learned in law school and reinforced during bar exam preparation are retrieving that information from the emotional-thinking brain loop. ${ }^{107}$

Once the consolidation process is complete, the hippocampus lets go of its relationship with the sensory lobes, and memory resides in the

\footnotetext{
97 See id. at 162; GIBB, supra note 38, at 69.

98 See GIBB, supra note 38, at 69; SwEENEY, supra note 44, at 243.

99 SWEENEY, supra note 44, at 240-43.

100 CARTER, MAPPING THE MIND, supra note 18, at 162.

101 See SWEENEY, supra note 44, at 240-43.

102 See CARTER, MAPPING THE Mind, supra note 18, at 162-64; CARTER ET AL., THE HUMAN BRAIN, supra note 42, at 159.

103 MEDINA, supra note 46, at 131-32.

104 Id. at $112-13$.

105 See CARTER, MAPPING THE Mind, supra note 18, at 161-62, 164; CARTER ET AL., THE HUMAN BRAIN, supra note 42, at 160-61; MEDINA, supra note 46, at 138, 140-42.

106 See CARTER, MAPPING THE Mind, supra note 18, at 163, 165; CARTER ET AL., THE HUMAN BRAIN, supra note 42 , at 161; GIBB, supra note 38, at 68; SWEENEY, supra note 44 , at 246.

107 See CARTER ET AL., The HumAn Brain, supra note 42, at 160-61; CARTER, MAPPING THE MIND, supra note 18, at 162-65.
} 
thinking brain. ${ }^{108}$ This neural network, unique to each lawyer because it was constructed from individual experiences, emotions, and thoughts, is called the connectome. ${ }^{109}$ Experienced lawyers combine recall of stable information from their connectome with retrieval of newer information from their emotional-thinking brain circuit to counsel and represent clients. ${ }^{110}$

Emotional information often accompanies visual, auditory, and language information as it is encoded by the brain. ${ }^{111}$ The qualities of emotional information can impact memory formation. ${ }^{112}$

\section{Emotion}

When the brain detects a positively or negatively charged stimulus, both the brain and the body experience an automatic and unconscious physiological response. ${ }^{113}$ Physical responses to emotions include facial expressions, blushing, sweaty palms, increased heart rate, and elevated blood pressure. ${ }^{114}$ Emotions are experienced as feelings, the conscious perceptions of automatic responses by the body. ${ }^{115}$

Scientists recognize four basic emotions: fear, anger, sadness, and joy; ${ }^{116}$ some add disgust and surprise. ${ }^{117}$ Emotional information is processed by the brain through two parallel routes. ${ }^{118}$ On the "quick and dirty route," information moves from the thinking brain lobes to the amygdala where it is assessed for potential as a threat or opportunity and can stimulate the survival mechanisms of flight, fight, or pacification. ${ }^{119}$ On the slower route, information is processed by the

108 CARTER, MAPPING THE MIND, supra note 18, at 162; see MEDINA, supra note 46, at 138.

109 SEUNG, supra note 64, at 79-80; Mark I. Sirkin, Managing Your Brain - A User's Guide, 82 N.Y. ST. B. Ass'N J. 38, 39 (2010).

110 See CARTER, MAPPING THE MIND, supra note 18, at 162, 165.

111 CARTER ET AL., THE HUMAN BRAIN, supra note 42, at 158, 160; TOKUHAMAESPINOSA, supra note 92, at 143-49.

112 CARTER ET AL., THE HUMAN BRAIN, supra note 42, at 160; SWEENEY, supra note 44, at 212 .

113 GIBB, supra note 38, at 96; PRINCIPLES OF NEURAL SCIENCE, supra note 61, at 1079.

114 CARTER, MAPPING THE Mind, supra note 18, at 82; CARTER ET AL., THE HUMAN BRAIN, supra note 42, at 124; SWEENEY, supra note 44, at 208.

115 CARTER ET AL., THE HUMAN BRAIN, supra note 42, at 126; PRINCIPLES OF NEURAL SCIENCE, supra note 61, at 1079.

116 SWEENEY, supra note 44, at 208.

117 CARTER ET AL., THE HUMAN BRAIN, supra note 42, at 128-29.

118 CARTER, MAPPING THE MIND, supra note 18 , at 83.

119 Id. at 83-84; CARTER ET AL., THE HUMAN BRAIN, supra note 42, at 125; SUSAN GREENFIELD, THE PRIVATE LIFE OF THE BRAIN 18 (2000); SwEENEY, supra note 44, at 215. 
thinking brain and the hippocampus, and, absent a threat, the thinking brain overrules the amygdala and inhibits the fight-or-flight response. ${ }^{120}$

The neuroscientist that made the amygdala famous, Joseph LeDoux, has demonstrated that more neural signals travel up from the emotional brain to the thinking brain than down from the thinking brain to the emotional brain, suggesting that the emotional brain has more influence over behavior than does the thinking brain. ${ }^{121}$

\section{Emotions and Stress}

Walter B. Cannon and Hans Selye were important stress researchers. ${ }^{122}$ Canon described the fight-or-flight stress response, ${ }^{123}$ and Selye used the term stress to label the discomfort his lab rats experienced when he frequently dropped, chased, and recaptured them. ${ }^{124}$ Selye noticed that the general unpleasantness of extended exposure to a variety of stressors made his rats sick. ${ }^{125}$

When law school or law practice subjects students or lawyers to a broad array of stressors, the general unpleasantness is likely to make them sick. ${ }^{126}$ Lawyers suffer from higher levels of anxiety and depression than the rest of the population, but they don't enter law school with these disorders. ${ }^{127}$ Lawyers rank fourth in professions with the highest number of suicides. ${ }^{128}$ Overwork is a habit law students

120 SWEENEY, supra note 44, at 215.

121 CARTER, MAPPING THE Mind, supra note 18, at 98 (quoting JOSEPH LeDouX, THE EMOTIONAL BRAIN (1996)); SAPOLSKY, supra note 68, at 323.

122 See SAPOLSKY, supra note 68, at 7-12 (discussing Cannon and Selye's stress research).

123 Id. at 12.

124 Id. at $9-10$.

125 Id.

126 See id. at 8-10 (explaining how environmental and psychological stressors lead to stress and ultimately sickness).

127 See NANCy LeVit \& Douglas O. Linder, THE HAPPy LaWyer 6-8 (2010); DOUglas Litowitz, The Destruction OF YOUNG LAWYERS: BeyOND ONE L 16-26 (2006); ANDREW J. MCCluRG, 1L OF A RIDE 315-17 (2009); REBECCA NERISON, LAWYERS, ANGER, AND ANXIETY 15-39 (2010); Lawrence S. Krieger, Institutional Denial About the Dark Side of Law School, and Fresh Empirical Guidance for Constructively Breaking the Silence, 52 J. LEGAL EDUC. 112, 113-15 (2002); Corie Rosen, The Method and the Message, 12 NEV. L.J. 160, 161 n.8 (2011).

128 Rosa Flores \& Rose Marie Arce, Why Are Lawyers Killing Themselves?, CNN (Jan. 20, 2014, 2:42 PM), http://www.cnn.com/2014/01/19/us/lawyer-suicides/index.html; see also Patrick Krill, Why Lawyers Are Prone to Suicide, CNN (Jan. 21, 2014, 10:15 AM), http://www.cnn.com/2014/01/20/opinion/krill-lawyers-suicide/index.html (explaining that 
likely develop in law school where success is defined in terms of GPA, class rank, and service on law journals. ${ }^{129}$ Lawyer anxiety, depression, and high suicide rates are likely linked to perpetual overwork and chronic stress. ${ }^{130}$

The brain and body work in concert to produce the general unpleasantness of the stress response and to recover from damage caused by stress. The autonomic nervous system has two halves that are in charge of maintaining balance: the sympathetic nervous system (fight-or-flight) and the parasympathetic nervous system (rest-anddigest). ${ }^{131}$ Fight-or-flight is the body's arousal system accelerator, and rest-and-digest is its calming system brake. ${ }^{132}$

\section{E. Sympathetic Nervous System: Fight-or-Flight}

The fight-or-flight system evolved to motivate a rapid response to predators. ${ }^{133}$ This system is activated during acute stress, and is intended to help with short-term challenges like a court appearance or a weekend fun-run. ${ }^{134}$ This system can be persistently activated during chronic stress caused by long-term problems such as job loss, financial difficulties, troubled relationships, and possibly law school or law practice. ${ }^{135}$

The fight-or-flight stress response begins when the thinking brain detects a threat and this information is directed via the quick and dirty route to the "brain's panic button"- the amygdala. ${ }^{136}$ The amygdala directs the thalamus to focus attention and the hypothalamus to release the stress hormones adrenaline and glucocorticoids (the key glucocorticoid is cortisol). ${ }^{137}$ Stress hormones increase heart rate,

suicide "is the third leading cause of death in the profession," but "only the [tenth] leading cause of death in the general population").

129 See LEVIT \& LINDER, supra note 127 , at 125.

130 Id. at 7.

131 Dale Purves et AL., Principles of Cognitive Neuroscience 326 (2d ed. 2012); Andrea C. Gore, Neuroendocrine Systems, in FundAMENTAL NeUROSCIENCE 730 (Larry Squires et al. eds., 4th ed. 2013).

132 See Linda Graham, Bouncing Back: Rewiring Your Brain FOR MAXIMUM RESILIENCE AND WELL-BEING 200-01 (2013) (describing the amygdala's role in the fightor-flight response).

133 Gore, supra note 131, at 803.

134 See PERLMUTTER \& VILLOLDO, supra note 49, at 59 (explaining the effects of acute stress).

135 See id

136 RATEY, SPARK, supra note 60, at 62.

137 CARTER ET AL., THE HUMAN BRAIN, supra note 42, at 232 (stating that the pituitary gland and the hypothalamus in the emotional brain tell the adrenal gland sitting atop the 
elevate blood pressure, mobilize energy, slow digestion, and suppress the immune system. ${ }^{138}$ Symptoms of chronic stress response include dizziness, breathlessness, sweating, chills, muscle tension, panic attacks, heart palpitations, stomach discomfort, and chest pain. ${ }^{139}$ The stress response is designed to deal with short-term challenges, but chronic stress causes the long-term release of stress hormones, which results in a compromised immune system; decreased muscle mass and bone density; and increased appetite, body fat, irritability, anger, anxiety, and depression. ${ }^{140}$

Lawyers and law students can spend months or years in fight-orflight overdrive, many believing their performance is enhanced by stress hormones. ${ }^{141}$ Chronic stress response harms the lawyer brain because the amygdala's reaction to stress hormones is to produce additional stress hormones. ${ }^{142}$ The brain's memory processor, the hippocampus, has ample glucocorticoid receptors, thus it is highly susceptible to stress. ${ }^{143}$ Stress hormones damage and kill neurons in the hippocampus and weaken the remaining synaptic connections. ${ }^{144}$ The remaining brain cells don't work as well as they did prior to exposure to stress. ${ }^{145}$ When stress hormones damage the hippocampus, it responds by producing additional stress hormones, creating a cycle of self-destruction. ${ }^{146}$

kidneys to release adrenaline and glucocorticoids); MEDINA, supra note 46, at 174; PERLMUTTER \& VILLOLDO, supra note 49, at 60; SWEENEY, supra note 44, at 40; Gore, supra note 131, at 799, 804; Steven E. Hyman \& Jonathan D. Cohen, Disorders of Mood and Anxiety, in PRINCIPLES OF NEURAL SCIENCE, supra note 60, at 1402, 1409.

138 PERLMUTTER \& Villoldo, supra note 49, at 60; Gore, supra note 131, at 804; see SAPOLSKY, supra note 68, at 13.

139 See CARTER ET AL., THE HuMAN BRAIN, supra note 42, at 232.

140 See SAPOLSKY, supra note 68, at 13-14; Shawn M. TAlbotT, THE CoRTisOL CONNECTION 22 (Alexandra Mummery, 2nd ed. 2007); see also MEDINA, supra note 46, at $175-76$.

141 See Gayatri Devi, A Calm Brain: How to Relax Into A Stress-Free, HighPOWERED LIFE 6 (2012).

142 See Rick Hanson with Richard MENDIUs, BudDhA's Brain: THE PRACTICAL NEUROSCIENCE OF HAPPINESS, LOVE, \& WISDOM 52-53 (2009); see also RATEY, SPARK, supra note 60 , at $62,66-67$.

143 MEDINA, supra note 46, at 177; Gore, supra note 131, at 804.

144 See AAMODT \& WANG, supra note 70, at 86; AMEN, supra note 18, at 248; MEDINA, supra note 46, at 179; DAVID A. SOUSA, HOW BRAIN SCIENCE CAN MAKE YOU A BETTER LAWYER 25 (2009); Gore, supra note 131, at 804.

145 SAPOLSKY, supra note 68 , at 215.

$146 \mathrm{Id}$. at 387. 
Brain scans indicate that hippocampi shrink in people who experience stress, low self-esteem, repeated jet lag, major depression, and post-traumatic stress disorder (PTSD). ${ }^{147}$ Neuroscientists have proven that cognitive performance is diminished during the fight-orflight stress response. ${ }^{148}$ The impact of stress on cognition includes impaired concentration, memory, problem-solving, and language and math processing. ${ }^{149}$ Motivation, creativity, and curiosity are dampened. ${ }^{150}$

Law school and law practice are replete with sources of stress that activate the stress response: intense workload, competitive environment, technology overload, and the demand of 24/7 availability. ${ }^{151}$ The panic button amygdala drives a negativity bias, and the mind can trigger a stress response by simply imagining a threatening situation, such as being called on in class, worrying about the number of hours billed, or a client outcome. ${ }^{152}$ Thinking brain capacity is diminished during the stress response making it very difficult to suppress apprehension. ${ }^{153}$ The legal profession presents many stressors, and emotional reactions to problems can spark the stress response more often than the presence of an actual threat. ${ }^{154}$ The damage caused by chronic stress response can be healed, thanks to neuroplasticity, when lawyers learn to enhance their rest-and-digest system. ${ }^{155}$

\section{F. Parasympathetic Nervous System: Rest-and-Digest}

The other half of the autonomic nervous system is the parasympathetic nervous rest-and-digest system. ${ }^{156}$ While the fight-orflight stress response activates arousal, defense, and escape, the restand-digest system promotes nourishment, procreation, and a return to

\footnotetext{
147 Best \& Dye, supra note 17, at 4; SAPOLSKY, supra note 68, at 221.

148 HANSON, supra note 142, at 52-60; RATEY, SPARK, supra note 60, at 67-71; see DEVI, supra note 141 , at $83-86$.

149 MEDINA, supra note 46, at 178-79.

150 See PeRlmutTER \& Villoldo, supra note 49, at 61.

151 See DEVI, supra note 141, at 22-33.

152 RATEY, SPARK, supra note 60 , at 62-63.

153 See HANSON, supra note 142, at 50-53.

154 HANSON, supra note 142, at 50; RATEY, SPARK, supra note 60, at 83.

155 HANSON, supra note 142, at 52-60; see RATEY, SPARK, supra note 60, at 67-71; see DEVI, supra note 141, at 83-86.

156 HANSON, supra note 142, at 58-59; Gore, supra note 131, at 734.
} 
balance following stress response activation. ${ }^{157}$ The rest-and-digest system promotes digestion and nutrient absorption, slows heart rate, lowers blood pressure, limits heat loss, curbs the release of stress hormones, and supports rest. ${ }^{158}$ It conserves energy, produces feelings of calm and contentment, and restores equilibrium after stress response activation. ${ }^{159}$ To enhance the rest-and-digest system and foster stress resilience, lawyers and law students can engage in restorative practices and consume a healthy diet. ${ }^{160}$

\section{G. Synaptic Transmission}

The neuron is the key unit of communication in the brain. It uses an electrochemical process of transmitting information between areas of the brain and between the brain and the body. ${ }^{161}$ During synaptic transmission, an electrical impulse travels through the neuron and triggers the release of a chemical neurotransmitter to carry the signal from the axon terminals of the pre-synaptic neuron to the dendrites of the post-synaptic neuron. ${ }^{162}$ Synaptic transmission has four stages: (1) synthesis and storage of the neurotransmitter in the pre-synaptic neuron; (2) neurotransmitter release; (3) interaction of the neurotransmitter with the receptors on the post-synaptic neuron; and (4) removal of the neurotransmitter from the synaptic cleft. ${ }^{163}$

In order to complete the communication between neurons, neurotransmitters must bind to the receptors on the dendrites of the post-synaptic neuron. ${ }^{164}$ Receptors can recognize the specific shape of

157 David G. Amaral \& Peter L. Strick, The Organization of the Central Nervous System, in PRINCIPLES OF NEURAL SCIENCE, supra note 60, at 337, 353; John P. Horn \& Larry W. Swanson, The Autonomic Motor System and the Hypothalamus, in PRINCIPLES OF NEURAL SCIENCE, supra note 60, at 1066.

158 William J. BROAD, THE SCIENCE OF Yoga: THE RISKS AND REWARDS 90 (2012); DEVI, supra note 141, at 53; SWEENEY, supra note 44, at 41; Gore, supra note 131, at 734, 736.

159 CHUDLER, supra note 35, at 35; HANSON, supra note 142, at 59; Amaral, Strick, Horn \& Swanson, in PRINCIPLES OF NEURAL SCIENCE, supra note 60, at 353, 1066.

160 AMEN, supra note 18, at 167; GRAHAM, supra note 132, at 208; HANSON, supra note 142, at 110; NERISON, supra note 127, 154-55; see also DEVI, supra note 141 , at 37.

161 CARTER ET AL., THE HUMAN BRAIN, supra note 42, at 41.

162 LEDOUX, supra note 54, at 45; MEDINA, supra note 46, at 55.

163 James H. Schwartz \& Jonathan A. Javitch, Neurotransmitters, in PRINCIPLES OF NEURAL SCIENCE, supra note 60, at 289.

164 DAVID J. LiNDEN, THE COMPASS OF PLEASURE 1617 (2011). 
neurotransmitters, or that of drugs that mimic neurotransmitters. ${ }^{165}$ Neurotransmitters or drugs with the best chemical fit, called agonists, attach to the receptors and activate them. ${ }^{166}$ Those that fit into and bind to receptors, but do not activate them, are called receptor antagonists. ${ }^{167}$ Antagonists block the receptor and prevent its activation. ${ }^{168}$ Receptors respond to an absence of agonists (activating neurotransmitters) by increasing their numbers, and the receptor growth process is known as up-regulation. ${ }^{169}$ When receptors are persistently activated by the presence of too much neurotransmitter, the neuron reduces the number of receptors in a process called downregulation. ${ }^{170}$

An example of down-regulation occurs when consumption of a poor diet causes chronic elevation of blood glucose and the body responds with an increase in insulin production. ${ }^{171}$ When the endocrine system learns to expect high insulin levels, it reduces the number of insulin receptors, and the down-regulation causes insulin resistance. ${ }^{172}$

When networks of neurons fire repeatedly during long-term potentiation, they are strengthened. ${ }^{173}$ Canadian psychologist Donald Hebb described long-term potentiation as the process in which brain "cells that fire together wire together." 174 The brain continuously evolves and rewires itself with every experience, thought, and feeling. ${ }^{175}$ Long-term potentiation is the basis of neuroplasticity. ${ }^{176}$ Lawyer choices and practices, whether healthy or unhealthy, become ingrained with repetition.

165 JERROLD S. MEYER \& LINDA F. QUENZER, PSYCHOPHARMACOLOGY: DRUGS, THE BRAIN, AND BEHAVIOR 2728 (2d ed. 2013).

166 Id. at 28.

167 Id.

168 Id.

169 Id.

170 Id.

171 RATEY, Go WILD, supra note 71, at 235-36.

172 Id. at 236

173 CARTER, MAPPING THE MIND, supra note 18, at 160; LINDEN, supra note 164, at 55; SWEENEY, supra note 44, at 248.

174 LEDOUX, supra note 54, at 79.

175 RATEY, SPARK, supra note 60, at 36.

176 Joseph R. Manns \& Elizabeth A. Buffalo, Learning and Memory: Brain Systems, in FUNDAMENTAL NEUROSCIENCE, supra note 131, at 1029-30. 


\section{H. The Brain's Motivation and Reward System}

Cognition involves a complex interaction between the emotional and thinking brain. ${ }^{177}$ The learning system that involves knowledge acquisition and memory formation requires the brain to encode, consolidate, and retrieve information. ${ }^{178}$ Newer memories are retrieved from the emotional-thinking brain loop made up of the hippocampus and sensory lobes, ${ }^{179}$ and fully consolidated memories are recalled from the knowledge network connectome in the thinking brain. ${ }^{180}$

Motivation and reward also involve a complicated interface between the emotional brain and the thinking brain. ${ }^{181}$ Reward seeking has six stages: incentive (or stimulus), desire, motivation, action, reward, and learning. ${ }^{182}$ An incentive creates a feeling of desire; for example, when the smell of fresh baked bread (an external stimulus) or falling glucose levels (an internal stimulus) produce the desire to eat. ${ }^{183}$ Desire is longing for a reward you believe will produce pleasure or satisfaction. ${ }^{184}$ Motivation is the ambition to obtain a reward, and learning is the process that occurs when action leads to the acquisition of the reward. ${ }^{185}$ Pleasure is the feeling that is experienced when acquisition of a reward results in satisfaction or enjoyment. ${ }^{186}$

Dopamine is the neurotransmitter that has long been associated with reward seeking. ${ }^{187}$ The evolutionary purpose of the dopamine system is to stimulate eating and procreation to ensure survival. ${ }^{188}$ Researchers have learned about the dopamine system from studying rodents willing

177 CARTER ET AL., THE HUMAN BRAIN, supra note 42, at 154-57; SWEENEY, supra note 44 , at $240-43$.

178 SWEENEY, supra note 44, at 239-40, 246.

179 CARTER ET AL., THE HUMAN BRAIN, supra note 42, at 159.

180 See MedinA, supra note 46, at 140-43; Daniel L. Schacter \& Anthony D. Wagner, Learning and Memory, in PRINCIPLES OF NEURAL SCIENCE, supra note 60, at 1441, 1448; see also SEUNG, supra note 64, at 79.

181 CARTER ET AL., THE HUMAN BRAIN, supra note 42, at 128.

182 Id.

183 Id.

184 Id.; PURVES ET AL., supra note 131, at 472.

185 MEYER \& QUENZER, supra note 165, at 250.

186 See id.

187 See DoIDGE, supra note 66, at 106. Dr. Arvid Carlsson of the University of Gothenburg in Sweden discovered dopamine as a neurotransmitter in 1957. He received the 2000 Nobel Prize for Medicine for his discovery. Vikram K. Yeragani et al., Arvid Carlsson, and the Story of Dopamine, 52 INDIAN J. PSYCH. 87, 87-88 (2010), http://www .ncbi.nlm.nih.gov/pmc/articles/PMC2824994/.

188 GIBB, supra note 38, at 176. 
to ignore food, breeding opportunities, and the needs of their offspring to self-stimulate their dopamine system using either electrodes or psychoactive drugs. ${ }^{189}$ Extensive parallel discoveries have been made in brain research conducted on rodents and humans; therefore, findings on the rodent dopamine system help to illuminate lawyer willingness to self-medicate with, or become addicted to, substances that activate the dopamine system. ${ }^{190}$

When falling glucose levels in a hungry and overworked lawyer create the desire to eat, that desire is registered in the specialized neurons in the emotional brain's ventral tegmental area (VTA) that produce dopamine. ${ }^{191}$ The VTA neurons have long axons that release dopamine in the thinking brain prefrontal cortex, responsible for planning, judgment, and reasoning. ${ }^{192}$ The VTA also releases dopamine in the emotional brain in nucleus accumbens (NAC, which is related to reward and pleasure); the amygdala (emotion); the dorsal striatum (habit learning); and hippocampus (memory processor). ${ }^{193}$ The NAC reacts by releasing an opioid-like peptide neurotransmitter in the VTA, forming a circuit. ${ }^{194}$ The dopamine system increases arousal, effort, and activity, and directs motivation toward acquiring an incentive - in this case a meal for the lawyer. ${ }^{195}$

If a lawyer is in the habit of eating a large salad while working through dinner, the restaurant near the office that prepares the salad has acquired strong motivational properties: incentive salience. ${ }^{196}$ The same is true if the lawyer has a cheeseburger, large french fries, and a huge soda to power through the project. Activation of the dopamine system will inspire the lawyer to call for takeout from somewhere. ${ }^{197}$ The food sources in the lawyer's environment have acquired incentive salience, causing the lawyer to notice and be attracted to them. ${ }^{198}$ When

\footnotetext{
189 LINDEN, supra note 164, at 20; Peter B. Shizgal \& Steven E. Hyman, Homeostasis, Motivation, and Addictive States, in PRINCIPLES OF NEURAL SCIENCE, supra note 60, at 1095, 1104.

190 LEDOUX, supra note 54, at 220; LINDEN, supra note 164, at 16; MEYER \& QUENZER, supra note 165 , at 248 .

191 William A McKim \& STEPHANIE D. HANCOCK, Drugs AND BeHAVIOR: AN INTRODUCTION TO BEHAVIORAL PHARMACOLOGY 115-19 (7th ed. 2013).

192 GIBB, supra note 38, at 176-77; LINDEN, supra note 164, at 16-18.

193 GIBB, supra note 38, at 176-77; HORSTMAN, DAY IN THE LIFE, supra note 36, at 77; LINDEN, supra note 164, at 16-18; SWEENEY, supra note 44, at 177.

194 MCKIM \& HANCOCK, supra note 191, at 115.

195 Id. at 115, 119; PURVES ET AL., supra note 131, at 471.

196 MEYER \& QUENZER, supra note 165, at 250.

197 MCKIM \& HANCOCK, supra note 191, at 116.

198 Id. at 119
} 
the lawyer consumes the meal, the VTA releases more dopamine in the NAC, and the source of the meal is registered in the thinking (cortex) and emotional (hippocampus) memory loop. ${ }^{199}$ Future late nights at the office will prompt dopamine activation and thus another take out call to the restaurant. ${ }^{200}$ If the lawyer walks by the restaurant on the way to a meeting, but is not hungry at the time, the dopamine system will be activated due solely to the restaurant's incentive salience. ${ }^{201}$

There is a difference in the reward system between wanting and liking various foods. Natural reinforcers cause the release of dopamine in the NAC. ${ }^{202}$ Rewards that improve fitness, including food and water, are primary or unconditioned reinforcers. ${ }^{203}$ The dopamine system exists to make the lawyer repeat behavior - to want to acquire certain foods, rather than to produce pleasure. ${ }^{204}$ People who suffer from Parkinson's disease have a dopamine deficiency, yet they do not report experiencing less pleasure than others when eating sweet foods. ${ }^{205}$ Increasing dopamine in the NAC of Parkinson's patients does not increase pleasure. ${ }^{206} \mathrm{~A}$ study on experienced cocaine users, where participants had their dopamine depleted, resulted in less craving (wanting) for cocaine, but no reduction in cocaine-induced euphoria (pleasure). ${ }^{207}$

Researchers have identified tiny hedonic hotspots in the NAC and ventral pallidum where activation enhances pleasure and where hotspot damage causes displeasure. ${ }^{208}$ The pleasure reactions in these hotspots are not dependent on dopamine. ${ }^{209}$ Liking reactions or euphoria are amplified when hedonic hotspots are stimulated by opioids, endocannabinoids, or GABA. ${ }^{210}$ In rodents, delivery of opioids and endocannabinoids to the hotspots increases facial responses that

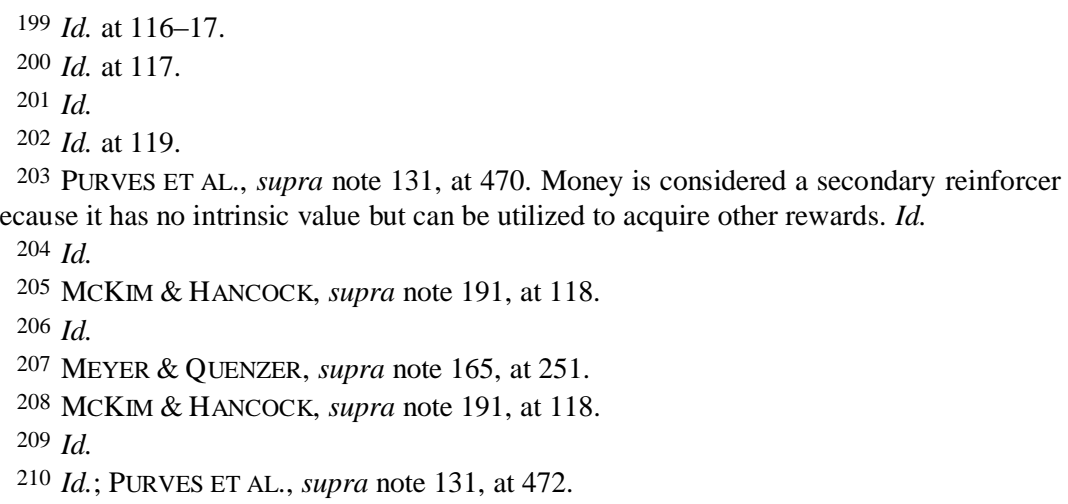


indicate pleasure derived from sweet foods. ${ }^{211}$ Because the lawyer brain produces naturally occurring opioids and endocannabinoids, those substances are likely responsible for the pleasure experienced in the lawyer brain hotspots, while dopamine appears responsible for the motivation necessary to acquire rewards and to trigger repeat behaviors. $^{212}$

The broadest definition of the word drug is "any substance that alters the physiology of the body," which includes food. ${ }^{213}$ Lawyers suffer from high rates of anxiety and depression, and while some may use antidepressants, others may self-medicate with food. ${ }^{214}$ In one study, ninety-seven percent of women and sixty-eight percent of men detailed experiencing food cravings. ${ }^{215}$ Overindulging with food can be a type of substance misuse. ${ }^{216}$

Over 100 studies found that during the digestion of excess sugar and fats, humans generate endogenous opioids. ${ }^{217}$ Meat, cheese, chocolate, and sucrose from sugar cane or sugar beets all stimulate the release of dopamine and endogenous opioids in the lawyer brain, making them foods at risk of becoming addictive. ${ }^{218}$ Research on animals has shown that intense sweetness from either sugar or artificial sweeteners outperforms cocaine as a desirable reward. ${ }^{219}$ Every dose of a problem food delivers a dopamine hit to the brain and reinforces a future desire for more. ${ }^{220}$ Foods with addictive potential include sweets, artificial sweeteners, carbohydrates, fats, sweet/fat combinations, and caffeine. ${ }^{221}$

Making good food decisions is challenging. It takes as much brain processing power to make inconsequential decisions as it does to make

211 MCKIM \& HANCOCK, supra note 191, at 118-19; MEYER \& QUENZER, supra note 165 , at 251.

212 MCKiM \& HANCOCK, supra note 191, at 119; Kyle S. Smith et al., Ventral Pallidum Roles in Reward and Motivation, 196 BEHAV. BRAIN RES. 155, 158 (2009).

213 MCKIM \& HANCOCK, supra note 191, at 1.

214 See LEVIT \& LINDER, supra note 127, at 6; MCCLURG, supra note 127, at 315-17;

Krieger, supra note 127, at 113-15; and Rosen, supra note 127, at 161.

215 LEYSE-WALLACE, supra note 25, at 164.

216 Id. at 14.

217 Id.

218 NEAL D. BARNARD, POWER FoOdS FOR THE BRAIN 49, 181-83 (1st ed. 2013).

219 LEYSE-WALLACE, supra note 25, at 14.

220 BARNARD, supra note 218, at 189.

221 LEYSE-WALLACE, supra note 25, at 14. 
important decisions. ${ }^{222}$ Processing a lot of data and making many small decisions causes brain cells to utilize glucose for energy and can produce decision-fatigue. ${ }^{223}$ "Without an adequate intake of all the required essential nutrients, the brain simply cannot function normally."224

\section{II}

\section{NEURO-DESTRUCTIVE CONDITIONS}

\section{A. Aging and Neurodegenerative Diseases}

\section{Aging}

Aging is a universal feature of being human. The growing population of Americans age sixty-five or older was $14.4 \%$ in 2013 , representing one in every seven, and is projected to rise to $21.7 \%$ by 2040. ${ }^{225}$ "Aging may be defined as a progressive postmaturational decline in physiological functions, accompanied by an increased susceptibility to disease and mortality risk." ${ }^{226}$ In 2006, sixty-two percent of 1000 Americans surveyed reported greater fear of losing mental capacity than a degradation of physical function. ${ }^{227}$ Cognition integrates complex mental processes such as consciousness, attention, knowledge acquisition, memory, and intelligence. ${ }^{228}$ These processes depend on synaptic transmission between neurons. ${ }^{229}$ Normal aging causes a decrease in the speed of synaptic signaling, which results in declines in learning, recall, and multitasking skills. ${ }^{230}$ Cognitive deficits are likely caused by age-related reduction in the volume of brain structures (hippocampus, prefrontal areas, basal forebrain,

222 Susie East \& Ben Tinker, How to Think Straight in the Age of Information Overload, CNN (Oct. 9, 2015, 8:18 AM), http://www.cnn.com/2015/10/09/health/information-over load-daniel-levitin/index.html.

223 Id.

224 LEYSE-WALlaCE, supra note 25, at 216 (quoting Scottish Neuroendocrinologist David Horrobin, MD).

225 Aging Statistics, Admin. FOR CMTY. Living, U.S. DEP'T HEAlth AND Human SERVS., http://www.aoa.acl.gov/Aging_Statistics/index.aspx (last visited Mar. 28, 2017).

226 Kanti Bhooshan Pandey \& Syed Ibrahim Rizvi, Role of Diet and Exercise in Intervention of Age-Induced Impairments, in DIET AND EXERCISE IN COGNITIVE FUNCTION AND NEUROLOGICAL DisEASES 1, 4 (Farooqui \& Farooqui eds., 2015).

227 LEYSE-WALLACE, supra note 25 , at 75.

228 Andreeva \& Kesse-Guyot, supra note 12, at 14.

229 Id.

$230 I d$. 
cerebellum, and caudate nucleus of the basal ganglia), decrease in the number of synapses, and compromised integrity of white matter. ${ }^{231}$

\section{Mild Cognitive Impairment, Dementia, and Alzheimer's Disease}

With aging comes the prospect of "losing one's mind" to impaired cognition ranging from mild cognitive impairment to dementia and finally Alzheimer's disease. ${ }^{232}$ A lawyer with mild cognitive impairment experiences a small amount of cognitive loss, such as slight decline in recall that does not interfere with daily activities. ${ }^{233}$ This lawyer has an increased risk of dementia. ${ }^{234}$ Dementia involves a marked and irreversible cognitive decline severe enough to mar daily life, which includes impairment in executive function, attention, concentration, and memory. ${ }^{235}$ Executive functions include thoughtful processing, initiating body movement, and the automated processing of information. ${ }^{236}$ Decision making is an executive function that requires creating and adapting rules for behavior and applying the appropriate rule for the environment. ${ }^{237}$ Executive function relies on a distributed network of brain regions in the thinking brain (parietal cortex, anterior cingulate cortex, basal ganglia) and the emotional brain (thalamus, hippocampus, amygdala, VTA). ${ }^{238}$ Episodic (autobiographical) memory decline is associated with hippocampi deterioration, mainly in the left hemisphere. ${ }^{239}$ Approximately $1.5 \%$ of sixty-five year olds and nearly twenty-five percent of eighty-five year olds in Western Europe, with similar rates in the United States, experience dementia. ${ }^{240}$

The most common cause of dementia, for nearly seventy percent of elderly patients, is Alzheimer's disease. ${ }^{241}$ Alzheimer's has two key features in the brain: increased extracellular amyloid plaque deposits and intracellular neurofibrillary tangles. ${ }^{242}$ These brain insults,

231 Id.; Edwin D. Lephart, Polyphenols and Cognitive Function, in NUTRITION FOR BRAIN HeAlTH AND COGNITIVE PERFORMANCE 145 (2015); LEYSE-WALlaCE, supra note 25 , at 88 .

232 See Best \& Dye, supra note 17, at 4.

233 Andreeva \& Kesse-Guyot, supra note 12, at 14.

234 Id.

235 Andreeva \& Kesse-Guyot, supra note 12, at 14-15.

236 PURVES ET AL., supra note 131, at 429.

237 Id. at 431.

238 Id. at $429,434-35$.

239 Id. at 15.

240 Best \& Dye, supra note 17, at 4.

241 Andreeva \& Kesse-Guyot, supra note 12, at 15.

242 Id. 
associated with increased inflammation and oxidative stress, cause neurodegeneration. ${ }^{243}$ Cognitive decline can be experienced for over a decade prior to the Alzheimer's diagnosis, highlighting the long and slow progression of Alzheimer's disease. ${ }^{244}$ Imaging studies show a loss of neurons (brain cells) in the basal forebrain and hippocampus of Alzheimer's patients. ${ }^{245}$

\section{Cardiovascular Disease}

Cardiovascular disease includes heart disease and strokes and is caused by inadequate blood supply to the heart and brain. ${ }^{246}$ When blood flow to the heart is disrupted, the result is often a heart attack, and twenty-five percent of people do not survive their first heart attack. ${ }^{247}$ If blood flow to the brain is interrupted for a sufficient period of time, a stroke occurs and part of the brain dies. ${ }^{248}$ It is normal for blood clots to form and break down in blood vessels, but the combination of normal clotting and plaque buildup in the arteries can cause obstructions in the coronary arteries, limiting blood supply to the heart, or blockages in the carotid arteries, diminishing blood supply to the brain. ${ }^{249}$ The amount of harmful LDL cholesterol present in the blood, which has been altered by free radicals into oxidized LDL, is directly related to the plaque buildup in cardiovascular disease. ${ }^{250}$

\section{B. Physical Conditions}

\section{Weight and Obesity}

The Centers for Disease Control and Prevention report that more than one-third of the adults in the United States are obese. ${ }^{251}$ Obesity

243 Id.

244 Id.

245 Lephart, supra note 231, at 144-45.

246 SMITH AND COLLENE, supra note 5, at 189.

247 Id.

248 SMITH \& COLLENE, supra note 5, at 189.

249 Id. at 190.

250 Id.

251 Adult Obesity Facts, CTRS. FOR DiSEASE CONTROL AND PREVENTION, http://www .cdc.gov/obesity/data/adult.html (last visited Mar. 28, 2017). Seventeen percent of the youth population is also obese. CYNTHIA OGDEN ET AL., JOURNAL OF THE AMERICAN MEDICAL ASSOCIATION, PREVALENCE OF CHILDHOOD AND ADULT OBESITY IN THE UNITED STATES, 2011-2012 (Feb. 26, 2014), http://jama.jamanetwork.com/article.aspx ?articleid=1832542). 
increases the risk of heart disease, diabetes, and cancer. ${ }^{252}$ Obesity is determined by Body Mass Index (BMI), and the ranges include: a normal BMI from 18.5 to < 25; overweight is a BMI of 25 to < 30 ; and the obese range is a BMI of 30 and higher. ${ }^{253} \mathrm{BMI}$ can be calculated by inputting height and weight into an online BMI calculator. ${ }^{254}$

Overconsumption of food can be compared to addiction to substances of abuse, but research on the human diet is complex because it is unethical to severely limit humans to specific diets in the same way scientists can place limits on the diets of research animals. ${ }^{255}$ Processed foods are developed to be hyperpalatable to overstimulate the brain's reward system. They are not comparable to the foods humans evolved to eat. ${ }^{256}$ The desire to overconsume food is influenced by the dopamine system, which inspires repeat behavior. ${ }^{257}$ Hyperpalatable food triggers the release of endogenous opioid and endocannabinoids, which creates the sensation of pleasure. ${ }^{258}$

To ensure survival, humans evolved to favor foods that are high in fat and sugar. Highly processed foods contain such great quantities of fat and sugar, they create the potential for abuse similar to the misuse of drugs like alcohol or cocaine. ${ }^{259}$ Addictions are "unusually strong and maladaptive desires to ingest a substance or engage in a behavior despite negative consequences." 260 The same genetic and personality traits commonly found in human addiction to substances are also linked to binge eating disorders and obesity. ${ }^{261}$ Research findings using rats exposed to large amounts of fat and sugar can be applied to humans because of the similarities in their omnivorous diets, brain reward

252 The State of Obesity 2015, TRUST FOR AM. HEALTH (Sept. 2015), http://healthy americans.org/reports/stateofobesity2015/.

253 Defining Adult Overweight and Obesity, CTRS. FOR DISEASE CONTROL AND PREVENTION, http://jama.jamanetwork.com/article.aspx ?articleid=1832542 (last visited Mar. 28, 2017).

254 Adult BMI Calculator, CTRS. FOR DISEASE CONTROL AND PREVENTION, http://www.cdc.gov/healthyweight/assessing/bmi/adult_bmi/english_bmi_calculator/bmi _calculator.html (last visited Mar. 28, 2017).

255 Heather M. Francis \& Richard J. Stevenson, The Effect of Western Diet on Cognition in Humans, in DIET AND EXERCISE IN COGNITIVE FUNCTION AND NEUROLOGICAL DISEASES 114-15 (Farooqui \& Farooqui eds., 2015).

256 Francis \& Stevenson, supra note 255, at 115.

257 Id. at 114

258 Francis \& Stevenson, supra note 255, at 115.

259 ASHLEy N. GEARHARDT ET AL., THE AdDiCTION POTENTIAL OF HyPERPALATABLE FoOdS, 4(3) CURRENT DRUG ABUSE REVS., at 140-42 (2011).

260 GEARHARDT ET AL., supra note 259, at 141.

261 Id. at 140 
systems, and drug addiction characteristics (motivation, tolerance, continued use despite negative consequences, and withdrawal). ${ }^{262}$ Recent animal research indicates that exposure to a high-fat diet during pregnancy alters dopamine and opioid gene expression and causes a preference for hyperpalatable food in offspring. ${ }^{263}$

In the twenty-first century, the nutrition paradox describes the societal condition where obesity coexists with malnutrition and vitamin deficiencies. ${ }^{264}$ This is likely due to the impact of the industrial revolution on the food industry and the processing of plant substances into highly concentrated additives, which are quickly absorbed into the blood stream - very rewarding, and thus addictive. ${ }^{265}$

Corn is a food that has been consumed by humans for centuries, but refining it into high fructose corn syrup creates a sweet, concentrated simple carbohydrate not found in nature. ${ }^{266}$ Fructose and alcohol share very similar addictive properties, and alcohol is the fermented byproduct of fructose. ${ }^{267}$ Excessive consumption of both alcohol and high fructose corn syrup can cause a down-regulation of the dopamine system triggering cravings, increased intake, and withdrawal symptoms when use is suspended. ${ }^{268}$ Consumption of high levels of fructose promotes insulin resistance and reduces leptin signaling creating sensations of hunger despite energy needs, therefore promoting overconsumption. ${ }^{269}$

Hyperpalatable foods often contain high fructose corn syrup in combination with other additives such as fat, salt, flavor enhancers, and other sweeteners, all of which serve to intensify the rewarding property of these highly-processed foods. ${ }^{270}$ Overconsumption of hyperpalatable foods causes high calorie intake combined with low nutrient value, increased portion sizes, elevated tolerance to overconsumption, and disruption of the dopamine system. ${ }^{271}$ In addition to altering the motivation and reward system in the brain,

262 GEARHARDT ET AL., supra note 259, at 140-41.

263 Id. at 143-44.

264 Best \& Dye, supra note 17, at 7.

265 GEARHARDT ET AL., supra note 259, at 141.

266 Id.

267 GEARHARDT ET AL., supra note 259, at 141 (noting that alcohol is also known as ethanol).

268 Id.

269 Id. at $141-42$.

270 Id. at 142 .

271 Id. 
overeating and weight gain cause damage to the hippocampus in rodent studies. ${ }^{272}$ Like drug users, overeaters eventually experience increased cravings for hyperpalatable foods (wanting) without the pleasurable reward (liking), thus addiction to food is extremely similar to addiction to drugs of abuse. ${ }^{273}$ Individuals who are concerned about food addiction can download the Yale Food Addiction Scale and Scoring Sheet and assess their risk. ${ }^{274}$ Applying an addiction perspective to weight and obesity problems should assist lawyers in understanding why weight loss is so difficult and inform public policy on healthy diet practices, the impact of inexpensive hyperpalatable foods on underprivileged populations, and the goal of limiting food additives, just as drugs of abuse have been curbed in Western society. ${ }^{275}$

\section{Blood Sugar, Insulin Resistance, and Glycation}

All carbohydrates are broken down into glucose, which is the substance that is tested for blood sugar. ${ }^{276}$ Glucose is the energy source for the body's brain cells, and insulin unlocks the cells so the glucose can enter. ${ }^{277}$ The ideal meal allows blood sugar and insulin to rise and recede gradually. ${ }^{278}$ Consumption of simple sugars causes a spike in blood sugar and a flood of insulin. ${ }^{279}$ Excess insulin causes a body to use glucose for energy all the time, rather than burning fat, which makes weight control very challenging. ${ }^{280}$ Routinely eating simple sugars creates a demand for more insulin to normalize blood sugar, and eventually that body becomes insulin resistant, which gives way to diabetes. ${ }^{281}$

Type 2 diabetes is often associated with cognitive impairment, and a study of fifty to ninety year olds found that both insulin-dependent and non-insulin-dependent diabetics scored lower on cognitive tests of

272 Akhlaq A. Farooqui \& Tahira Farooqui, Neurochemical Effects of Western Diet Consumption on Human Brain, in DIET AND EXERCISE IN COGNITIVE FUNCTION AND NEUROLOGICAL DisEASES 15, 19 (Farooqui \& Farooqui eds., 2015).

273 GEARHARDT ET AL., supra note 259, at 142-43.

274 Ashley N. Gearhardt, William R. Corbin \& Kelly D. Brownell, Yale Food Addiction Scale, MeASurement InStRument DataBASE FOR THE SOC. SCIS. (2009), http://www .midss.org/content/yale-food-addiction-scale-yfas.

275 GEARHARDT ET AL., supra note 259, at 143-44.

276 BHATIA, supra note 8 , at 18 .

277 Id.

278 Id. at 18-19.

279 Id. at 19.

$280 \mathrm{Id}$.

281 Id. 
intellectual ability and verbal memory than control participants. ${ }^{282}$ Early detection of diabetes risk and effective diabetes treatment may prevent or delay this cognitive decline. ${ }^{283}$

Consumption of high-sugar snacks and meals results in short-term attention and memory problems in healthy adults and children. ${ }^{284}$ Rats exposed to long-term high-sugar diets exhibit learning and memory deficits. ${ }^{285}$ Consistent intake of high-sugar foods maintains high blood glucose levels and increases the risk of glycation. ${ }^{286}$

Glycation is a normal progression where glucose reacts with protein in the body to form glucose-protein molecules called advanced glycation end products (AGEs). ${ }^{287}$ AGEs are debris that are resistant to the body's restorative processes, and their formation is irreversible. ${ }^{288}$ AGEs are responsible for inflammation, aging, joint stiffness, kidney problems, cataracts, plaque buildup and hardening of arteries, and compromised brain cells and neuron connections. ${ }^{289}$ In Alzheimer's patients, there are triple the number of AGEs than in normal brains, and they are accumulated in the amyloid plaques and neurofibrillary tangles. ${ }^{290}$

Elevated blood sugar creates more AGEs than normal, accelerating aging. ${ }^{291}$ Carbohydrates cause AGEs to form, and foods that create the largest spike in blood sugar trigger the greatest AGE formation. ${ }^{292}$ Foods that contain the highest levels of preformed AGEs are meat and cheese; cured meats (e.g., bacon, sausage, pepperoni, and hot dogs) and meats cooked at high temperatures (like by frying or broiling) represent the highest risk. ${ }^{293}$

\footnotetext{
282 LEYSE-WALLACE, supra note 25 , at 87.

283 Id.

284 Francis \& Stevenson, supra note 255, at 112.

285 Id.

286 William DAVIS, WHEAT Belly: LOSE THE WHEAT, LOSE THE WEIGHT, AND FIND YOUR PATH BACK TO HEALTH 133-35 (2011).

287 DAVIS, supra note 286, at 133-34; Farooqui \& Farooqui, supra note 272, at 20.

288 DAVIS, supra note 286 , at $133-35$.


UPGRADE YOUR BRAIN, UPGRADE YOUR LIFE 87 (2015).

290 DAVIS, supra note 286, at 136.

291 Id. at 135-37.

292 Id. at 140

293 DAVIS, supra note 286, at 140-41; CORTRIGHT, supra note 289, at 89.
} 
Reducing AGE exposure promotes good health and longevity, especially since hemoglobin glycation is irreversible. ${ }^{294}$ The HbA1c blood test evaluates AGE formation by determining glycation rate. ${ }^{295}$ A lawyer with a low or normal BMI who limits carbs will have 4.0 to $4.8 \%$ of all hemoglobin glycated, expressed on the HbA1c test result as a range of 4.0 to $4.8 .^{296}$ Normal HbAlc range is 5.0 to 6.4 and the diabetes threshold is 6.5 , although some diabetics have eight to twelve percent glycated hemoglobin. ${ }^{297}$ About seventy percent of Americans have $\mathrm{HbA} 1 \mathrm{c}$ levels between 5.0 and 6.9, and for every one percent $\mathrm{HbA1c}$ increase there is a twenty-eight percent increased risk of death. ${ }^{298}$

While all carbs raise blood sugar, wheat products skyrocket blood sugar to near diabetic levels. ${ }^{299}$ Wheat constitutes about twenty percent of all calories consumed worldwide and is second only to corn in farmland planted. ${ }^{300}$ Fifty years of genetic engineering have increased the wheat crop yield and created new gluten proteins. ${ }^{301}$ Hybridization of wheat has produced a supercarb made up of seventy-five percent amylopectin $\mathrm{A}$, the most digestible form of amylopectin, giving wheat bread the power to raise blood glucose more than table sugar. ${ }^{302}$ The startling consequence of modern engineered wheat is that wheat products raise blood sugar higher than nearly every other carbohydrate. ${ }^{303}$ Consumption of wheat products triggers high insulin levels, greater fat deposits, inflammation, and a hunger cycle that features fatigue and mental fog when blood sugar drops. ${ }^{304}$

Lawyers seeking to lower blood sugar should consider reducing wheat products. Giving up wheat could be very challenging for some people because wheat polypeptides (also called exorphins) bind to opiate receptors in the brain. ${ }^{305}$ Scientists know this because in research animals, naloxone, the drug that knocks opiates off their receptors and blocks their action also prevents the effects of wheat-

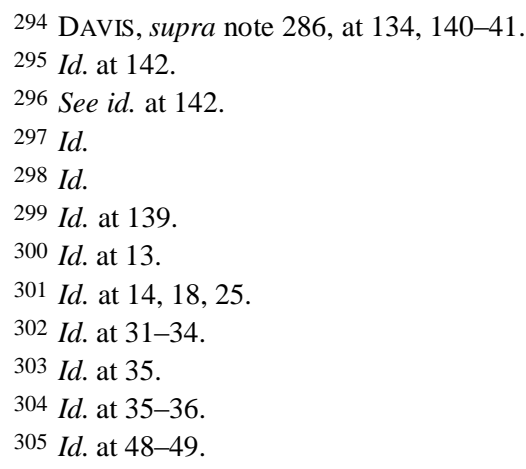


derived exorphins. ${ }^{306}$ In humans, naloxone reduces food cravings, appetite, and calorie consumption. ${ }^{307}$ Decreasing consumption of high Glycemic Index carbs and preformed AGEs (cured meats, cheese, and meats cooked at high temperatures) will help stave off rising glycation HbA1c numbers. ${ }^{308}$ Controlling AGE formation is also important because high levels of AGEs lead to greater inflammation and oxidative stress. ${ }^{309}$

\section{Inflammation}

Inflammation is the body's normal immune response to injury or germs. ${ }^{310}$ Inflammation often increases with age. ${ }^{311}$ Low-grade chronic inflammation is at the root of heart disease, diabetes, cancer, autoimmune diseases, and contributes to depression and cognitive deterioration. $^{312}$

Inflammation is triggered by being overweight, consuming highcaloric meals, and eating the Western Diet, including a high intake of processed foods, refined carbohydrates, and bad fats (animal fat; trans fats; and corn, safflower, sunflower, and sesame oils). ${ }^{313}$ Other factors that cause inflammation are stress, inadequate sleep, insufficient physical activity, and Vitamin D deficiency. ${ }^{314}$

Reducing inflammation has been correlated with memory improvement. $^{315}$ The first steps a lawyer can take to reduce inflammation are to control stress and limit sugar intake. ${ }^{316}$ Diets rich in Omega-3 fatty acids and fruits and vegetables, which are high in

306 Id. at 49.

307 Id. at 51.

308 Id. at 140-41; CORTRIGHT, supra note 289, at 89.

309 DAVIS, supra note 286, at 138.

310 BHATIA, supra note 8, at 19-20.

311 Andreeva \& Kesse-Guyot, supra note 12, at 26.

312 BHATIA, supra note 8, at 20; LESLIE KORN, NUTRITION ESSENTIALS FOR MENTAL HEALTH: A COMPLETE GUIDE TO THE FOOD-MOOD CONNECTION 3 (2016).

313 BHATIA, supra note 8, at 20; KoRN, supra note 312, at 2.

314 KORN, supra note 312 , at 3.

315 Andreeva \& Kesse-Guyot, supra note 12, at 26.

316 KORN, supra note 312, at 3-4. 
antioxidants, decrease inflammation. ${ }^{317}$ Regular exercise also reduces inflammation. ${ }^{318}$

\section{Oxidative Stress}

Alzheimer's disease involves both inflammation and oxidation, but researchers do not know whether these conditions are a cause or an effect. ${ }^{319}$ One theory of brain aging posits that the brain suffers from the progressive inability to prevent inflammation and oxidative stress. $^{320}$

Oxidation is the process in which atoms and molecules lose electrons as they touch other atoms and molecules. ${ }^{321}$ Car rust and the browning of cut fruit are examples of oxidation. ${ }^{322}$ Oxidation is beneficial when it facilitates energy transfer or transforms harmful substances into water-soluble waste that is eliminated during urination. ${ }^{323}$

Excess oxidation creates free radicals that hasten aging, stimulate cancer, and rupture plaques which can cause heart attacks and strokes. ${ }^{324}$ Extensive metabolic activity and production of free radicals occur in the brain. ${ }^{325}$ The brain is highly susceptible to oxidative stress due to its high metabolic load and rate of oxygen consumption. ${ }^{326}$ The plasma membranes of neurons are made up of long-chain fatty acids (DHA), which are highly oxidizable. ${ }^{327}$ Thus, the phospholipids in neuron membranes are vulnerable to damage from free radicals. ${ }^{328}$ The generation of free radicals is a normal part of human metabolism, but surplus free radicals lead to interference of neuron functioning, disruption of signaling, and brain cell death. ${ }^{329}$ A meta-analysis of the research on the presence of oxidative stress in psychiatric disorders

\footnotetext{
317 Andreeva \& Kesse-Guyot, supra note 12, at 26; Adrian L. Lopresti, Contribution of Diet and Exercise in the Pathogenesis of Major Depression, in DIET AND EXERCISE IN Cognitive Function AND Neurological Diseases 96-97 (Farooqui \& Farooqui eds., 2015).

318 Lopresti, supra note 317, at 99.

319 LEYSE-WALLACE, supra note 25, at 89.

320 Andreeva \& Kesse-Guyot, supra note 12, at 30.

321 THE CHINA STUDY, supra note 9 , at 9.

322 Id.

$323 \mathrm{Id}$.

324 Id.

325 LEYSE-WALLACE, supra note 25, at 89.

326 Andreeva \& Kesse-Guyot, supra note 12, at 27.

327 Id.

328 LEYSE-WALLACE, supra note 25, at 97, 190.

329 Id. at 89.
} 
concluded that the majority of those disorders are associated with increased oxidation. ${ }^{330}$

High-protein diets may promote free radical production. ${ }^{331}$ Plants produce free radicals during photosynthesis, but plants also contain antioxidants, which bind to and neutralize free radicals. ${ }^{332}$ When lawyers eat plants with antioxidants, they are protected against free radicals, while beneficial oxidation is left unaffected. ${ }^{333}$ Antioxidants protect against free radical damage to neurons. ${ }^{334}$ The following nutrients have been shown to reduce oxidative stress and improve cognitive performance: Vitamin C, Vitamin E, DHA, beta-Carotene, and selenium. ${ }^{335}$ Animals that are fed antioxidants have superior learning capacity and memory retention. ${ }^{336}$ Other foods rich in antioxidants are listed in Part V.

\section{Metals and Oxidation}

Copper, iron, and zinc are metals that are needed by the body but, in excess, can harm brain cells and accelerate aging. ${ }^{337}$ These metals form free radicals, the highly unstable and destructive oxygen molecules that attack healthy cells. ${ }^{338}$ People with less copper and iron in their blood have fewer memory and cognitive difficulties. ${ }^{339}$ Excess copper impairs attention, learning, and memory. ${ }^{340}$ Surplus or insufficient iron levels cause cognitive impairment. ${ }^{341}$ Research indicates that people who consume unhealthy fats (saturated fat or partially hydrogenated oils) in combination with excess copper have the cognitive function of people nineteen years older than their chronological age. ${ }^{342}$

Copper, iron, and zinc are also found in the beta-amyloid plaques of patients with Alzheimer's disease. ${ }^{343}$ Copper and iron promote the

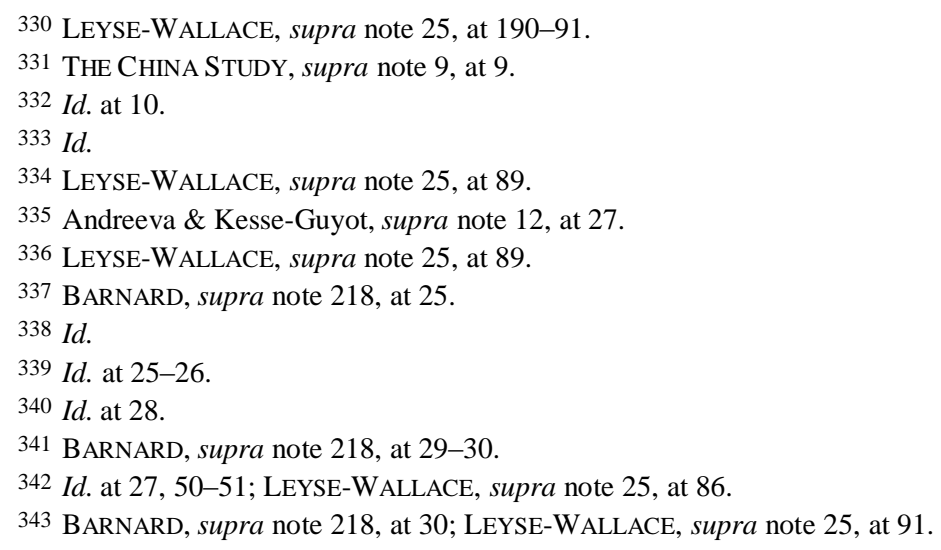


creation of free radicals, and zinc causes beta-amyloid proteins to bunch together to form plaques. ${ }^{344}$ Potentially harmful amounts of copper and iron are ingested from copper plumbing, cookware, fortified cereals, meats, and supplements that contain minerals. ${ }^{345}$ Plants contain nonheme iron, which has the equilibrium-promoting feature of providing needed iron to the brain and body while limiting excess. ${ }^{346}$ Phytic acid in plants also limits the amount of copper and zinc a lawyer's body absorbs. ${ }^{347}$ Exercise and donating blood help rid the body of excess iron. ${ }^{348}$

Aluminum, a metal that offers no nutritional value, has been found in the brains of patients suffering from Alzheimer's disease. ${ }^{349}$ Researchers disagree about whether a causal relationship exists, but regardless, aluminum is considered a neurotoxin. ${ }^{350}$ Since there is no benefit to ingesting aluminum, avoid it in cookware, soda cans, foil, frozen pizza cheese, pickle relish, single-serving creamers and salt packets, and choose aluminum-free baking powder, antacids, and antiperspirants. ${ }^{351}$

Table 1. Metal Amounts Needed Daily ${ }^{352}$

\begin{tabular}{|l|l|l|}
\hline Metals & Recommended Daily & \multicolumn{1}{c|}{ Sources } \\
\hline Copper & $.09 \mathrm{mg}$ & $\begin{array}{l}\text { Beans, leafy green vegetables, } \\
\text { nuts, whole grains, and } \\
\text { mushrooms. }\end{array}$ \\
\hline Iron & $\begin{array}{l}8 \mathrm{mg} \text { adults over } 50 \\
18 \mathrm{mg} \text { adults } 19 \text { to } 50\end{array}$ & $\begin{array}{l}\text { Leafy green vegetables, nuts, } \\
\text { whole grains, and dried fruits. }\end{array}$ \\
\hline Zinc & $\begin{array}{l}8 \mathrm{mg} \text { for women } \\
11 \mathrm{mg} \text { for men }\end{array}$ & $\begin{array}{l}\text { Oatmeal, whole-grain bread, } \\
\text { brown rice, peanuts, beans, nuts, } \\
\text { peas, and sesame seeds. }\end{array}$ \\
\hline
\end{tabular}

\section{Emotional Conditions}

The World Health Organization defines mental health "as a state of well-being in which every individual realizes his or her own potential,

\footnotetext{
344 BARNARD, supra note 218 , at 30-31.

345 Id. at 31-34.

346 Id.

347 Id. at 35.

$348 I d$. at 43.

349 Id. at 36-38.

350 Id. at 39.

351 Id. at $39-42$.

$352 \mathrm{Id}$. at 36.
} 
can cope with the normal stresses of life, can work productively and fruitfully, and is able to make a contribution to her or his community." "353 Two types of psychological well-being are hedonic (short-term pleasures evoked by the senses) and eudaimonic (longerterm positive states such as feelings of satisfaction or gratitude). ${ }^{354} \mathrm{Six}$ components of eudaimonic well-being are autonomy, environmental mastery, self-acceptance, personal growth, purpose in life, and positive relationships with others. ${ }^{355}$

Emotion is an acute, specific perception, felt in response to an event. ${ }^{356}$ Mood, as defined by psychologists, is a positive or negative emotional state that varies in intensity, is modified in response to life's circumstances, and is often expressed in terms of valence ${ }^{357}$ and activation (feeling sleepy or awake, energized or fatigued). ${ }^{358}$

At any given time, a lawyer's mental status falls somewhere on a continuum between mental health and mental illness. ${ }^{359}$ A lawyer's nutritional status also rests on a continuum between optimal physical health and disease, and the totality of a lawyer's circumstances may be described as quality of life. ${ }^{360}$

\section{Stress}

Four of the six primary emotions are adverse: fear, anger, sadness, and disgust. ${ }^{361}$ Jeansok Kim and David Diamond derived a three-part test to describe stress: (1) there must be a physiological response to the stressor that is measurable by another person; (2) the stressor must be perceived as detrimental; and (3) there is a lack of control over the

353 Mental Health: A State of Well-Being, WorLd HEALTH ORG., http://www.who.int /features/factfiles/mental_health/en/ (last updated Aug. 2014).

354 LEYSE-WALLACE, supra note 25, at 186.

355 Id.

356 Maria A. Polak et al., Measuring Mood: Considerations and Innovations for Nutrition Science, in NUTRITION FOR BRAIN HEALTH AND COGNITIVE PERFORMANCE 96-97 (2015).

357 Valence, WEBSTER's THIRD NEW INTERNATIONAL DictionaRy (3d ed. 1986) (defining valence as "the degree of attractiveness an individual, activity, or object possesses as a behavioral goal").

358 Polak et al., supra note 356, at 96-97.

359 LEYSE-WALLACE, supra note 25 , at xxvi.

360 Id. at Xxvi-xxvii.

361 CARTER ET AL., THE HUMAN BRAIN, supra note 42, at 127; SWEENEY, supra note 44, at 208. 
stressor. ${ }^{362}$ Stress has also been defined as the perception that demands exceed the physical and mental resources available to address them. ${ }^{363}$

Stress may result in some combination of irritability, anxiety, anger, and depression. ${ }^{364}$ Law students are more than twice as likely as other students to be diagnosed with anxiety, and lawyers suffer from depression at rates 3.6 times higher than other employed adults. ${ }^{365}$ Lawyers suffer from serious well-being problems in addition to anxiety and depression (suicide risk, substance abuse, and mental illness), ${ }^{366}$ but they do not exhibit these disorders prior to law school. ${ }^{367}$

The fight-or-flight stress response was very helpful when humans needed to escape from predators, but it can be maladaptive in law school or law practice. ${ }^{368}$ Acute stress, the kind meant to help evade predators, is short lived and designed to marshal resources to deal with an intellectual or physical challenge. ${ }^{369}$ Chronic stress is long lasting and is experienced during life's most exacerbating demands. ${ }^{370}$ Longterm stress can cause irritability, anxiety, panic attacks, or depression, and the physical effects include breathlessness, dizziness, muscle tension, sweating, chills, abdominal discomfort, increased blood pressure, heart palpitations, and chest pain. ${ }^{371}$ Persistent stress response damages the lawyer body (impaired immune system, compromised digestive system, cardiovascular risk); mental state (anxiety, depression); and brain (hippocampus, amygdala) and impairs cognitive performance. ${ }^{372}$

362 See MEDINA, supra note 46, at 173-74.

363 LEYSE-WALLACE, supra note 25, at 189-90.

364 LEYSE-WALLACE, supra note 25, at 190.

365 Lekan Oguntoyinbo, Battling Mental Illness in the Legal Profession, DIVERSITY AND THE BAR, Apr. 2015, at 19; Martin E. P. Seligman, Why are Lawyers So Unhappy?, LAWYERS WITH DEPRESSION (Nov. 16, 2012), http://www.lawyerswithdepression.com /articles/why-are-lawyers-so-unhappy/.

366 Martin Seligman et al., Why Lawyers Are Unhappy, 23 CARdOzo L. REv. 33, 36-37 (2001).

367 Lawrence S. Krieger, Institutional Denial About the Dark Side of Law School, and Fresh Empirical Guidance for Constructively Breaking the Silence, 52 J. LEGAL EDUC. 112, 113-15 (2002).

368 See Gore, supra note 131, at 803; see SAPOLSKY, supra note 68, at 12.

369 PeRlmutTER \& Villoldo, supra note 49, at 59.

370 Id.; see LITOWITZ, supra note 127, at 10, 19.

371 See CARTER ET AL., THE HuMAN BRAIN, supra note 42, at 232.

372 Shawn Talbott, The Cortisol Connection: Why Stress MaKes You Fat AND Ruins Your Health-AND What You CAN Do ABout IT 22 (2007); HANSON, supra note 142, at 5260; RATEY, SPARK, supra note 60, at 67-71; see DEVI, supra note 141, at $83-86$. 
Researcher and cell biologist Bruce H. Lipton argues that when cells are subjected to the fight-or-flight stress response, they are less able to absorb nutrients because their response is to protect themselves by blocking access. ${ }^{373}$ The protect-and-defend condition constricts blood vessels in the digestive system and inhibits the immune system. ${ }^{374}$ People with gastrointestinal disorders are at higher risk for psychological illnesses than physical illnesses, and digestive system problems may compromise nutritional status by altering food selection, nutrient intake, and/or nutrient absorption. ${ }^{375}$

One theory gaining support on the impact of stress on the brain is that the suppression of neuron growth from exposure to stress hormones is the source of depression because the hippocampus (emotional brain) and prefrontal cortex (thinking brain) shrink in chronically depressed people. ${ }^{376}$

\section{Depression}

Depression is the leading cause of disability worldwide, more women suffer from depression than men, and depression puts people at risk of suicide. ${ }^{377}$ A landmark study conducted by the Hazelden Betty Ford Foundation and the American Bar Association Commission on Lawyer Assistance Programs had 12,825 licensed and employed lawyer participants and found twenty-three percent of attorneys were experiencing stress, nineteen percent had symptoms of anxiety, $20.6 \%$ were actively problem drinking, and twenty-eight percent were suffering from depression. ${ }^{378}$ Over the course of their legal careers, sixty-one percent of attorneys had experienced anxiety, forty-six percent had dealt with depression, and $11.5 \%$ had suicidal thoughts. ${ }^{379}$

\footnotetext{
373 LEYSE-WALLACE, supra note 25 , at 210-11.

$374 \mathrm{Id}$. at 211.

375 Id. at 192.

376 Id. at 211.

377 Depression Fact Sheet, WORLD HEALTH ORG., http://www.who.int/mediacentre /factsheets/fs369/en/ (last updated Feb. 2017) (stating that approximately 300 million people from around the world suffer from depression and over 800,000 people commit suicide each year).

378 Patrick Krill, Ryan Johnson \& Linda Albert, The Prevalence of Substance Use and Other Mental Health Concerns Among American Attorneys, J. OF ADDICTION MED. VOL. 10, Jan. Feb. 2016, at 46-51, http://journals.lww.com/journaladdictionmedicine/Fulltext /2016/02000/The_Prevalence_of_Substance_Use_and_Other_Mental.8.aspx. Men suffered from higher rates of depression, and women from anxiety and stress. $I d$. at 49 .

379 Id. at 50.
} 
According to the National Institute of Mental Health, symptoms of depression include difficulty with concentration, memory, and decision making; fatigue or low energy levels; feeling irritable, anxious, sad, pessimistic, hopeless, worthless, or helpless; decreased interest in or pleasure from activities or hobbies; sleep difficulties; appetite and/or weight changes; pain, digestive problems, and headaches without a clear physical cause that do not resolve with treatment; and/or suicidal thoughts or attempts. ${ }^{380}$

In 2013, suicide was the tenth leading cause of death for Americans of all ages, and there were 113 suicides each day, translating to one every thirteen minutes. ${ }^{381}$ Suicide rates have grown by sixty percent worldwide in the last forty-five years. ${ }^{382}$ According to the Centers for Disease Control and Prevention, lawyers rank fourth in suicide rates compared to other professions, preceded only by dentists, pharmacists, and doctors. ${ }^{383}$ Lawyers suffer from depression at rates 3.6 times higher than other employed adults, and depression is linked to risk of suicide. $^{384}$

Attorney Ken Jameson killed himself in 2011 at age fifty-eight, after a six-month bout of depression, despite generating a good income and a having strong marriage. ${ }^{385}$ In 2012, Finis Price III, a successful lawyer and popular professor at Chase Law School at Northern Kentucky University, jumped to his death at age thirty-seven. ${ }^{386}$ Lawyer Harry Rankin, fifty-eight, hanged himself while being treated for depression. ${ }^{387}$ Dave Nee was a well-loved law school graduate who took his own life while studying for the bar exam. ${ }^{388}$ In July 2014, Cheryl Hanna, a law professor at Vermont Law School, shot and killed herself with a handgun purchased the day before and soon after a nine-

380 Depression Definition, NAT'L InST. OF Mental Health, https://www.nimh.nih .gov/health/topics/depression/index.shtml (last visited Mar. 28, 2017).

381 Suicide: Facts at a Glance, CTRS. FOR DisEASE CONTROL AND PREVENTION (2015), http://www.cdc.gov/violenceprevention/pdf/suicide-datasheet-a.pdf.

382 LEYSE-WALLACE, supra note 25, at 125.

383 Rosa Flores \& Rose Marie Arce, Why Are Lawyers Killing Themselves, CNN (Jan. 20, 2014, 2:42 PM), http://www.cnn.com/2014/01/19/us/lawyer-suicides/.

384 Martin E. P. Seligman, Why are Lawyers So Unhappy?, LAWYERS WITH DEPRESSION (Nov. 16, 2012), http://www.lawyerswithdepression.com/articles/why-are-lawyers-so -unhappy/; Depression Fact Sheet, WORLD HEALTH ORG., http://www.who.int/media centre/factsheets/fs369/en/ (last updated Feb. 2017).

385 Flores \& Arce, supra note 383.

386 Id.

387 Id.

388 History, DAVE NEE FOUNDATION, http://www.daveneefoundation.org/history/ (last visited Mar. 28, 2017). 
day hospitalization for depression. ${ }^{389}$ A respected domestic violence scholar, Hanna had been worried that she would be stigmatized if her depression became public and that her adversaries would use her illness against her. ${ }^{390}$

Both neurogenesis (the birth of new brain cells in the hippocampus) and neuroplasticity are impaired in people suffering from depression. ${ }^{391}$ Research has discovered changes in the hippocampus and hypothalamus, as well as lower levels of BDNF, in depressed research participants. ${ }^{392}$

There is a relationship between diet and depression. Consumption of a Western diet increases the risk of depression, while the Mediterranean Diet is associated with a lower depression risk. ${ }^{393}$ Diet and depression have a bidirectional relationship: diet quality impacts depression symptoms and depression influences food selection. ${ }^{394}$ For example, the more calories, saturated fat, and salt eaten by college students, the poorer their mood two days later. ${ }^{395}$

Studies have shown that people with depression have low levels of folate (the supplement is known as folic acid), Vitamin $\mathrm{B}_{12}$, Vitamin D, and Omega-3, and high levels of plasma homocysteine. ${ }^{396}$ Depressed research participants have presented with lower levels of Vitamin $B_{6}$ and Vitamin $B_{12}$ than control participants. ${ }^{397}$ Approximately ten to twenty percent of people in their late sixties and older are $\mathrm{B}_{12}$ deficient, and vegetarians may be at risk for Vitamin $B_{12}$ deficiency. ${ }^{398}$ Affective symptoms of Vitamin $\mathrm{B}_{12}$ deficiency include irritability, mood swings, apathy, and sleepiness, and cognitive symptoms include concentration, memory problems, and sluggish thinking. ${ }^{399}$

Research indicates that populations with higher consumption of Omega-3 fatty acids experience lower rates of depression, and fatty acid analysis of red blood cells showed a significant depletion of

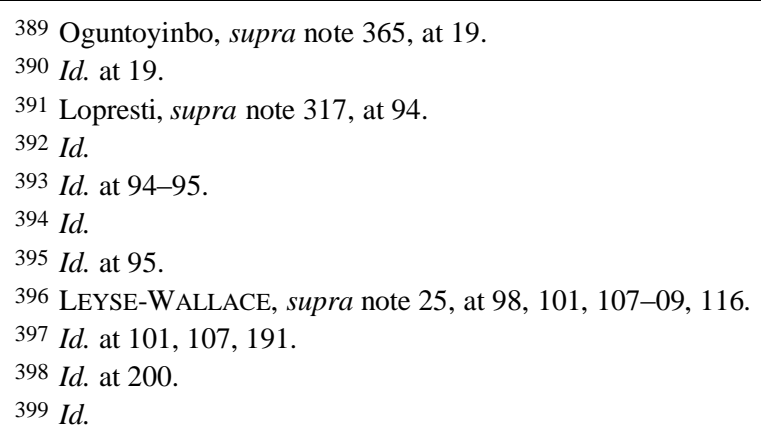


Omega-3 fatty acids in patients with depression. ${ }^{400}$ Research participants with depression have also shown higher ratios of Omega6 to Omega-3 than control participants. ${ }^{401}$ Elderly, depressed women who were treated with Omega-3 supplements showed a significant decrease in depression symptoms and a significant improvement in their quality of life. ${ }^{402}$ Ethyl-eicosapentaenoate (EPA) supplementation has been shown to decrease depression symptoms including anxiety, fatigue, sleep problems, libido issues, and suicidality. ${ }^{403}$

III

NUTRITION

Let food be thy medicine and medicine be thy food.

-Hippocrates ${ }^{404}$

Ancient Indian and Chinese healers, and Hippocrates, the father of modern medicine, believed good health could be achieved with the appropriate diet. ${ }^{405}$ Medicine moved away from nutrition-based recommendations with the scientific discoveries of the Industrial Revolution. ${ }^{406}$ In the mid-1980s, medical education returned nutrition to the curriculum, and about two-thirds of American medical schools currently incorporate nutrition courses. ${ }^{407}$ Nutrition is a modifiable lifestyle element that can support brain health and improve cognitive function. ${ }^{408}$

\footnotetext{
$400 I d$. at 98.

$401 \mathrm{Id}$. at 101.

402 Id. at 102.

403 Id. at 100 .

404 BHATIA, supra note 8 , at 10 .

405 Id. at 7.

406 Id. at 8 (noting that medical advances include pasteurization, vaccinations, antibiotics, anesthesia, and surgical techniques).

407 Id. at 8-9.

408 Best \& Dye, supra note 17 , at 5.
} 


\section{A. Nutrition and Digestive System Basics}

Nutrition is the master key to human health.

$$
\text { -T. Colin Campbell }{ }^{409}
$$

Nutrition is defined as "the process of providing or obtaining the food necessary for health and growth;" 410 "the sum of the processes by which an animal or plant takes in and utilizes food substances;" 411 or "the science that links food to health and disease." ${ }^{412}$ Food supplies energy for lawyers in the form of calories and the building block nutrients that create and maintain cells. ${ }^{413}$

A nutrient is essential if it supports at least one specific biological function, if elimination of the nutrient leads to a decline in biological function(s), and if restoration of the withheld nutrient, prior to any permanent damage, restores biological function(s). ${ }^{414}$ The essential nutrients are carbohydrates, proteins, lipids (also known as fats), water, vitamins, and minerals. ${ }^{415}$ Carbohydrates, proteins, and lipids are macronutrients because they are needed in large amounts (measured in grams), and vitamins and minerals are micronutrients because they are needed in small amounts (measured in milligrams or micrograms). ${ }^{416}$ People consume about one pound of protein, lipid, and carbohydrate; four teaspoons of minerals; and $1 / 15$ of a teaspoon of vitamins per day. ${ }^{417}$

The body's digestive system extracts nutrients from food and disposes of waste. ${ }^{418}$ The digestive tract runs from the lips to the anus and is about thirty feet long. ${ }^{419}$ Its major components are the mouth, esophagus, stomach, small intestine, and large intestine. ${ }^{420}$ Food is moistened and broken into smaller pieces in the mouth. ${ }^{421}$ After food

409 T. COlin CAMPBell, WhOlE: Rethinking THE SCIENCE OF NUTRITION xii (2014).

410 Nutrition, OXFORD ENGLISH DiCTIONARY (2d 1989).

411 Nutrition, WEBSTER's THIRD NEW INTERNATIONAL DiCTIONARY (3d ed. 1986).

412 SMITH \& COLLENE, supra note 5 , at 8.

413 See id.

414 Id.

415 DONNA SHRYER \& STEPHEN DAWSON, BODY FUEL: A GUIDE TO GOOD NUTRITION 7 (2010); Melvin H. Williams, Nutrition FOR HEALTh, Fitness \& SPORT 38 (8th ed. 2007); SMITH \& COLLENE, supra note 5, at 10.

416 SMITH \& COLLENE, supra note 5, at 11.

417 Id. at $13-14$.

418 KARA Rogers, THE Digestive System 117 (2011).

419 SHRYER \& DAWSON, supra note 415, at 5; ROGERS, supra note 418, at 19.

420 ROGERS, supra note 418, at 19.

421 Id. at 24. 
is swallowed, it travels about ten inches down a muscular tube, called the esophagus, to the stomach. ${ }^{422}$ In the stomach, food is mixed with gastric juices, made smaller and more soluble, and released periodically into the small intestine. ${ }^{423}$ The pancreas, gallbladder, and liver release fluids to aid with digestion. ${ }^{424}$ When food particles become small enough, they are transported into the bloodstream through the intestinal wall. ${ }^{425}$ When all the nutrients have been absorbed from the food, the remaining waste moves to the end of the large intestine and is excreted. ${ }^{426}$ Digestion processes food to enable nutrients to reach the bloodstream and be distributed to cells. ${ }^{427}$

The parasympathetic rest-and-digest system normally controls digestive function. ${ }^{428}$ Stress engages the sympathetic fight-or-flight system, slowing or stopping digestion and causing hiccups, heartburn, nausea, diarrhea, and constipation. ${ }^{429}$ Controlling stress promotes healthy digestion. ${ }^{430}$ Mindful eating is a technique that can reduce stress and aid digestion and includes eating in a relaxed manner and in calm, stress-free places; breathing slowly and deliberately during a meal; eating with others and expressing gratitude; limiting meals at your desk, computer, and tv; and taking the first step in digestion seriously, and thoroughly chewing your food. ${ }^{431}$

The human body relies on the synchronization of many highly structured organ systems composed of trillions of cells. ${ }^{432}$ Cells combine to form tissues and tissues combine to form organs. ${ }^{433} \mathrm{~A}$ person's overall nutritional status determines how well each organ functions. ${ }^{434}$ Cells undergo a consistent chemical process of production of new substances and breakdown of older substances, both of which

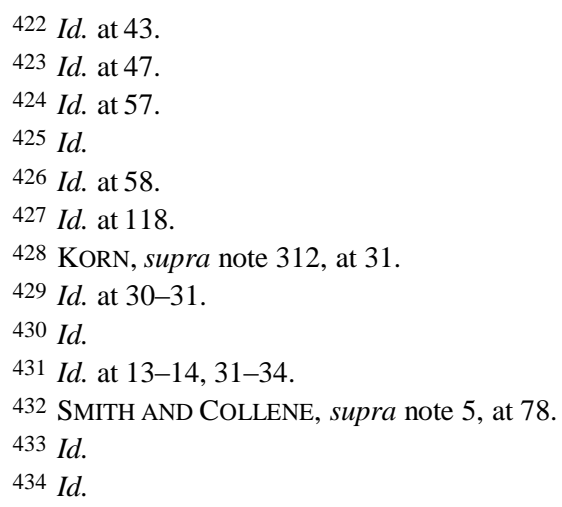


require energy from carbohydrate, protein, lipid, water, minerals, and vitamins. ${ }^{435}$ A healthy diet properly fuels the body's cells. ${ }^{436}$

Metabolism consists of all the chemical processes by which nutrients are utilized to support life. ${ }^{437}$ During these processes, the body releases and uses energy from food, synthesizes substances from others, and prepares waste for excretion. ${ }^{438}$ Metabolism has two functions: the building up of substances (anabolism) and the tearing down of substances (catabolism). ${ }^{439}$ Metabolism takes place in each cell when either a catabolic reaction releases energy by breaking down a nutrient into smaller component or an anabolic process, such as when proteins are built from amino acids. ${ }^{440}$ Other anabolic processes include the formation of hormones and enzymes, and the growth of bone and muscle tissue. ${ }^{441}$

Each cell has an inner and outer structure. ${ }^{442}$ The cell exterior is a cell membrane consisting of a double-layer of lipid, cholesterol, protein, and carbohydrate. ${ }^{443}$ Inside the cell, compartments and particles, called organelles, perform specialized functions. ${ }^{444}$ The liquid inside the cell is the cytoplasm, where a small amount of energy is produced by anaerobic metabolism, a chemical process that does not require oxygen. ${ }^{445}$ This process aids the survival of all cells and is the only source of energy production in red blood cells. ${ }^{446}$ Mitochondria, the cell's power plants, convert food energy to a form of energy cells can use via aerobic metabolism, which uses oxygen. ${ }^{447}$

Energy from the sun is captured by plants, which take carbon, hydrogen, oxygen, and nitrogen from their environment and produce carbohydrates, lipids, or proteins. ${ }^{448}$ The digestive system breaks down

$435 \mathrm{Id}$.

436 Id.

437 KAREN EICH DRUMMOND \& LISA M. BREFERE, NUTRITION FOR FOODSER VICE AND CULINARY PROFESSIONALS 18 (7th ed. 2010).

438 SMITH \& COLLENE, supra note 5, at 81 .

439 DRUMMOND \& BREFERE, supra note 437, at 18.

440 Id.

441 WILLIAMS, supra note 415 , at 91 .

442 SMith \& COLLENE, supra note 5, at 80.

443 Id. at 79-80.

444 See id. at 79-81 (stating that organelles include: cell nucleus, mitochondria, endoplasmic reticulum, Golgi complex, lysosomes, and peroxisomes).

$445 \mathrm{Id}$. at 80.

446 Id.

447 Id.

448 WILLIAMS, supra note 415 , at 86. 
these foods into simple compounds that are transformed by cells into energy for immediate or delayed use. ${ }^{449}$ The main fuel for the brain is glucose, which is supplied by carbohydrates. ${ }^{450}$ Other brain fuels include amino acids which form the neurotransmitters serotonin, norepinephrine, and epinephrine; calcium needed for the release of neurotransmitters; and Vitamin $\mathrm{B}_{12}$, which helps to form the insulating myelin sheath. ${ }^{451}$

The digestive system has been described as the second brain because it produces many of the neurotransmitters used by the body. ${ }^{452}$ The second brain digestive system also utilizes over thirty neurotransmitters. ${ }^{453}$ Food consumption is regulated largely by dopamine and serotonin, and ninety-five percent of the body's serotonin is found in the digestive system. ${ }^{454}$ The digestive tract contains bacteria that must remain in balance for optimal functioningthis environment is called the microbiome. ${ }^{455} \mathrm{~A}$ healthy level of beneficial bacteria supports stress regulation and maintains levels of GABA, the neurotransmitter that reduces anxiety. ${ }^{456}$ Beneficial gut bacteria promotes intestinal tract function, a healthy immune system, and weight control. ${ }^{457}$

Prebiotic foods such as onions, garlic, leeks, asparagus, bananas, beans, agave, chia, and chicory root create conditions where healthy bacteria can flourish in the digestive system. ${ }^{458}$ Probiotics are the beneficial bacteria required in a healthy digestive system that work to improve the immune system and prevent infection and inflammation. ${ }^{459}$ Probiotic bacteria produce GABA, serotonin, B Vitamins, folate, and Vitamin K. ${ }^{460}$ Probiotics can be consumed from supplements or from fermented foods like yogurt and cheese with live cultures, brewer's yeast, sauerkraut, kombucha, kimchi, miso, and

\footnotetext{
449 Id.

450 SMith \& COLLENE, supra note 5, at 89.

451 Id. at 88-89.

452 KORN, supra note 312, at 12, 29.

453 Id. at 32.

${ }^{454} \mathrm{Id}$.

455 Id. at 48.

456 Id.

457 BHATIA, supra note 8, at 176.

458 KORN, supra note 312 , at 51.

459 Id. at 52.

$460 \mathrm{Id}$.
} 
micro-algaes. ${ }^{461}$ Kefir, a yogurt-type tangy drink, is high in protein, calcium, and healthy bacteria. ${ }^{462}$

The body stores nutrients in various locations. Fat is stored in specialized cells in adipose tissue, and carbohydrate is stored shortterm in the form of glycogen in the liver and muscles. ${ }^{463}$ Glucose and amino acids are stored in the blood, and vitamins and minerals are stored in the liver. ${ }^{464}$ When nutrients from the diet are insufficient, the body breaks down its own tissues. ${ }^{465}$ When there is too much nutrient supplementation, some cannot be stored or excreted (Vitamin A and iron), and tissue damage occurs. ${ }^{466}$ The best approach to nutrient acquisition is from food. ${ }^{467}$

Nutrition is often taught using a reductionist approach by considering the ways in which each food adds specific nutrients to our diet. ${ }^{468}$ This view can lead lawyers to focus on counting daily calories and tracking the amount of carbohydrates, proteins, and lipids they consume. ${ }^{469}$ The author of The China Study and Whole: Rethinking the Science of Nutrition, T. Colin Campbell, argues that this approach oversimplifies how our bodies utilize food. ${ }^{470}$ When a lawyer eats, her body absorbs needed nutrients, but there is no direct relationship between the amount of a food that is consumed and the extent the body will utilize it. ${ }^{471}$ The nutrient levels in foods vary greatly, thus there is no way to know how much of a nutrient is bioavailable, or how much is used by the lawyer's body. ${ }^{472}$ Nutrient interaction is very complex because nutrients can modify the impact of other nutrients in the lawyer's body. ${ }^{473}$ The amount of a nutrient consumed in a meal and the amount of that nutrient that reaches the body's site of action depends on the body's needs at that given moment. ${ }^{474}$ The lawyer's body absorbs what

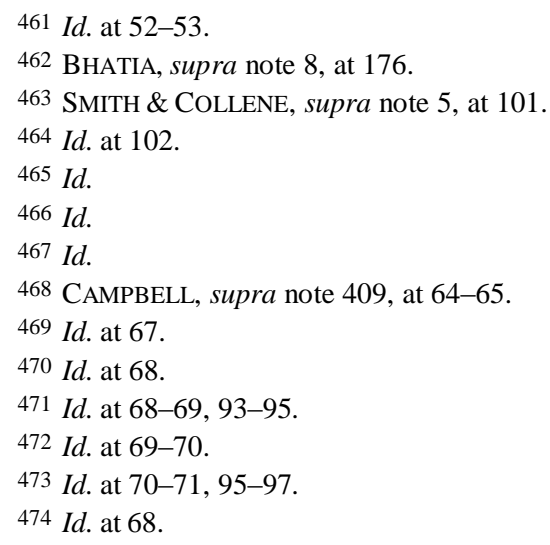


it needs and discards what it doesn't. ${ }^{475}$ Thus, Campbell contends lawyers should resist supplements, especially mega-dosing, in favor of ingesting whole foods that their bodies are designed to thrive on. ${ }^{476}$ Benefits from phytochemicals found in fruits and vegetables are also more pronounced from whole foods rather than in supplements. ${ }^{477}$

Body weight regulation requires a balance of energy intake from food and energy expenditure from daily activities and exercise. ${ }^{478} \mathrm{~A}$ high-energy diet coupled with a sedentary lifestyle can lead to obesity and diabetes. ${ }^{479}$ The body has a limitless capacity to store fat in adipose cells that can grow to six times their original size and can endlessly increase in number. ${ }^{480}$ Fat cells shrink in size during weight loss, but not in overall number. ${ }^{481}$ Obesity and diabetes increase the risk of depression, cognitive function, and dementia. ${ }^{482}$ If cell scientist Bruce H. Lipton's theory about cells moving to the protect-and-defend mode during stress and limiting nutrient absorption is accurate, eating to promote good health involves the lawyer's whole self. ${ }^{483}$

\section{B. The Western Diet}

The body typically relies on carbohydrates and fats for fuel and on protein to support body processes. ${ }^{484}$ Carbohydrates and protein contain about four calories per gram, while fat contains about nine calories per gram. ${ }^{485}$ All plant foods contain a mixture of carbohydrate, protein, and fat. ${ }^{486}$

Malnutrition encompasses any nutrition disorder. ${ }^{487}$ The Nutrition Paradox describes a condition where obesity coexists with malnutrition and vitamin deficiencies. ${ }^{488}$ High-calorie malnutrition occurs when an individual ingests an adequate number of calories but insufficient

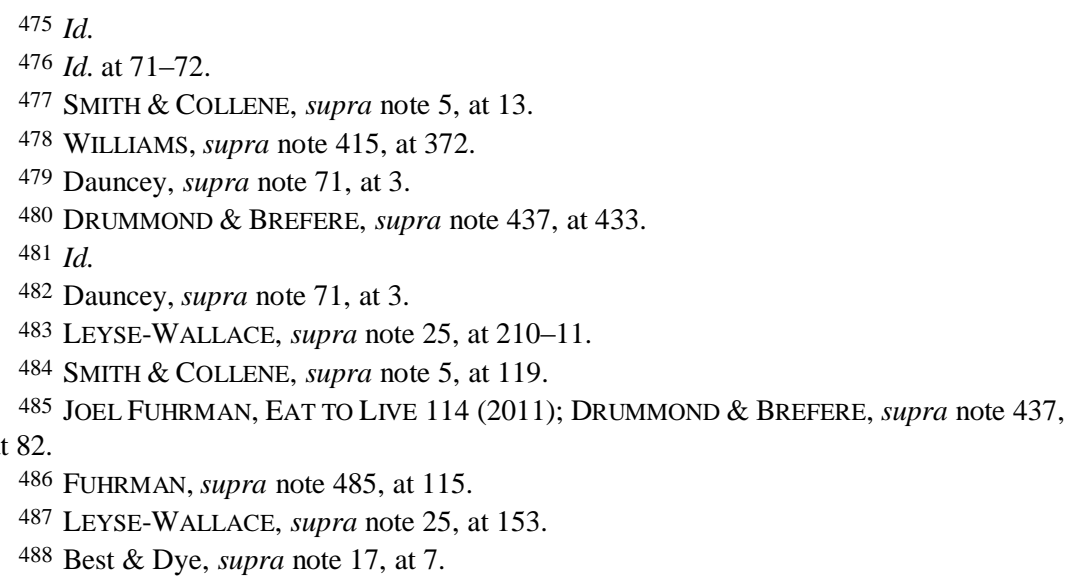


vitamins and minerals. ${ }^{489}$ This is often caused by a high intake of lownutrient calories such as sugar or alcohol or a high consumption of foods that are low in vitamins or minerals in proportion to the calories they contain. 490

The Western Diet is centered on animal fat, starch, and sugar. ${ }^{491}$ Americans on this diet consume about three-quarters of a pound of meat and poultry and an average of twenty-two teaspoons of added sugar per day. ${ }^{492}$ At the same time, they eat about half the fiber, fruits, and vegetables that they should. ${ }^{493}$ These dietary practices lead to excess insulin and inflammation known to cause cancer, heart disease, diabetes, and obesity. ${ }^{494}$ The high salt intake associated with the Western Diet increases risk of high blood pressure, cardiovascular problems, and kidney damage. ${ }^{495}$ High blood pressure, also known as hypertension, is an important brain risk factor in depression, brain aging, dementia, Alzheimer's disease, and stroke. ${ }^{496}$ High fat intake reduces the birth of new brain cells and BDNF levels in the hippocampus. ${ }^{497}$ Diets high in fat and sugar cause a decline in attention, memory, processing speed, verbal facility, and mental flexibility. ${ }^{498}$

Lawyers and law students do not need any meat or dairy products in their diets, the healthiest lawyers may be those who eliminate animal products, ${ }^{499}$ and a reduction in intake of animal products will improve, and may eliminate, general health and brain disorders. ${ }^{500}$ An understanding of how carbohydrates, proteins, and fats contribute to good health will help lawyers make better nutrition choices.

\footnotetext{
489 See id.

490 LEYSE-WALLACE, supra note 25, at 154.

491 BHATIA, supra note 8, at 18; Francis \& Stevenson, supra note 255, at 111.

492 BHATIA, supra note 8 , at 17-18.

493 Id. at 18.

494 Id.

495 Farooqui \& Farooqui, supra note 272, at 23.

496 Farooqui \& Farooqui, supra note 272, at 23-24.

497 Lopresti, supra note 317, at 97; Farooqui \& Farooqui, supra note 272, at 15, 18

498 Francis \& Stevenson, supra note 255, at 111-12.

499 BARNARD, supra note 218, at 58.

500 Id.
} 


\section{Carbohydrates}

Carbohydrate (often referred to as a carb) means hydrate of carbon, and carbs contain carbon, hydrogen, and oxygen atoms. ${ }^{501}$ During photosynthesis, plants use energy from sunlight, carbon dioxide from air, and water to create carbohydrates, which make up sixty to ninety percent of the plant's dry weight. ${ }^{502}$ Foods that supply carbohydrates are fruits, vegetables, legumes, dairy products, cereals, breads, and pasta. ${ }^{503}$ Legumes include beans, lentils, peas, and peanuts. ${ }^{504}$

Carbohydrates are the main fuel for red blood cells, nervous system cells, and brain cells. ${ }^{505}$ Carbs have gotten a bad reputation-one which should in fact be reserved for refined and simple carbohydrates, not for complex carbs obtained from vegetables, fruits, legumes, and whole grains. ${ }^{506}$ The latter are all nutrient-dense per calorie, and the bulk and fiber they contain leads to satiety without a calorie overload. ${ }^{507}$ In contrast, meat, dairy, and oils are so calorie dense, it is difficult for hunger to be satisfied without calorie overconsumption. ${ }^{508}$

The three main carbohydrates are simple carbohydrates, complex carbohydrates, and dietary fiber. ${ }^{509}$

\section{Simple Carbohydrates}

The simple carbohydrates are monosaccharides (single-sugar molecules) and disaccharides (double-sugar molecules). ${ }^{510}$ The simplest sugar monosaccharides are glucose, fructose, and galactose. ${ }^{511}$ Four common disaccharides are table sugar ("sucrose, [which is] a combination of glucose and fructose"), milk sugar ("lactose, [which is] a combination of glucose and galactose"), and corn syrup (which is "a combination of glucose and fructose"). ${ }^{512}$

\footnotetext{
501 DRUMMOND \& BREFERE, supra note 437, at 82.

502 Id.

503 SMITH \& COLLENE, supra note 5, at 119.

504 Id. at 209 (stating that legumes have pods containing a single row of seeds and beans are mature legume seeds).

505 Id. at 120; DRUMMOND \& BREFERE, supra note 437, at 82.

506 FUHRMAN, supra note 485, at 115.

507 Id.

508 Id. at 116.

509 SHRYER \& DAWSON, supra note 415 , at 9.

510 NANCY CLARK, NANCY CLARK'S SPORTS NUTRITION GUIDEBOOK 111-12 (Human Kinetics 5th ed. 2003).

511 Id. at 11.

$512 I d$.
} 
Other simple sugar food additives include honey, brown sugar, and maple syrup. ${ }^{513}$

The major monosaccharide found in the body is glucose, known as blood sugar in the bloodstream. ${ }^{514}$ Most glucose in the diet comes from table sugar and starch, which are "converted into glucose in the liver." ${ }^{15}$ Overconsumption of simple carbs harms both the brain and the body. ${ }^{516}$ In a study of 181 participants, age sixty-five and older with no history of dementia, those participants with elevated blood glucose had impairment of the dentate gyrus, a section of the hippocampus associated with age-related decline.${ }^{517}$ Research shows that ingestion of simple high-glycemic carbs impairs memory one to two hours later. ${ }^{518}$ High levels of simple carbs increase the risk of obesity and insulin resistance. ${ }^{519}$

\section{Complex Carbohydrates}

Complex carbohydrates "are formed when sugars link together to create long, complex chains." ${ }^{520}$ Vegetables tend to store excess sugar as starch (e.g. sweet corn becomes more starchy over time) and fruits tend to convert starches into sugars as they ripen (e.g., bananas). ${ }^{521}$ Starches in food like potatoes, bread, and rice are either burned for energy or stored as glycogen in the liver or muscles. ${ }^{522}$ Carbs in soft drinks or sports drinks supply energy but no vitamins or minerals (unless fortified). ${ }^{523}$ The carbs in fruits, vegetables, and whole grains

\footnotetext{
513 Id. at 113.

514 SMITH \& COLLENE, supra note 5, at 121.

$515 \mathrm{Id}$.

516 See BHATIA, supra note 8, at 17-20 (suggesting there is a correlation between overconsumption of carbohydrates and diseases like diabetes); LEYSE-WALLACE, supra note 25 , at 87 . Overconsumption of simple sugars can lead to diabetes, and people with diabetes experience cognitive impairment as well as other negative health impacts. A study comparing 168 diabetics with over 2000 control subjects found that the diabetics scored lower on tests of intellectual and verbal abilities. Id.

517 Judith Horstman, The SCIENTIFIC AMERICAN Healthy AgING BRAIN: The NeURoscience OF MAKING THE Most OF Your Mature Mind 152 (Jossey-Bass 1st ed. 2012).

518 See Farooqui \& Farooqui, supra note 272, at 19.

519 Id.

520 CLARK, supra note 510, at 113.

521 Id.

522 Id.

523 Id.
} 
provide energy along with vitamins, minerals, fiber, and phytochemicals. ${ }^{524}$

\section{Fiber}

Fiber is a group of non-starch polysaccharides that cannot be digested or absorbed, so it passes through the digestive system unchanged. ${ }^{525}$ Insoluble fiber, also known as nonfermentable fiber, neither dissolves in water, nor is metabolized by the bacteria in the intestines. ${ }^{526}$ Insoluble fiber gives plants their structure, provides a natural laxative that speeds up food travelling through the digestive system, and is found in wheat bran, whole grains, nuts, fruit skins, and some vegetables. ${ }^{527}$ Soluble fiber swells in water to form a gel and is readily fermented by the bacteria in the large intestine. ${ }^{528}$ Soluble fiber (found in beans, oats, oat bran, barley, lentils, chickpeas, and some fruits and vegetables) "reduces blood cholesterol and controls blood glucose." ${ }^{, 529}$ Fiber is lost during food processing, so a variety of whole fiber-rich foods should be consumed. ${ }^{530}$

\section{How Carbohydrates Work in the Body-Glucose and Glycogen Storage}

There are three major energy sources of carbohydrate in the body: blood glucose, liver glycogen, and muscle glycogen. ${ }^{531}$ Generally, digestible carbohydrates in the diet are converted into glucose to fuel red blood cells, the nervous system, and the brain. ${ }^{532}$ The supply of blood glucose is limited to about twenty calories, but blood glucose can be restored from glucose absorbed during digestion or from liver glycogen. ${ }^{533}$ The greatest concentration of glycogen is found in the liver, but one hour of aerobic exercise uses over half the liver glycogen supply, and "fifteen hours or more of starvation will deplete the liver

\footnotetext{
$524 I d$. at 114

525 DRUMMOND \& BREFERE, supra note 437, at 92; SMITH \& COLLENE, supra note 5, at

526 SMITH \& COLLENE, supra note 5, at 123.

527 ClARK, supra note 510, at 49; see DRUMMOND \& BREFERE, supra note 437, at 92; see also SMITH \& COLLENE, supra note 5, at 123.

528 CLARK, supra note 510, at 58; see DRUMMOND \& BREFERE, supra note 437, at 92; SMITH \& COLLENE, supra note 5, at 124.

529 SMITH \& COLLENE, supra note 5, at 124; see also CLARK, supra note 510, at 58.

530 CLARK, supra note 510, at 57.

531 WILLIAMS, supra note 415, at 120.

532 SMITH \& COLLENE, supra note 5, at 138 .

533 WILLIAMS, supra note 415 , at 120.
} 123. 
glycogen stores." ${ }^{534}$ A carbohydrate-rich diet can nearly double liver glycogen amounts. ${ }^{535}$

The largest amount of carbohydrate is stored in muscle glycogen because muscles make up such a large amount of body mass. ${ }^{536}$ The average lean, 150-pound male has approximately 1800 calories of carbs stored as glycogen, with 1400 in the muscles and 400 in the liver. ${ }^{537}$ Glycogen in the liver can supply glucose to the blood during normal activities, but muscle glycogen is reserved to fuel muscles during exercise. ${ }^{538}$ Between 60,000 and 100,000 calories are stored in the body as fat, but fat is not used to fuel high-intensity workouts because muscles require carbohydrates from glycogen to perform optimally. ${ }^{539}$ Moderate-intensity workouts burn fifty to sixty percent fat, while lowintensity activities are mostly fueled by fat calories. ${ }^{540}$ During intense exercise or endurance sports, muscles rely on the glycogen stores, but trained muscles have the capacity to store twenty to fifty percent more glycogen than untrained muscles. ${ }^{541}$

When muscle glycogen stores get too low, the endurance athlete experiences overwhelming fatigue. ${ }^{542}$ When liver glycogen is depleted, the athlete's brain suffers, and she can experience lightheadedness, weakness, and an inability to concentrate. ${ }^{543}$ While muscles have the capability both to store glucose and burn fat, the brain can do neither. ${ }^{544}$ The brain needs a steady supply of glucose to perform optimally, and healthy carbs can provide this critical energy source. ${ }^{545}$

Carbs are important to both aerobic exercise and strength training because they are stored in the muscles and provide fuel during

${ }^{534} I d$. (explaining how the liver can store 300-400 calories of glycogen).

535 See id.

536 Id.

537 DRUMMOND \& BREFERE, supra note 437, at 83; SMITH \& COLLENE, supra note 5, at 123.

538 SMITH \& COLLENE, supra note 5, at 123.

539 CLARK, supra note 510, at 120.

$540 \mathrm{Id}$.

541 Id.

542 See id. at 120.

543 Id. at 129.

544 Id.

545 Id. 
exercise ${ }^{546}$ Carbohydrate-rich proteins can be a good option for active lawyers - think beans and rice, lentil soup, hummus, and chili. ${ }^{547}$

If carb supply is inadequate, the body uses protein or fat for energy. ${ }^{548}$ Protein is usually utilized to build and maintain muscles and organs, but if carbs are insufficient, the body redirects amino acids to make glucose from proteins. ${ }^{549}$ Protein wasting from lengthy fasting eliminates protein from the muscles, heart, liver, and kidneys and can be life-threatening if body systems fail. ${ }^{550}$ When carb levels are deficient, the metabolism of fats is inefficient and incomplete, causing them to become ketone bodies. ${ }^{551}$ Ketones are released into the blood, where they are transported to body tissues for use as energy. ${ }^{552}$ The resulting ketosis disrupts normal acid-base balance. ${ }^{553}$

\section{The Glycemic Index}

The nutritional value of carbs used to be determined by whether the carb in question was simple or complex, but a more precise system assesses the capacity of the food to elevate blood sugar. ${ }^{554}$ The Glycemic Index (GI) evaluates carbs based on their impact on blood sugar, and high GI foods enter the blood stream quickly and increase the rate of glycogen replacement. ${ }^{555}$ Low to moderate GI foods enter the blood stream slowly and provide persistent energy. ${ }^{556}$ Before endurance sports or arduous intellectual activities, low GI foods will supply sustained energy. ${ }^{557}$ Physically fit people are able to store the glycogen from digested sugar in their muscles and require less insulin than sedentary people. ${ }^{558}$ Harvard Medical School provides a GI food

\footnotetext{
546 Id. at 120 .

547 Id. at $59,99$.

548 SMITH \& COLLENE, supra note 5, at 138.

549 Id.

$550 \mathrm{Id}$.

551 Id.

552 Id.

553 Id.

554 CLARK, supra note 510, at 115.

555 Id.

556 Id. at 117.

557 Id.

$558 I d$. at 118
} 
chart online that describes the glycemic load of many beverages, processed foods, dairy, grains, beans, nuts, fruits, and vegetables. ${ }^{559}$

Research shows that attention and memory are impaired, in both children and adults, following consumption of a high GI meal. ${ }^{560}$ In animal studies, long-term high GI diets compromise learning and memory processes. ${ }^{561}$

\section{Protein}

"Protein was discovered by Gerardus Mulder in $1839 " 562$ and is so important, its name comes from the Greek word meaning "first." 563 "Like carbohydrates and fats, proteins contain carbon, hydrogen, and oxygen," but they also have nitrogen. ${ }^{564}$ Proteins are long chains of amino acids, and eleven of the twenty can be manufactured by the body. ${ }^{565}$ Amino acids are the building blocks of protein, and humans require nine essential amino acids to come from their diet. ${ }^{566}$ Animal proteins are described as high-quality or complete proteins because they contain all nine essential amino acids, thus the human body can metabolize animal protein more efficiently than plant protein. ${ }^{567}$

Approximately seventy percent of the protein in the Western Diet comes from five sources: beef, poultry, milk, cheese, and white bread. $^{568}$ The consumption of animal proteins has been steadily dropping in the United States, but increasing in Asia, particularly in China and India. ${ }^{569}$ High consumption of animal proteins creates negative environmental impacts, in addition to undesirable health effects. ${ }^{570} \mathrm{~A}$ diet high in animal protein impairs kidney function, and

559 See Glycemic Index and Glycemic Load for 100+ Foods, HARVARD HEALTH PUBL'NS (Feb. 2015), http://www.health.harvard.edu/diseases-and-conditions/glycemic _index_and_glycemic_load_for_100_foods.

560 Francis \& Stevenson, supra note 255, at 112.

$561 \mathrm{Id}$.

562 CAMPBELL, supra note 409, at 31.

563 DRUMMOND \& BREFERE, supra note 437, at 162.

564 Id.

565 Id. See generally WiLliams, supra note 415, at 195.

566 SMITH \& COLLENE, supra note 5, at 202-03.

567 Id. at 207; CAMPBELL, supra note 409, at 31

568 SMITH \& COLLENE, supra note 5, at 206.

569 Id.

$570 \mathrm{Id}$. 
increases the risk for diabetes, depression, stroke, and Alzheimer's disease. ${ }^{571}$

Research shows that animal protein consumption has a greater impact on cancer growth than chemical carcinogens ${ }^{572}$ because animal protein ignites cancer growth within cells, and "protein, once consumed, works within the cell to turn on the cancer process." 573 The protein in cow's milk has been shown to stimulate cancer development in scientific experiments. ${ }^{574}$ Cancer growth can be reduced when animal protein consumption is cut. ${ }^{575}$ In a rodent study, all the rats in the group that were fed a powerful carcinogen, aflatoxin, and a diet of twenty percent casein protein from dairy developed liver cancer or cancer precursor legions. ${ }^{576}$ The rats in the other group that consumed the aflatoxin but were limited to five percent casein protein did not develop cancer. ${ }^{577}$ In this study, plant proteins did not encourage cancer growth. ${ }^{578}$

Plant proteins are a healthy alternative to animal proteins. ${ }^{579}$ Plant proteins contain very little saturated fat and cholesterol, making them beneficial to both the heart and brain. ${ }^{580}$ Soy protein and quinoa seed are complete plant proteins. ${ }^{581}$ To acquire all nine essential amino acids from plants, a lawyer must consume different combinations of plant proteins, such as beans and rice or vegetables and nuts. ${ }^{582}$

Eating protein helps a lawyer feel fuller and more satisfied than carbs or fat. ${ }^{583}$ Good plant proteins include seeds, nuts, and legumes. ${ }^{584}$ One ounce of seeds (such as pumpkin or sunflower seeds) or nuts (such as almonds, pecans, pistachios, or walnuts) provides 160 to 190 calories, six to ten grams of protein, and fourteen to nineteen grams of

571 Farooqui \& Farooqui, supra note 272, at 21.

572 CAMPBEll, supra note 409, at 33; MichaEL GREGER WITH GENE STONE, How NOT TO DIE 66-67, 69-70, 75 (2015).

573 CAMPBELL, supra note 409, at 32; GREGER, supra note 572, at 213-15.

574 CAMPBELL, supra note 409, at 36, 39, 92.

575 Id. at 36.

$576 I d$. at $30-31$.

577 Id.

578 Id. at 31.

579 SMITH \& COLLENE, supra note 5, at 209.

$580 \mathrm{Id}$.

581 Id. at 207.

582 Id. at 209.

583 Farooqui \& Farooqui, supra note 272, at 21.

584 SMITH \& COLLENE, supra note 5, at 209. 
fat. ${ }^{585}$ Nuts grow on trees; peanuts are legumes because they grow underground. ${ }^{586}$ Legumes have pods containing a single row of seeds, which include great northern beans, kidney beans, soybeans, lentils, garden peas, black-eyed peas, and peanuts. ${ }^{587}$ Beans are mature legume seeds, and one half cup supplies 100 to 150 calories, five to ten grams of protein, five grams of fiber, and less than one gram of fat. ${ }^{588}$ Soaking dry beans in water releases the indigestible carbs they contain and limits intestinal gas. ${ }^{589}$

Every cell contains protein and most proteins are in a constant cycle of breakdown, repair, and regeneration. ${ }^{590}$ North American adults consume about sixty-five to 100 grams of protein per day, but their body degrades and remakes about 250 grams daily in a protein turnover process that recycles most amino acids. ${ }^{591}$ Muscles, connective tissue, hormones, enzymes, and antibodies are made of protein. ${ }^{592}$ Surplus protein does not enhance body development, but a protein deficit can slow tissue repair and compromise the immune system. ${ }^{593}$ Adults need about fifteen percent of their calories from protein, with the upper limit at thirty-five percent of total calories. ${ }^{594}$ Plant proteins are low in calories, saturated fat, and cholesterol. ${ }^{595}$

\section{E. Fats}

Lipids are energy dense, and they provide nine calories per gram in comparison to the four calories per gram found in carbohydrates and proteins. ${ }^{596}$ Lipids include fats, oils, cholesterol, and lecithin. ${ }^{597}$ Fats and oils are found in both animals (usually solids) and plants (usually

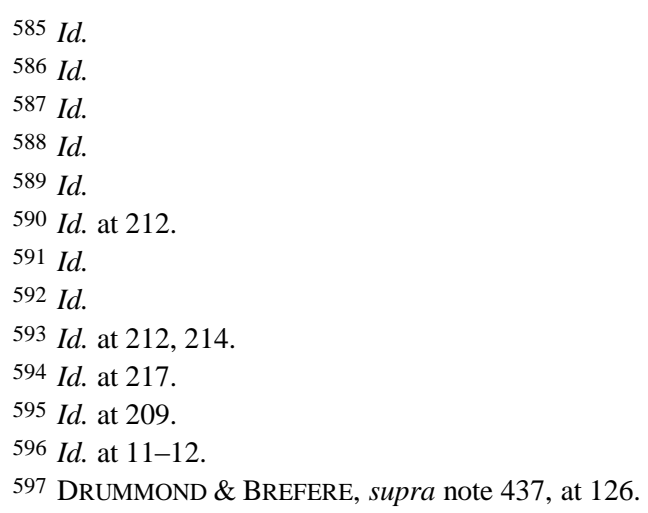


oils). ${ }^{598} \mathrm{~A}$ lipid is a fat if it is solid at room temperature and an oil if it is liquid at room temperature. ${ }^{599}$ Lipids do not dissolve in water. ${ }^{600}$

Like carbohydrates, lipids consist of carbon, hydrogen, and oxygen. ${ }^{601}$ Most of the lipids in foods and in the body are triglycerides, and the others are sterols, such as cholesterol, and phospholipids. ${ }^{602}$ Triglycerides are made up of fatty acids and glycerol. ${ }^{603}$ Fatty acids are chains of carbon, hydrogen, and oxygen atoms that vary in both length and carbon saturation. ${ }^{604}$

Food experts and chefs describe lipids as fats, and to simplify the discussion of lipids, this Article will use the general term-fat. ${ }^{605}$ Dedicated fat cells (also known as adipose cells) store large amounts of fat and can increase in weight approximately fifty times. ${ }^{606}$ Fat plays an important role in cell membranes and "transports the fat-soluble vitamins throughout the body." 607 Fat prevents protein from being burned as energy, conserving it for other functions. ${ }^{608}$ Although twenty to thirty-five percent of the adult diet can be fat, very little fat is needed to maintain optimal health: only two to four tablespoons of plant oil daily and fatty fish (salmon or tuna) twice per week. ${ }^{609}$

The major fat in the body and in foods, triglycerides, contains fatty acids. ${ }^{610} \mathrm{~A}$ fat is considered saturated, monounsaturated, or polyunsaturated based on the fatty acid that is present in the greatest concentration. ${ }^{611} \mathrm{~A}$ fatty acid is a long chain of carbons flanked by hydrogen on both sides. ${ }^{612}$

To picture a fatty acid, think of a centipede. Each body segment is a carbon and each body segment has a pair of legs, which are hydrogen molecules. ${ }^{613}$ A saturated fatty acid is a carbon centipede with every

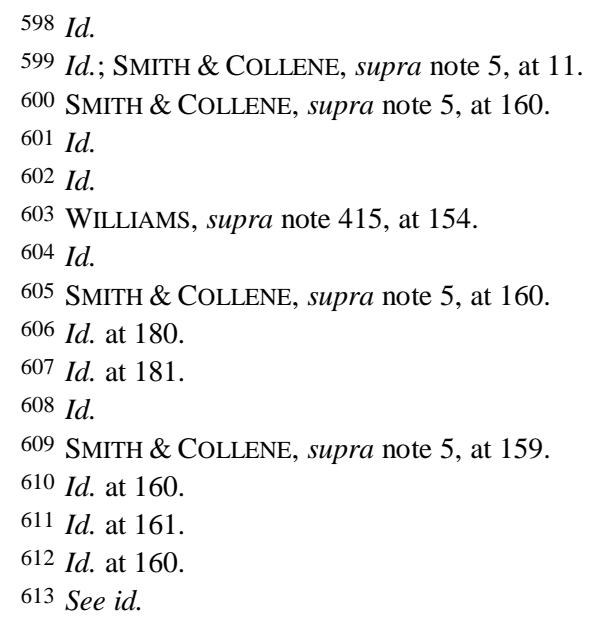


one of its hydrogen legs, making it fully saturated with hydrogens, solid at room temperature, and likely an animal fat like the white ring of "fat surrounding a piece of uncooked steak." ${ }^{\prime 614}$

A monounsaturated fat is a carbon centipede with two missing hydrogen legs on one side, missing two adjacent carbon body segments. ${ }^{615}$ The adjoining carbon body segments share a double carbon bond with each other and are less solid because they are less saturated with hydrogen. ${ }^{616}$ Foods rich in monounsaturated fat are avocados, canola oil, and olive oil. ${ }^{617}$

A polyunsaturated fat is a carbon centipede with two sets of doublebonded carbon body segments that are missing their hydrogen legs. ${ }^{618}$ Foods with a high percentage of polyunsaturated fats are corn, safflower, soybean, and sunflower oils. ${ }^{619}$ A trans fatty acid is created when an unsaturated fat is processed to artificially move hydrogen legs into the positions where they were missing from the carbon body segments. ${ }^{620}$

\section{Unhealthy Fats}

Saturated, trans, and polyunsaturated fats endanger the lawyer brain and heart. ${ }^{621} \mathrm{~A}$ high saturated fat intake increases the risk of impaire attention, memory, processing speed, mental flexibility, and verbal fluency. ${ }^{622}$ The Western Diet typically involves overconsumption of fat and sugar in processed foods, and this combination likely causes attention and memory decline due to oxidation, inflammation, and a reduction of BDNF. ${ }^{623}$ Studies show that the abilities to sustain attention, to learn, and to remember are harmed by high fat and sugarladen processed foods. ${ }^{624}$ The oxidation, inflammation, and decreased levels of BDNF caused by the Western Diet also increase the risk of

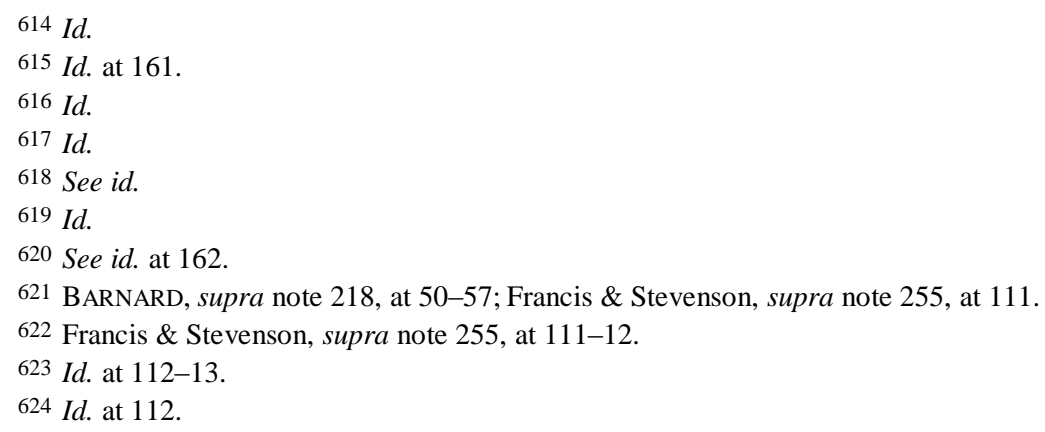


depression, mild cognitive impairment, Parkinson's disease, and Alzheimer's disease. ${ }^{625}$

Fat acts as an appetite stimulant - the more you consume, the more you crave. ${ }^{626}$ Processed foods are products designed to overstimulate the motivation and reward system in the brain with high fat and sugar content, and the brain impact of hyperpalatable foods parallels that of drugs of abuse. ${ }^{627}$ The desire to consume hyperpalatable foods is seated in the dopamine repeat-behavior system, and the enjoyment of those foods is controlled by the opioid and endocannabinoid hedonic hot spots. ${ }^{628}$ Research on animals suggest that processed foods rich in saturated fat and added sugar can cause food addiction when the dopamine system is downregulated, and withdrawal of such a diet mirrors rodent behaviors observed during the withdrawal of drugs of abuse. ${ }^{629}$

In saturated and trans fats, the fat molecule is covered or saturated with hydrogen atoms. ${ }^{630}$ Saturated fats are found in dairy products and the marbling in meat. ${ }^{631}$ A high-risk amount of daily saturated fat is about twenty-five grams, the amount found in the following daily menus: bacon and eggs, a grilled cheese sandwich, and meat; or cereal and milk, salmon salad, and half a cheese pizza. ${ }^{632}$

Trans fat, also known as partially hydrogenated oil, is created when food manufacturers turn liquid oils into solid fats in the hydrogenation process. ${ }^{633}$ Research shows that those who consume the most saturated and trans fats have the highest risk of developing Alzheimer's disease. ${ }^{634}$ High cholesterol is a predictor of Alzheimer's because saturated and trans fats cause a body to produce more cholesterol, which can result in blood-flow reducing plaques in the heart and brain. $^{635}$

Polyunsaturated fats present a health risk because the double carbon bonds are vulnerable to oxidation. ${ }^{636}$ Limiting polyunsaturated fat in

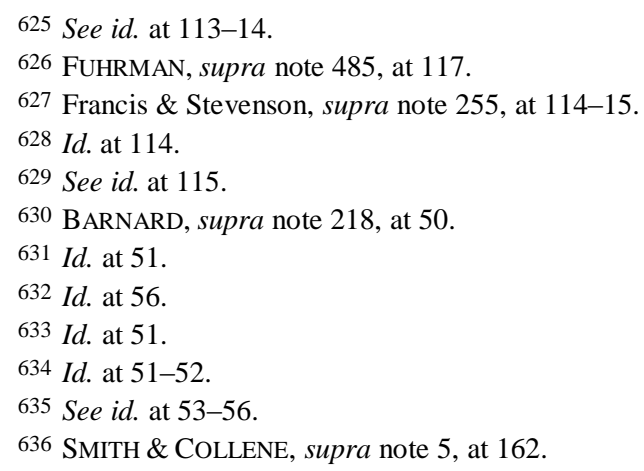


the lawyer diet reduces the risk of oxidation-induced inflammation, which can promote aging, cancer, neuron damage, and Alzheimer's. ${ }^{637}$ Oils to limit due to their polyunsaturated fat content are corn, safflower, soybean, and sunflower. ${ }^{638}$

Lawyers should read nutrition labels on processed foods to understand where they may be consuming harmful fats such as animal fats (bacon, beef, chicken, ham, lamb, lard, pork, and turkey); dairy fats (butter and cream); polyunsaturated oils; and partially hydrogenated shortening or oil. ${ }^{639}$

\section{Healthy Fats}

However, lawyers need some fat in their diets because their cell membranes are composed of two protein layers with a filling of fat in between. ${ }^{640}$ Research has shown that having a high amount of Omega3 fats in blood cells can protect against cognitive decay. ${ }^{641}$ Consistent intake of Omega-3 fatty acids protects both brain and cardiovascular health. ${ }^{642}$

To better understand Omega-3, Omega-6, and Omega-9 fatty acids, we return to the carbon chain unsaturated fat centipede. The head of the fatty acid centipede is the methyl group omega end, and the tail is the acid group end. ${ }^{643}$ The location of the first double-carbon bond, where two carbons are bonded and there are no hydrogen legs on one side, can be three, six, or nine carbons from the methyl omega head. ${ }^{644}$ If the first carbon bond is three carbons from the methyl omega head, it is an Omega-3 fatty acid. ${ }^{645}$ If the first carbon bond is six carbons from the methyl omega head, it is an Omega- 6 fatty acid, and if it is nine carbons away, it is an Omega-9 fatty acid. ${ }^{646}$ Omega- 3 and Omega- 6 fatty acids are essential to the lawyer diet, which are acquired only from foods

\footnotetext{
637 Id.; see also LEYSE-WALLACE, supra note 25, at 87.

638 See SMith \& COLLENE, supra note 5, at 161 (providing examples of some oils that are rich in polyunsaturated fatty acids).

639 See id. at 169 (providing examples of foods that contain hidden fats).

640 See BARNARD, supra note 218 , at 59.

641 Id.

642 SMITH \& COLLENE, supra note 5, at 164 (suggesting that regularly ingesting omega3 along with other types of acids can help ensure brain and cardiovascular health).

643 Id. at 161.

644 Id. at 162.

645 Id. In food, the major Omega-3 fatty acid is alpha-linolenic acid. Id.

$646 \mathrm{Id}$. at 162 . In food, the major Omega-6 fatty acid is linoleic acid and Omega-9 is oleic acid. $I d$.
} 
because the human body is incapable of producing them. ${ }^{647}$ Conversely, Omega-9 is synthesized in the body and does not need to be part of the diet. 648

Good fats in fruits, vegetables, and nuts can be transformed in the body to the type of fat that the lawyer brain requires. ${ }^{649}$ Walnuts, chia seeds, flax seeds, flax oil, and canola oil are rich sources of the Omega3 fat alpha-linolenic acid (ALA). ${ }^{650}$ The body uses enzymes to convert Omega-3 ALA into eicosapentaenoic acid (EPA) and docosahexaenoic acid (DHA), which are both critical to the optimization of the brain and nervous system. ${ }^{651}$ Fatty fish (salmon, tuna, halibut, anchovies, catfish, herring, mackerel, striped bass and trout) are good sources of preformed EPA and DHA. ${ }^{652}$ Omega-3 fatty acids reduce inflammation and decrease blood clotting, and they can lower blood triglycerides, and can improve depression. ${ }^{653}$

Omega-6 fatty acids, which primarily come from animal sources in the diet, increase inflammation and create a risk of cardiovascular problems. ${ }^{654}$ Omega- 6 fats are found in the following cooking oils: corn, cottonseed, grapeseed, safflower, soybean, and sunflower. ${ }^{655}$ Most lawyers should greatly limit the intake of oils to maintain a healthy ratio of Omega- 6 and Omega-3 fats: two to four grams of Omega- 6 for every gram of Omega-3. ${ }^{656}$ The Paleo Diet, as practiced during the Stone Age, had an Omega-6 to Omega-3 ratio of 1:1. ${ }^{657}$ Meat-eating lawyers who want to lower the risk of inflammation and increase the brain building blocks EPA and DHA should decrease Omega- 6 fatty acids, increase Omega- 3 fatty acids, and strive for a ratio closer to $1: 1{ }^{658}$ For lawyers considering supplements, a healthy, vegan option for DHA is from an algae source, rather than from fish. ${ }^{659}$

\footnotetext{
647 See id. at 163 . Only plants can make the parent fatty acids for Omega-3 and Omega6. $I d$. 


\section{F. Vitamins and Minerals}

The macronutrients required by humans in substantial daily amounts for making energy and building body tissue include carbohydrates, proteins, fats, and water. ${ }^{660}$ Micronutrients are small amounts of vitamins and minerals needed to regulate metabolic processes. ${ }^{661}$ The vitamins that provide protection for the brain include Vitamin E, Vitamin $\mathrm{B}_{6}$, Vitamin $\mathrm{B}_{12}$, and folate. ${ }^{662}$

\section{Vitamin E}

Vitamin $\mathrm{E}$ is an antioxidant that neutralizes free radicals. ${ }^{663}$ Vitamin $\mathrm{E}$ is fat-soluble and is present in adipose cells and the lipid bilayers of cell membranes. ${ }^{664}$ Because the lipids in these cell membranes are mostly polyunsaturated fatty acids and are vulnerable to oxidation, Vitamin E can provide electrons or hydrogen to free radicals and stabilize them. ${ }^{665}$ Vitamin E appears to afford the most protection to red blood cells and lung cells, both of which are exposed to high oxygen levels. ${ }^{666}$ Vitamin $\mathrm{E}$ may also prevent or reduce the creation of oxidized LDL cholesterol, potentially decreasing the risk of plaque formation in the arteries that leads to cardiovascular disease. ${ }^{667}$

Research shows that for every five milligrams of Vitamin $\mathrm{E}$ consumed daily, the risk of developing Alzheimer's disease is reduced by twenty-six percent. ${ }^{668}$ Two forms of Vitamin $E$ that work in tandem are alpha-tocopherol and gamma-tocopherol. ${ }^{669}$ Most supplements are limited to alpha-tocopherol; so to get both forms, one should consume eight to eighteen milligrams of Vitamin E-rich foods per day. ${ }^{670}$ Megadosing with Vitamin E supplements creates a risk of bleeding, and lawyers should obtain Vitamin E in foods. ${ }^{671}$ The best sources of

\footnotetext{
660 WILLIAMS, supra note 415 , at 39.

661 Id.

662 BARNARD, supra note 218, at 67.

$663 \mathrm{Id}$. at $67-68$.

664 SMITH \& COLLENE, supra note 5, at 291.

665 Id.

$666 I d$.

667 Id.

668 BARNARD, supra note 218, at 68 .

669 Id. at 69.

$670 \mathrm{Id}$.

671 SMITH \& COLLENE, supra note 5, at 293.
} 
Vitamin E are nuts, seeds, plant oils, and fortified breakfast cereals. ${ }^{672}$ A list of other foods containing Vitamin E can be found in the Vitamin Chart in Table 2.

\section{The B Team}

As the cells in the lawyer's body build protein, they create a toxic byproduct called homocysteine. ${ }^{673}$ High levels of homocysteine in the blood increase the risk of heart attack, stroke, and cognitive decline. ${ }^{674}$ B Vitamins ( $\mathrm{B}_{6}, \mathrm{~B}_{12}$, and folate), working in tandem, clear homocysteine from the blood and improve memory problems in older participants. ${ }^{675}$ Lawyers with high homocysteine levels can suffer from mild cognitive impairment to Alzheimer's disease, so sufficient intake of B Vitamins is necessary to reduce this risk. ${ }^{676}$ Increased B Vitamins have increased the size and improved the function of the memoryprocessing hippocampus. ${ }^{677}$

Research indicates that people who suffer from depression have low levels of folate (also known as folic acid) and Vitamin $\mathrm{B}_{12}$ and high levels of homocysteine. ${ }^{678}$ Vegetarians and the elderly are particularly at risk for low Vitamin $\mathrm{B}_{12}{ }^{679}$ Vitamin $\mathrm{B}_{12}$ is best obtained from a supplement or fortified foods such as breakfast cereals or plant milks. ${ }^{680}$ It is poorly absorbed from animal products and not present in plants. ${ }^{681}$ A list of food containing B Vitamins is provided in the Vitamin Chart in Table 2.

672 Id. at 292

673 See BARNARD, supra note 218 , at 71 .

674 Id. at $71-72$.

$675 \mathrm{Id}$. at $71-73$.

676 BARNARD, supra note 218, at 73; LEYSE-WALLACE, supra note 25, at 84; Celeste A. De Jager \& Samrah Ahmed, Research on the Effects of Vitamins and Minerals on Cognitive Function in Older Adults, in NUTRITION FOR BRAIN HEALTH AND COGNITIVE PERFORMANCE 206-07 (2015).

677 See Best \& Dye, supra note 17, at 4.

678 LEYSE-WALLACE, supra note 25, at 101, 107, 116.

679 See id. at 200.

680 See BARNARD, supra note 218, at 75; Jager \& Ahmed, supra note 676, at 206-07.

681 Id. at 75-76; Jager \& Ahmed, supra note 676, at 206. 
Table 2. Vitamin Chart

\begin{tabular}{|c|c|c|}
\hline & $\begin{array}{c}\text { Recommended Dietary } \\
\text { Allowance }\end{array}$ & Food Sources \\
\hline Vitamin E & $\begin{array}{l}22.4 \text { IU per day } \\
15 \text { mg per day }\end{array}$ & $\begin{array}{l}\text { Trace amounts of Vitamin E } \\
\text { are in apples, asparagus, } \\
\text { avocados, blackberries, } \\
\text { broccoli, collard greens, egg } \\
\text { yolk, melons, mangoes, } \\
\text { spinach, sweet potatoes, and } \\
\text { whole grains, but much larger } \\
\text { amounts are found in the } \\
\text { following nuts and seeds: } \\
\text { almonds, hazelnuts, pecans, } \\
\text { pine nuts, pistachios, walnuts, } \\
\text { flaxseed, sesame seeds, and } \\
\text { sunflower seeds. The best } \\
\text { sources are almonds and } \\
\text { sunflower seeds. }\end{array}$ \\
\hline Folate & 400 micrograms per day ${ }^{685}$ & $\begin{array}{l}\text { Asparagus, broccoli, green } \\
\text { leafy vegetables, and } \\
\text { spinach. } 686\end{array}$ \\
\hline Vitamin $\mathrm{B}_{6}$ & $\begin{array}{l}1.3 \mathrm{mg} \text { per day for adults to } \\
\text { age } 50 \\
1.5 \mathrm{mg} \text { per day for women } \\
\text { over } 50 \\
1.7 \mathrm{mg} \text { per day for men over } \\
50^{687}\end{array}$ & $\begin{array}{l}\text { Bananas, beans, green } \\
\text { vegetables, nuts, sweet } \\
\text { potatoes, and whole grains. }\end{array}$ \\
\hline Vitamin $\mathrm{B}_{12}$ & 2.4 micrograms per day ${ }^{689}$ & $\begin{array}{l}\mathrm{B}_{12} \text { is one of the rare } \\
\text { micronutrients that is best } \\
\text { ingested from a supplement, } \\
\text { from fortified breakfast cereals, } \\
\text { or from fortified soy milk. }{ }^{690} \text { It } \\
\text { is poorly absorbed from animal } \\
\text { products and is not found in } \\
\text { plants. }{ }^{691}\end{array}$ \\
\hline
\end{tabular}

682 BARNARD, supra note 218 , at 69.

683 SMITH \& COLLENE, supra note 5, at 292.

684 BARNARD, supra note 218, at 69-70; LEYSE-WALLACE, supra note 25, at 90; SMITH \& COLLENE, supra note 5, at 292.

685 BARNARD, supra note 218, at 74.

686 Id.

687 Id. at 75.

688 Id. at 74 .

689 Id. at 75.

690 Id.

691 Id. at 75-76. 


\section{G. Phytochemicals and Antioxidants}

Phytochemicals are compounds found in fruits and vegetables that may reduce the risk of cancer and cardiovascular disease. ${ }^{62}$ Although there is no legal definition of the term superfood, foods high in phytochemicals are often described as superfoods. ${ }^{693}$ Research indicates that whole foods provide the greatest health benefits from phytochemicals. ${ }^{694}$ Phytochemicals in fruit, vegetables, and tea are rich in Vitamins $\mathrm{C}$ and $\mathrm{E}$ and reduce cancer risk as well as protect against oxidative damage. ${ }^{695}$

An antioxidant is a compound that may stop the damage associated with oxidation and that helps to prevent the oxidation of substances in the body or in food-particularly lipids. ${ }^{696}$ Plants contain large numbers of antioxidants and have a synergistic effect, so eating a variety of different kinds of plants provides the most benefit. ${ }^{697}$ Plantbased foods that are rich in antioxidants include legumes, nuts, apples, berries, broccoli, cherries, grapes, onions, oranges, plums, prunes (dried plums), raisins, red bell peppers, and spinach. ${ }^{698}$ The number one source of antioxidants in the American diet is coffee. ${ }^{699}$ Tea also contains antioxidants. ${ }^{700}$

Polyphenols are phytochemicals that have antioxidant properties and are believed to protect plants from UV rays, disease, and drought. ${ }^{701}$ Polyphenols and flavonoids from plants have both anti-obesity and anti-diabetic effects. ${ }^{702}$ Flavonoids may encourage brain cell growth in the hippocampus and protect brain cells from damage, decreasing the risk of Alzheimer's and Parkinson's diseases. ${ }^{703}$ There are four classes of polyphenols:

692 SMITH \& COLLENE, supra note 5, at 13; DRUMMOND \& BREFERE, supra note 437 , at $222-23$.

693 SMITH \& COLLENE, supra note 5, at 13.

694 Id. at 13.

695 Id. at 329

696 Id. at 190

697 BHATIA, supra note 8, at 19.

698 SMITH \& COLLENE, supra note 5, at 191.

699 BHATIA, supra note 8, at 38.

700 SMITH \& COLLENE, supra note 5, at 191.

701 Lephart, supra note 231, at 143.

702 Farooqui \& Farooqui, supra note 272, at 22.

703 HORSTMAN, DAY IN THE LIFE, supra note 36, at 161. 
- Stilbenes, such as the resveratrol found in red wine; ${ }^{704}$

- Flavonoids (antioxidant and anti-inflammatory), contained in fruit, vegetables, legumes, red wine, tea, and chocolate. ${ }^{705}$ Dark chocolate containing at least seventy-percent cacao has some of the highest concentrations of antioxidant flavonoids of all food. ${ }^{706}$ Dark chocolate reduces stress hormone levels and may be metabolized in a way that does not lead to weight gain. ${ }^{707}$

- Lignans in legumes, flax, fruits, and vegetables $;^{708}$

- Phenolic Acids, found in tea, coffee, cinnamon, apples, blueberries, cherries, kiwis, and plums. ${ }^{709}$

Exercise increases the production of free radicals, which can be beneficial and assist with muscle contraction and the adjustments to increased fitness. ${ }^{710}$ Athletes and serial exercisers should consume diets rich in antioxidants from fruit, vegetables, and whole grains to protect against oxidative damage. ${ }^{711}$

\section{IV}

\section{CAFFEINE AND ALCOHOL}

\section{A. Caffeine}

Caffeine is a stimulant found in coffee beans, tea leaves, chocolate, soda, and energy drinks. ${ }^{712}$ When a lawyer starts the day with coffee or tea, caffeine blocks adenosine receptors in the brain. ${ }^{713}$ Adenosine is a neurotransmitter that induces sleep, and caffeine is its antagonist drug that connects with the adenosine receptor, obstructs it, and prevents it from promoting sleep. ${ }^{714}$ Caffeine also stimulates dopamine

704 Lephart, supra note 231, at 146.

705 See id. at 143; JOSEPH MERCOLA, Polyphenols - What They Are and Why You Need Them, MERCOLA.COM (Dec. 14, 2015), http://articles.mercola.com/sites/articles/archive /2015/12/14/polyphenols-benefits.aspx.

706 See BHATIA, supra note 8, at 39.

707 Id. at 39-40.

708 MeRCOLA, supra note 705.

709 Id.

710 SMITH \& COLLENE, supra note 5, at 420.

711 Id. at 421 .

712 MEYER \& QUENZER, supra note 165, at 393-94.

713 Id. at 395.

714 GIBB, supra note 38, at 180; MCKIM \& HANCOCK, supra note 191, at 216; MEYER \& QUENZER, supra note 165, at 397, 399. 
release in the brain. ${ }^{715}$ Three substances have been identified in chocolate that are similar to the endogenous cannabinoids in the brain, which may explain the pleasure lawyers experience from coffee, tea, and chocolate beyond the stimulating impact of caffeine. ${ }^{716}$

Caffeine is the most widely used psychoactive drug, exceeding nicotine, alcohol, and illicit drugs. ${ }^{717}$ Moderate, regular coffee intake is not a health hazard and may even provide cardiovascular health benefits. ${ }^{718}$ Caffeine reduces fatigue, improves concentration, and prolongs intellectual efficiency. ${ }^{719}$ Although the energy drink Red Bull contains sugar, taurine, and glucuronolactone, the stimulant effects are due largely to the caffeine. ${ }^{720}$

However, lawyer overconsumption of caffeine, in popular energy drinks such as Red Bull and Monster, can cause agitation, insomnia, tremors, seizures, gastrointestinal problems, heart palpitations, respiratory issues, and cardiac arrest. ${ }^{721}$ In one study, a forty-sevenyear-old male who increased his coffee intake from about ten cups per day to approximately thirty-six cups experienced depression, explosive anger, and paranoia, all of which were resolved with a reduction of coffee consumption. ${ }^{722}$

\section{B. Alcohol}

Alcohol is the second most widely used drug, trailing only caffeine, but it is the most abused drug. ${ }^{723}$ Alcohol is a mixed action drug because it starts in low doses as a stimulant, producing mild euphoria and reducing anxiety, but later depresses neural activity and in higher doses causes incoordination and sedation. ${ }^{724}$ The effects of alcohol on the brain are complex because alcohol acts on multiple neurotransmitters: GABA, glutamate, dopamine, and endorphins. ${ }^{725}$

\footnotetext{
715 GIBB, supra note 38, at 180; MCKIM \& HANCOCK, supra note 191, at 216.

716 MCKIM \& HANCOCK, supra note 191, at 217.

717 LEYSE-WALLACE, supra note 25, at 25.

$718 I d$. at 23.

719 Id.

720 Id. at 24.

721 GIBB, supra note 38, at 179-80; MEYER \& QUENZER, supra note 165, at 398.

722 LEYSE-WALLACE, supra note 25, at 23-24.

723 MEYER \& QUENZER, supra note 165, at 266.

724 NeIl R. CARlson, Physiology OF BeHAVIOR 631 (11th ed. 2013); NEIL V. WATSON $\&$ S. MARC BREEDLOVE, THE MIND's MACHINE: FOUNDATIONS OF BRAIN AND BEHAVIOR 95 (2012).

725 MEYER \& QUENZER, supra note 165, at 283-90.
} 
The sedating and calming effects of alcohol are due to increased GABA, which results in some degree of reduced anxiety, social disinhibition, and poor motor control. ${ }^{726}$ Alcohol also inhibits glutamate by reducing its effectiveness, even for social drinkers with low blood alcohol levels. ${ }^{727}$ Glutamate interference causes alcohol to impair learning and memory, disrupt long-term potentiation, and prevent neurogenesis (the birth of new neurons in the hippocampus). ${ }^{728}$ Like other addictive substances, alcohol releases dopamine, which promotes repeat behavior, and endorphins, the body's endogenous opioids. $^{729}$

Grapes and red wine are excellent sources of the antioxidant resveratrol, which prevents blood clots, damage to blood vessels, and reduces bad cholesterol. ${ }^{730}$ Modest alcohol intake has been shown to cut the risk of Alzheimer's disease by about fifty percent, but even limited alcohol use comes with an increased risk of liver disease, breast cancer in women, iron overload, and interference with folate absorption, which may increase homocysteine levels and impair folate's cancer protecting power. ${ }^{731}$

Research shows that heavy alcohol use shrinks brain volume frontal lobes (causing apathy, disinhibition, and impaired executive function), the hippocampus (causing memory problems), and the cerebellum (causing incoordination). ${ }^{732}$ Those who abstain from alcohol have greater brain volume than moderate and former drinkers. ${ }^{733}$ A lawyer does not have to drink heavily for years to cause damage to the brain and weakened cognition. ${ }^{734}$ A study of eighteen- to twenty-four-yearold college students who periodically participated in binge drinking showed verbal memory deficits, indicating damage to the hippocampus. ${ }^{735}$

Some college students are engaged in drunkorexiea behaviors, or disordered eating prior to drinking, to limit calories prior to alcohol use

726 CARLSON, supra note 724, at 633; WATSON \& BREEDLOVE, supra note 724, at 95.

727 See MEYER \& QUENZER, supra note 165, at 285.

728 See CARLSON, supra note 724, at 632; MEYER \& QUENZER, supra note 165, at 285.

729 CARLSON, supra note 724, at 632-33; MEYER \& QUENZER, supra note 165, at 287, 289.

730 BHATIA, supra note 8 , at 168 .

731 BARNARD, supra note 218, at 78-79.

732 MEYER \& QUENZER, supra note 165, at 277.

733 CARTER ET AL., THE HUMAN BRAIN, supra note 42, at 44.

734 MCKIM \& HANCOCK, supra note 191, at 154.

$735 \mathrm{Id}$. 
or to increase the high they experience. ${ }^{736}$ The practice involves skipping meals, inducing vomiting, consuming laxatives, or exercising heavily before intense drinking. ${ }^{77}$ In a study of 1184 students, over eighty percent of those who experienced an incident of heavy drinking in the prior thirty days reported practicing a drunkorexic behavior in the previous three months. ${ }^{738}$ Both men and women practice drunkorexic behaviors, but earlier research indicated that men are motivated to do so to save money to spend on alcohol, while women are trying to save calories from food prior to consuming calories from alcohol. ${ }^{739}$ Students who lived in fraternities and sororities were most likely to practice drunkorexic behaviors, followed by students who lived in residence halls on campus. ${ }^{740}$

Lawyers and law students with NQ may want to consider their relationship with alcohol and whether the brain impacts are worth the risks of alcohol consumption.

\section{$\mathrm{V}$ \\ OPTIMIZING THE LAWYER BRAIN}

Facts are easy to come by.

Finding a new way to think and a new confidence in our choices is difficult indeed.

$$
\text { -Seth Godin }{ }^{741}
$$

Healthy aging is defined as "the process of optimizing opportunities for physical, social and mental health to enable older people to take an active part in society without discrimination and to enjoy an independent and good quality of life ...."742 Major objectives are the preservation of brain reserve (the capacity to withstand physical damage) and cognitive reserve (active safeguarding of cognitive capacity). ${ }^{743}$ Successful aging involves limiting disability and disease,

736 John Johnson, College 'Drukorexia' More Common Than Thought, USA TODAY (July 3, 2016, 11:01 AM), http://www.usatoday.com/story/news/nation/2016/07/03/college -drunkorexia-more-common-than-thought/86653224/.

737 Id.

738 Jake New, 'Drunkorexia,' INSIDE HIGHER ED (June 30, 2016), https://www.inside highered.com/news/2016/06/30/study-8-10-students-said-they-engaged-behaviors-related -drunkorexia.

739 Id.

$740 \mathrm{Id}$.

741 Seth Godin, Taking Notes vs. Taking Belief, SETH Godin BLOG (June 23, 2016), http://sethgodin.typepad.com/seths_blog/2016/06/taking-notes-vs-taking-belief.html.

742 Andreeva \& Kesse-Guyot, supra note 12, at 30.

743 Id. 
maximizing the ability to recover from illness or injury, and protecting cognitive competence. ${ }^{744}$ Research-based interventions for optimizing successful aging include stress management, social connectedness, intellectual stimulation, physical activity, and healthy nutrition. ${ }^{745}$ Among the lifestyle recommendations for improving cognitive function, anxiety, depression, and substance use, nutrition and exercise are the most important. ${ }^{746}$

\section{A. Brain Health and Popular Diets}

Real food is medicine and fake food is toxic to brain health.

-Leslie Korn ${ }^{747}$

Doctors and scientists disagree on the most effective nutrition plan to optimize brain and general health. Because people eat a variety of foods, causing nutrients to interact, it is easier to conduct research on and to critique holistic diets. ${ }^{748}$ Although more research is needed to further illuminate the cause-effect relationship of food with health, current research indicates that diets rich in fruits, vegetables, fish, nuts, and legumes, combined with low or no consumption of meat and highfat dairy, reduce the risk of cognitive decline. ${ }^{749}$ It may help lawyers to consider the strengths and weaknesses of the following prominent diets: Paleo, Mediterranean, and Whole-Food Plant-Based; heed the recommendations for preventing depression and Alzheimer's; and consult with their doctors about making nutrition changes.

\section{Paleo Diet}

The Paleolithic Diet, known also as the stone-age diet, contains thirty-nine percent protein, forty percent carbohydrates, and twentyone percent fats-all derived from fresh fruits and green vegetables, seeds, lean meat, and seafood. ${ }^{750}$ The ratio between Omega- 6 and

744 Id.

745 Id.

746 See KORN, supra note 312, at xi; Lephart, supra note 231, at 145-46.

747 KORN, supra note 312, at 24.

748 Marialaura Bonaccio, Giovanni de Gaetano \& Licia Iacoviello, Effect of a Mediterranean Diet on Mental and Physical Quality of Life, in DIET AND EXERCISE IN Cognitive Function And Neurological Diseases 42 (Farooqui \& Farooqui eds., 2015).

749 Andreeva \& Kesse-Guyot, supra note 12, at 23.

750 Farooqui \& Farooqui, supra note 272, at 15. 
Omega-3 fatty acids is $1: 1{ }^{751}$ This diet is also known as the Traditional or Authentic Diet and features foods that are low glycemic and high in antioxidants, fiber, and Omega-3 fatty acids. ${ }^{752}$ Fat sources include fish, birds, wild game, and plants. ${ }^{753}$ Digestion and gut health are optimized with prebiotics (bran, cactus, chia, oatmeal, and psyllium) and probiotics (kefir, kimchi, sauerkraut, and yogurt). ${ }^{754}$ Processed food from cans and packages, refined sugar and grains, synthetic preservatives, and food coloring are eliminated. ${ }^{755}$ Research indicates that high-protein diets promote free radical production. ${ }^{756}$ If lawyers who eat meat can maintain a healthy Omega- 6 and Omega- 3 fatty acid ratio and can consume adequate vegetables and fruit, the Paleo Diet may minimize inflammation and oxidative stress. ${ }^{757}$

\section{Mediterranean Diet}

The Mediterranean Diet was named by Ancel Keys in the 1960s after research showed that populations overlooking the Mediterranean Sea had significantly lower rates of cardiovascular disease and cancer than other populations. ${ }^{758}$ People who consume the Mediterranean Diet live longer and healthier lives; enjoy better health status; have better blood pressure, lipid metabolism, and cardiovascular health; and have a reduced risk of inflammation, cancer, obesity, depression, age-related cognitive decline, and Alzheimer's disease. ${ }^{759}$ The Mediterranean Diet contains "lots of fruit, green vegetables, grains, cheese, olive oil, beans, red wine, and yogurt, with some fish, poultry, and eggs." ${ }^{760}$ Research at the Harvard School of Public Health showed that the Mediterranean Diet could prevent ninety percent of type 2 diabetes, eighty percent of heart disease, and seventy percent of stroke cases. ${ }^{761}$ 
Foods in the Mediterranean Diet that are linked to a reduced risk of cognitive deterioration and dementia are fruits and vegetables (antioxidants, polyphenols); olive oil (unsaturated fatty acids, Vitamin E, polyphenols); and fish (fatty acids, Vitamin $\mathrm{B}_{12}$ ). ${ }^{762}$ The health benefits from foods rich in antioxidants, polyphenols, fiber, and monounsaturated fats are due to their anti-inflammatory and antioxidation properties. ${ }^{763}$

A 2013 meta-analysis found that high adherence to the Mediterranean Diet was "consistently associated with a forty percent reduced risk of cognitive impairment (including mild cognitive impairment, dementia, and Alzheimer's), a twenty-nine percent reduced risk of stroke and a thirty-two percent reduced risk of depression."764 Moderate commitment to the Mediterranean Diet was associated with reduced risk of cognitive deterioration and depression. $^{765}$

The nine dietary characteristics of the Mediterranean Diet are: (1) high ratio of monounsaturated to saturated fatty acids (mainly olive oil); (2) high consumption of fruit; (3) high consumption of vegetables; (4) high consumption of legumes and nuts; (5) high consumption of non-refined cereals, including bread; (6) moderate consumption of milk and dairy products; (7) moderate ethanol consumption (mainly red wine); (8) low consumption of red meat, meat products, and poultry; and (9) high consumption of fish. ${ }^{766}$ A good quality of life is associated with high cognitive function, low levels of depression, strong physical health, and robust social connections. ${ }^{767}$ Lawyers who adopt the Mediterranean Diet may reduce their risk of depression, cognitive decline, and strokes. ${ }^{768}$

\section{Whole Food Plant-Based Diet}

T. Colin Campbell argues that the best way to eat for optimal health is to consume a variety of plant-based foods (vegetables, fruits, raw nuts and seeds, beans and legumes, and whole grains) in as natural a

\footnotetext{
762 Andreeva \& Kesse-Guyot, supra note 12, at 23-24.

763 Bonaccio, de Gaetano \& Iacoviello, supra note 748, at 40; Lopresti, supra note 317, at $96-97$.

764 Andreeva \& Kesse-Guyot, supra note 12, at 24.

765 Id.

766 Id. at 20.

767 See Bonaccio, de Gaetano \& Iacoviello, supra note 748, at 40.

768 See Andreeva \& Kesse-Guyot, supra note 12, at 24.
} 
condition as possible. ${ }^{769}$ In addition, he recommends avoiding animal products, heavily processed foods, oil, salt, and sugar. ${ }^{770}$ The China Study resulted in two powerful findings: people who consumed the most animal-based food experienced the most chronic disease, and people who consumed the most plant-based food avoided chronic disease and were the healthiest. ${ }^{771}$ The lawyer who chooses to consume a diet rich in whole foods will lower the risk of cognitive decline and the lawyer who eats a higher percentage of processed foods increases risk of cognitive deficits. ${ }^{772}$

Campbell uses three sources of evidence to support his claim that the Whole Food Plant-Based diet is optimal: observational research results, biomimicry, and evolutionary biology. ${ }^{773}$ In observational research, scientists examine the diet and disease characteristics of a population to look for associations between variables. ${ }^{774}$ The China Study revealed that the higher the consumption of animal products by a large ecosystem of people living in rural China, the greater the occurrence of cancer, heart disease, and stroke. ${ }^{775}$ Biomimicry looks to animal diets and demonstrates that chimps, gorillas, hippopotamus, and elephants develop strong and healthy muscle and bone systems eating plant-based diets. ${ }^{776}$ Evolutionary biology compares the body characteristics of herbivores and carnivores and suggests that humans share nearly all the characteristics of herbivores, and few with carnivores. $^{777}$

Campbell concluded that there are multiple benefits to the consumption of plant-based foods and numerous health risks associated with eating animal-based foods. ${ }^{778} \mathrm{He}$ lists a number of world-class athletes that have improved their performance on a plant-based diet. ${ }^{779}$ A number of athletes have chosen a vegan diet to enhance their strength

\footnotetext{
769 THE CHINA STUDY, supra note 9 , at 7.

$770 \mathrm{Id}$. at 7, 24.

771 See THE CHINA STUDY, supra note 9, at 7.

772 Best \& Dye, supra note 17, at 6.

773 CAMPBELL, supra note 409, at 79-82.

774 Id. at 79.

775 Id. at $80-81$.

776 Id. at 81.

777 CAMPBELL, supra note 409, at 82. Examples of the systems that are compared in this research include the digestive system, the shape of the jaw and teeth, and the $\mathrm{pH}$ balance of the stomach. $I d$.

778 THE CHINA STUDY, supra note 9, at 21.

779 Id. at 23-24 (noting that Ironman Dave Scott, tennis champion Martina Navratilova, and track greats Carl Lewis and Edwin Moses eat plant-based diets).
} 
and stamina, but also to reduce the suffering of animals. ${ }^{780}$ The Union of Concerned Scientists 2013 report, The \$11 Trillion Reward, found that if Americans consumed just one more serving of either fruits or vegetables per day, over 30,000 lives could be saved. ${ }^{781}$ Rodent studies confirmed the plant-based diet finding when rats fed a low animal protein diet voluntarily spent more time on the exercise wheel and suffered from less fatigue than rats fed a chow loaded with animal protein. ${ }^{782}$ Diseases of the brain can also be reduced or eliminated with the adoption of a largely plant-based diet. ${ }^{783}$ A longitudinal study of 272 Californians showed that those participants who skipped meat (vegans and vegetarians) were one third as likely to develop Alzheimer's disease as the carnivores. ${ }^{784}$

Campbell's research presents a strong argument for lawyers to act immediately to make dietary changes, and nutrition modification will happen only one lawyer at a time. ${ }^{785} \mathrm{He}$ also argues that food policy will change only after a sufficient number of individuals experience the benefits of a Whole Food Plant-Based diet. ${ }^{786}$ Who better to lead a food revolution than healthy lawyers?

\section{Diet Recommendations for the Prevention of Alzheimer's Disease}

The following are a set of dietary guidelines, presented at the 2013 Conference on Nutrition and the Brain, designed to help prevent Alzheimer's disease:

1. Carbohydrates: Replace meat and dairy with vegetables, fruits, legumes (beans, peas, lentils), and whole grains.

2. Fats: Minimize saturated fats found in dairy, meats, and oils (coconut, palm, corn, canola); Minimize Trans fats in snack and

780 The Compassionate Athlete: Athletes Tackle Questions About Plant-Based Eating, VEGAN OUTREACH (Apr. 2016), http://veganoutreach.org/CA.pdf (including athletes from football, hockey, wrestling, skiing, bodybuilding, and UFC).

781 The \$11 Trillion Reward: How Simple Dietary Changes Can Save Lives AND MONeY, AND How We Get THERE, UNiON OF CONCERNED SCIENTISTS 1, 5 (2013), http://www.ucsusa.org/sites/default/files/legacy/assets/documents/food_and_agriculture/11 -trillion-reward.pdf (finding that an additional serving of vegetables or fruits could also save five billion dollars in medical costs).

782 THE CHINA STUDY, supra note 9, at 24.

783 See Best \& Dye, supra note 17, at 3.

784 BARNARD, supra note 218 , at 49.

785 CAMPBELL, supra note 409, at 289.

786 Id. at 289-90. 
fried foods (partially hydrogenated oils); and replace with olive and avocado oils (monounsaturated fatty acids).

3. Supplements: Acquire Vitamin E from foods, rather than supplements (three meals of fish or seafood per week for nonvegetarians); Folic Acid should be acquired either from food or a supplement; Vitamin $B_{12}$ should be consumed from a supplement; and if multiple vitamins are used, choose supplements without iron and copper. DHA and EPA supplementation in animals has increased synaptic membranes and dendritic spines in hippocampal cells of normal animals. ${ }^{787}$ Researchers hypothesize that if this could be replicated in human brains, this treatment might help cognitive decline in patients with neurodegenerative diseases (dementia, Alzheimer's) or brain injuries, including strokes. ${ }^{788}$

4. Aluminum: Minimize exposure by selecting cookware, baking powder, antacids, antiperspirants, frozen pizza cheese, pickle relish, single-serving creamers and salt packets without aluminum present and limiting use of soda cans and foil. ${ }^{789}$

\section{Diet Recommendations for the Prevention or Improvement of Depression}

1. Foods: B Vitamins ( $\mathrm{B}_{6}, \mathrm{~B}_{12}$, and folate), work to remove homocysteine from the blood. ${ }^{790}$ Foods rich in folate include asparagus, broccoli, green leafy vegetables, and spinach. ${ }^{791}$ For foods containing Vitamin $\mathrm{B}_{6}$, eat bananas, beans, green vegetables, nuts, sweet potatoes, and whole grains. ${ }^{792}$ Vitamin $\mathrm{B}_{12}$ can be consumed in fortified breakfast cereals or fortified soy milk. ${ }^{793}$ Fish with the highest Omega-3 are herring, salmon, mackerel, and Bluefin tuna. ${ }^{794}$

2. Supplements: Lawyers suffering from depression, or those wishing to stave off depression, should check with their doctors on adding the supplements that research indicates have an impact

\footnotetext{
787 LEYSE-WALLACE, supra note 25, at 88.

788 Id. at 89.

789 Jager \& Ahmed, supra note 676, at 206-07; BARNARD, supra note 218, at 39-42; LEYSE-WALLACE, supra note 25 , at 87.

790 BARNARD, supra note 218, at 71-73.

791 Id. at 74 .

792 Id.

793 Id. at 75.

${ }^{794}$ LEYSE-WALLACE, supra note 25, at 221-22.
} 
on depression including folic acid, Vitamin $\mathrm{B}_{6}$, Vitamin $\mathrm{B}_{12}$, Vitamin D, Omega-3, and EPA. ${ }^{795}$ Vitamin $\mathrm{B}_{12}$ is one of the rare micronutrients that is best ingested from a supplement, or from fortified breakfast cereals or fortified soy milk. ${ }^{796}$ It is poorly absorbed from animal products and not found in plants. ${ }^{797}$

\section{B. Neuro-Protective Nutrition Practices}

He that takes medicine and neglects diet wastes the skills of a physician.

$$
\text { -Chinese Proverb }{ }^{798}
$$

The lawyer's nutritional practices, the fuel she chooses to consume, can offer protection against cognitive decline. ${ }^{799}$ Dietary choices can impact neurotransmitter and signal transduction pathways, synaptic connections between neurons, membrane fluidity, and neurogenesis. ${ }^{800}$

\section{It's Never Too Late to Start}

The most famous pediatrician, Dr. Benjamin Spock, was very athletic as a young man, winning a gold medal on the Yale rowing crew at the 1924 Olympics. ${ }^{801}$ In his eighties, he experienced numerous health problems: recurrent pneumonia, fluid around his heart and lungs due to exposure to tuberculosis, and chronic neuropathy that made it difficult to walk. ${ }^{802}$ His doctors told him his only recourse was to use a wheel chair, install an elevator in his home, and wait for the end. ${ }^{803}$ Upon getting the quote for the pricey elevator, Dr. Spock decided to try major dietary changes. ${ }^{804} \mathrm{He}$ eliminated meat and cheese, and moved to a diet rich in vegetables and whole grains. ${ }^{805}$ His sleep improved within days, his strength and energy returned within three weeks, and he lost fifty pounds of fluid within six weeks. ${ }^{806} \mathrm{Dr}$. Spock became an

\footnotetext{
795 Id. at 98, 100-02, 107-09, 116, 221.

796 BARNARD, supra note 218, at 75.

${ }^{797}$ Id. at 75-76.

798 BHATIA, supra note 8, at 7.

799 Best \& Dye, supra note 17, at 5; Lephart, supra note 231, at 145.

800 Best \& Dye, supra note 17 , at 5.

801 BARNARD, supra note 218 , at 82.

802 Id. at $82-83$.

$803 \mathrm{Id}$. at 83 .

${ }^{804}$ Id.

805 Id.

806 Id.
} 
advocate of plant-based diets and lived until he was nearly ninety-five years old. ${ }^{807}$

\section{Reasons to Get Started}

Just as Dr. Dean Ornish demonstrated in 1990 that it was possible to reverse heart disease, ${ }^{808}$ it is possible to reverse harm to the lawyer brain. ${ }^{809}$ There are many reasons for a lawyer to start improving her brain power with better nutrition: to optimize her professional capacity, to reduce the environmental damage factory farming causes from increasing greenhouse gases and pesticide use, to remove herself from the American food cycle that consumes more than one million animals per hour, ${ }^{810}$ and to better care for herself and her family and model healthy habits for her children.

\section{Five Simple Ways to Start}

Eat food that you want your brain cells to be built of.

$$
\text { -David Katz, MD }{ }^{811}
$$

1. Partake of breakfast every day to avoid overeating later and to prevent your body from storing more fat, because the duration between meals throws your metabolism into starvation mode. ${ }^{812}$

2. Eat smaller meals and snacks frequently to maintain consistent blood sugar levels. ${ }^{813}$

3. Eat a big salad every day. ${ }^{814}$ Include dark leafy greens because the greatest nutrition value is contained in the darkest greens. ${ }^{815}$ Dress your salad with vinegar and a little olive oil to reduce the rise of blood glucose. ${ }^{816}$ Your olive oil should be cold-pressed extra-virgin, come in a dark bottle, and be consumed within a few months of purchase because light, air, and time reduce the nutrition benefits. ${ }^{817}$ Add an avocado to your salad to help your




body absorb more of the antioxidants in the other salad ingredients. ${ }^{818}$

4. Drink coffee, tea, and water. ${ }^{819}$ Coffee is comparable to fruit as a source of polyphenol antioxidants. ${ }^{820}$ Tea contains antioxidant polyphenols called catechins. ${ }^{821}$ The half-life of caffeine is about six hours. Thus, your coffee or tea from " 8 a.m. is half gone by 2 p.m., and three-quarters gone by 8 p.m." 822

5. Snack on about a $1 / 4$ cup of a variety of nuts because they contain a variety of antioxidants. ${ }^{823}$ Use nuts and seeds as an ingredient, sprinkling them on salad or yogurt, or adding them to sauces or smoothies. ${ }^{824}$

\section{Eating Tips: Carbs}

Eat as if your brain depends on it.

$$
\text { -Travis Stork, } \mathrm{MD}^{825}
$$

- Choose healthy carbs to limit their power to stimulate the addict brain. 826

- Slash sugar consumption to reduce cravings; improve immune function; lower risk of weight gain, heart disease, cancer, diabetes, extra wrinkles, learning and memory problems, and irreparable glycation. ${ }^{827}$ Use stevia to sweeten. ${ }^{828}$ Reduce consumption of wheat products. ${ }^{829}$

- Consume a pound of produce a day, the more colorful the better including "all the colors of the brainbow," ${ }^{830}$ to ingest powerful antioxidants, vitamins, minerals, and fiber. ${ }^{831}$ If veggies such as

\footnotetext{
818 Id. at 33.

819 BHATIA, supra note 8, at 37-38, 53-54; ELLIE WHITNEY \& SHARON RADY ROLFES, UNDERSTANDING NUTRITION 376 (14th ed. 2015); SMITH \& COLLENE, supra note 5, at 39.

820 BHATIA, supra note 8 , at 38 .

821 Id. at 53.

822 BARNARD, supra note 218, at 125.

823 Id. at 45.

824 See BARNARD, supra note 218, at 70, 163.

825 BHATIA, supra note 8, at 281.

826 Id. at 298.

827 Id. at 68-69, 245, 295, 321; KORN, supra note 312, at 10; Francis \& Stevenson, supra note 255 , at 112; DAVIS, supra note 286, at 133-34.

828 BHATIA, supra note 8, at 318.

829 DAVIS, supra note 286, at 35, 139.

830 KORN, supra note 312 , at 14; FUHRMAN, supra note 485, at 117-18.

831 BHATIA, supra note 8, at 67, 273.
} 
broccoli, brussels sprouts, or spinach are too bitter to be appetizing, spritz them with lemon juice or apple cider vinegar to mellow and sweeten the taste. ${ }^{832}$

- Opt for organic produce to avoid pesticides and limit risk for obesity, diabetes, depression, stroke, and Parkinson's disease. ${ }^{833}$ Refer to the Environmental Working Group's Dirty Dozen and Clean Fifteen lists. ${ }^{834}$

- Plan on getting vitamins and nutrients primarily from whole foods. ${ }^{835}$ The supplements doctors most commonly take themselves and also recommend to patients are: Vitamin D; Vitamin $\mathrm{B}_{12}$; fish oil or fish and flax oil combined or EPA/DHA (for Omega-3 fatty acids); and probiotics. ${ }^{836}$

- Snack on the ABCs: apples, bananas, and carrots, for increased fiber with low calorie counts. ${ }^{837}$

- Experiment with gluten-free (gluten is the protein in wheat and barley) for one month to see if you improve digestive issues, joint pain, skin rashes, brain fogginess, and/or blue moods. ${ }^{838}$

\section{Eating Tips: Protein}

- Increase quality protein as you reduce sugar. ${ }^{839}$

- Reduce meat and increase fish intake to improve your Omega6/Omega-3 balance. ${ }^{840}$

- If you eat meat, adopt a healthy portion limit — the size of your fist. $^{841}$

- Increase plant protein: soy Beans, quinoa, millet, beans and rice, and vegetables and nuts. ${ }^{842}$

832 BARNARD, supra note 218, at 159.

833 BHATIA, supra note 8, at 253, 325; Farooqui \& Farooqui, supra note 272, at 17.

834 EWG's 2016 Shopper's Guide to Pesticides in Produce, ENVTL. WORKING GRP., http://www.ewg.org/foodnews/?gclid=Cj0KEQjwuLKtBRDPicmJyvu_qZMBEiQAzlGN5 g_4OMbyf_qvesPMIHMXZq3iMCCIDyD8R6EgF162-_UaAqXc8P8HAQ (last visited Mar. 28, 2017).

835 BHATIA, supra note 8 , at 281, BARNARD, supra note 218, at 68-70, 73-76.

836 BHATIA, supra note 8, at 202-03; BARNARD, supra note 218, at 75 .

837 BHATIA, supra note 8 , at 291, 319. Bananas also contain blood pressure-lowering potassium. Id.

838 Id. at 204-05, 208, 227, 245.

839 KORN, supra note 312, at 10.

840 BHATIA, supra note 8 , at 67-68.

841 Id. at 136.

842 KORN, supra note 312 , at 9. 
- Eliminate meat one or two days a week in favor of vegetarian meals. $^{843}$

- Choose organic eggs and organic and/or wild meats to limit exposure to additives, preservatives, hormones, and pesticides. ${ }^{844}$

\section{Eating Tips: Fats}

- Embrace healthy fats to make your brain more efficient and aid nutrient absorption from other foods. ${ }^{845}$

- Increase Omega-3 fats to improve brain and cardiovascular health. ${ }^{846}$

- Pair carbs with healthy fats to slow glucose conversion and feel satiated. $^{847}$

- Eliminate, or significantly minimize, unhealthy oils (corn, safflower, soybean, sunflower) to improve your Omega6/Omega-3 balance. ${ }^{848}$

- Snack on nuts or dark chocolate to maintain stable blood sugar levels and keep your metabolism revved up with a steady intake of good nutrients to digest. ${ }^{849}$

\section{Eating Tips: Vitamins and Minerals}

- Obtain vitamins and minerals from whole foods because of their antioxidants and fiber: fruits, vegetables, whole grains, and legumes. ${ }^{850}$

- Check with your doctor about including supplements in your diet and ask about: Vitamin D and Vitamin $\mathrm{B}_{12}$; for Omega-3 and EPA/DHA, flax oil, fish oil, or flax/fish oil combined; and probiotics. ${ }^{851}$

\section{Eating Tips: Habits}

- Integrate good habits first, then work on eliminating bad habits. ${ }^{852}$

\footnotetext{
843 SMITH \& COLLENE, supra note 5, at 39.

844 KORN, supra note 312, at 14.

845 BHATIA, supra note 8 , at 63.

846 BARNARD, supra note 218, at 59; SMITH \& COLLENE, supra note 5, at 164.

847 BHATIA, supra note 8, at 62-63, 142.

848 BARNARD, supra note 218, at 161.

849 BHATIA, supra note 8, at 205, 209, 219, 223, 277.

850 Id. at 281; BARNARD, supra note 218 , at 68-70, 73-76.

851 BHATIA, supra note 8, at 202-03; BARNARD, supra note 218 , at 75.

852 KORN, supra note 312 , at 14-15.
} 
- Thwart emotional eating by: distinguishing between head hunger and real hunger, managing stress, and eating mindfully to limit stress hormone-related excess fat storage and to gain more nutritional value from your food. ${ }^{853}$

- Eat when relaxed to empower the parasympathetic rest-and-digest system and avoid digestion problems. ${ }^{854}$

- Shop at the outsides of the grocery store to limit the incentive salience of highly processed and sweet-laden food, usually shelved in the center aisles. ${ }^{855}$

- Embrace the ritual of preparing fresh food daily. Choose guiltypleasure television or pod-casts to entertain you during food preparation. ${ }^{856}$

- Keep your kitchen neat because a cluttered and chaotic kitchen causes people to eat more calories and select less healthy foods. ${ }^{857}$

- Consider using a subscription food service to help you prepare fresh food at home. Blue Apron ${ }^{858}$ provides meal plans for meat eaters and vegetarians and Purple Carrot ${ }^{859}$ supplies vegan meal kits.

- To establish good habits, keep a log of food consumed and daily activities. $^{860}$

Love food that loves you back.

-David Katz, MD 861

\section{Foods with Superpowers}

Although there is no legal definition of superfood, foods high in phytochemicals are often described as superfoods. ${ }^{862}$ Variety is an

853 BHATIA, supra note 8, at 69-70, 156-57.

854 See KORN, supra note 312, at 13-14.

855 Grocery Store Secret: Shop the Perimeter, MAYO ClinIC (Aug. 6, 2014), http://www.mayoclinic.org/healthy-lifestyle/nutrition-and-healthy-eating/in-depth/health -tip/art-20048842.

856 KORN, supra note 312, at 24-25.

857 LenNy R. VARTANian, Kristin Kernan \& Brian Wansink, Clutter, ChaOs, AND OVERCONSUMPTION: THE ROLE OF MiND-SET IN STRESSFUl AND CHAOTIC FOOD ENVIRONMENTS, CORNELL UNIVERSITY FOOD \& BRAND LAB 9-10 (2016).

858 BLUE APRON, https://www.blueapron.com/ (last visited Mar. 28, 2017).

859 THE PURPLE CARROT, https://thepurplecarrot.com/ (last visited Mar. 28, 2017).

860 Food and Physical Activity Trackers, AM. DiABETES Assoc. (May 15, 2015), http://www.diabetes.org/food-and-fitness/weight-loss/getting-started/food-and-physical -activity.html.

861 BHATIA, supra note 8, at 277.

862 See SMITH \& COLLENE, supra note 5, at 13. 
important component of maintaining good physical and mental health, so lawyers should strive to incorporate as many of the foods with superpowers as possible. ${ }^{863}$ The following chart includes food that are rich in phytochemicals, polyphenols, Omega-3 fatty acids, healthy proteins, prebiotics, and probiotics. ${ }^{864}$

Table 3. Nutrient-rich Foods

\begin{tabular}{|c|c|c|c|}
\hline \multicolumn{4}{|c|}{ Fruits and Vegetables } \\
\hline & Key Nutrients & Protects Against & Brain Benefits \\
\hline Apples & $\begin{array}{l}\text { Antioxidants, } \\
\text { Soluble Fiber }\end{array}$ & $\begin{array}{l}\text { Heart Disease, } \\
\text { High Cholesterol, } \\
\text { Obesity, and } \\
\text { Stroke }\end{array}$ & Antioxidants \\
\hline Apricots & $\begin{array}{l}\text { Phytochemicals, } \\
\text { Polyphenols }\end{array}$ & Oxidative stress & $\begin{array}{l}\text { Likely } \\
\text { antioxidants }\end{array}$ \\
\hline Asparagus & $\begin{array}{l}\text { Folate, Glutathione, } \\
\text { Inulin, and Saponins }\end{array}$ & $\begin{array}{l}\text { Cancer, Obesity, } \\
\text { Digestive Upset } \\
\text { and Bloating }\end{array}$ & $\begin{array}{l}\text { Prebiotic } \\
\text { Folate works to } \\
\text { reduce } \\
\text { homocysteine in } \\
\text { blood, which } \\
\text { increases MCI } \\
\text { and } \\
\text { Alzheimer's } \\
\text { risk }\end{array}$ \\
\hline Beets & $\begin{array}{l}\text { Phytochemicals, } \\
\text { Polyphenols }\end{array}$ & Oxidative stress & $\begin{array}{l}\text { Likely } \\
\text { antioxidants }\end{array}$ \\
\hline Berries & $\begin{array}{l}\text { Anthocyanins, } \\
\text { Antioxidants, Fiber, } \\
\text { and Vitamin C, } \\
\text { Phytochemicals }\end{array}$ & $\begin{array}{l}\text { Cancer, Diabetes, } \\
\text { Heart Disease, } \\
\text { Memory Loss, } \\
\text { and Obesity }\end{array}$ & $\begin{array}{l}\text { Delay age- } \\
\text { related } \\
\text { cognitive } \\
\text { decline } \\
\end{array}$ \\
\hline Blueberries & $\begin{array}{l}\text { Phytochemicals, } \\
\text { Polyphenols }\end{array}$ & Oxidative stress & $\begin{array}{l}\text { Likely } \\
\text { antioxidants }\end{array}$ \\
\hline Broccoli & $\begin{array}{l}\text { Fiber, Folate, } \\
\text { Sulforaphane, and } \\
\text { Vitamin C, } \\
\text { Polyphenols }\end{array}$ & $\begin{array}{l}\text { Cancer and Heart } \\
\text { Disease }\end{array}$ & $\begin{array}{l}\text { Folate works to } \\
\text { reduce } \\
\text { homocysteine in } \\
\text { blood, which } \\
\text { increases MCI } \\
\text { and } \\
\text { Alzheimer's } \\
\text { risk }\end{array}$ \\
\hline
\end{tabular}

863 See id. at 38-39.

864 BARNARD, supra note 218, at 69-76; BHATIA, supra note 8, at 29-56, 299; DRUMMOND \& BREFERE, supra note 437, at 222-23; KORN, supra note 312, at 9; SMITH \& COLLENE, supra note 5, at 14, 38-39; WILLIAMS, supra note 415 , at 58. 


\begin{tabular}{|c|c|c|c|}
\hline \multicolumn{4}{|c|}{ Fruits and Vegetables } \\
\hline & Key Nutrients & Protects Against & Brain Benefits \\
\hline $\begin{array}{l}\text { Brussels } \\
\text { Sprouts }\end{array}$ & $\begin{array}{l}\text { Phytochemicals, } \\
\text { Polyphenols }\end{array}$ & Oxidative stress & $\begin{array}{l}\text { Likely } \\
\text { antioxidants }\end{array}$ \\
\hline Cabbage & $\begin{array}{l}\text { Phytochemicals, } \\
\text { Polyphenols }\end{array}$ & Oxidative stress & $\begin{array}{l}\text { Likely } \\
\text { antioxidants }\end{array}$ \\
\hline Cauliflower & $\begin{array}{l}\text { Phytochemicals, } \\
\text { Polyphenols }\end{array}$ & Oxidative stress & $\begin{array}{l}\text { Likely } \\
\text { antioxidants }\end{array}$ \\
\hline Carrots & $\begin{array}{l}\text { Phytochemicals, } \\
\text { Polyphenols }\end{array}$ & Oxidative stress & $\begin{array}{l}\text { Likely } \\
\text { antioxidants }\end{array}$ \\
\hline Cherries & $\begin{array}{l}\text { Phytochemicals, } \\
\text { Polyphenols }\end{array}$ & Oxidative stress & $\begin{array}{l}\text { Likely } \\
\text { antioxidants }\end{array}$ \\
\hline Citrus Fruits & $\begin{array}{l}\text { Vitamin C, } \\
\text { Polyphenols }\end{array}$ & Oxidative stress & Antioxidant $^{865}$ \\
\hline Cranberries & Phytochemicals & Oxidative stress & $\begin{array}{l}\text { Likely } \\
\text { antioxidants }\end{array}$ \\
\hline $\begin{array}{l}\text { Dark Leafy } \\
\text { Greens (Kale, } \\
\text { Spinach, } \\
\text { Romaine } \\
\text { Lettuce) }\end{array}$ & $\begin{array}{l}\text { Calcium, } \\
\text { Carotenoids, Fiber, } \\
\text { Folate, Iron, } \\
\text { Vitamins C, E, and } \\
\text { K }\end{array}$ & $\begin{array}{l}\text { Cancer, Diabetes, } \\
\text { Macular } \\
\text { Degeneration, } \\
\text { and Obesity }\end{array}$ & $\begin{array}{l}\text { Folate works to } \\
\text { reduce } \\
\text { homocysteine in } \\
\text { blood, which } \\
\text { increases MCI } \\
\text { and } \\
\text { Alzheimer's } \\
\text { risk }^{866}\end{array}$ \\
\hline Eggplant & $\begin{array}{l}\text { Phytochemicals, } \\
\text { Polyphenols }\end{array}$ & Oxidative stress & $\begin{array}{l}\text { Likely } \\
\text { antioxidants }\end{array}$ \\
\hline Garlic & $\begin{array}{l}\text { Phytochemicals, } \\
\text { Polyphenols }\end{array}$ & Oxidative stress & $\begin{array}{l}\text { Likely } \\
\text { antioxidants }\end{array}$ \\
\hline Grapes & $\begin{array}{l}\text { Phytochemicals, } \\
\text { Polyphenols ls }\end{array}$ & Oxidative stress & $\begin{array}{l}\text { Likely } \\
\text { antioxidants }\end{array}$ \\
\hline Green Peas & $\begin{array}{l}\text { Phytochemicals, } \\
\text { Polyphenols }\end{array}$ & Oxidative stress & $\begin{array}{l}\text { Likely } \\
\text { antioxidants }\end{array}$ \\
\hline Green Tea & $\begin{array}{l}\text { Phytochemicals, } \\
\text { Polyphenols }\end{array}$ & Oxidative stress & $\begin{array}{l}\text { Likely } \\
\text { antioxidants }\end{array}$ \\
\hline $\begin{array}{l}\text { Honeydew } \\
\text { Melon }\end{array}$ & $\begin{array}{l}\text { Phytochemicals, } \\
\text { Polyphenols }\end{array}$ & Oxidative stress & $\begin{array}{l}\text { Likely } \\
\text { antioxidants }\end{array}$ \\
\hline Hot Peppers & $\begin{array}{l}\text { Phytochemicals, } \\
\text { Polyphenols }\end{array}$ & Oxidative stress & $\begin{array}{l}\text { Likely } \\
\text { antioxidants }\end{array}$ \\
\hline Kale & $\begin{array}{l}\text { Phytochemicals, } \\
\text { Polyphenols }\end{array}$ & Oxidative stress & $\begin{array}{l}\text { Likely } \\
\text { antioxidants }\end{array}$ \\
\hline
\end{tabular}

865 WILLIAMS, supra note 415 , at 58 .

866 Id. 


\begin{tabular}{|c|c|c|c|}
\hline \multicolumn{4}{|c|}{ Fruits and Vegetables } \\
\hline & Key Nutrients & Protects Against & Brain Benefits \\
\hline Mangoes & $\begin{array}{l}\text { Carotenoids, Fiber, } \\
\text { Vitamin C, and } \\
\text { Vitamin E }\end{array}$ & $\begin{array}{l}\text { Diabetes, } \\
\text { Digestive } \\
\text { Problems, Heart } \\
\text { Disease, and } \\
\text { Obesity }\end{array}$ & $\begin{array}{l}\text { Likely } \\
\text { antioxidants }\end{array}$ \\
\hline Nectarines & $\begin{array}{l}\text { Phytochemicals, } \\
\text { Polyphenols }\end{array}$ & Oxidative stress & $\begin{array}{l}\text { Likely } \\
\text { antioxidants }\end{array}$ \\
\hline Onions & $\begin{array}{l}\text { Phytochemicals, } \\
\text { Polyphenols }\end{array}$ & Oxidative stress & $\begin{array}{l}\text { Likely } \\
\text { antioxidants }\end{array}$ \\
\hline Papaya & $\begin{array}{l}\text { Phytochemicals, } \\
\text { Polyphenols }\end{array}$ & Oxidative stress & $\begin{array}{l}\text { Likely } \\
\text { antioxidants }\end{array}$ \\
\hline Peaches & $\begin{array}{l}\text { Phytochemicals, } \\
\text { Polyphenols }\end{array}$ & Oxidative stress & $\begin{array}{l}\text { Likely } \\
\text { antioxidants }\end{array}$ \\
\hline Peanuts & $\begin{array}{l}\text { Phytochemicals, } \\
\text { Polyphenols }\end{array}$ & Oxidative stress & $\begin{array}{l}\text { Likely } \\
\text { antioxidants }\end{array}$ \\
\hline Pears & $\begin{array}{l}\text { Phytochemicals, } \\
\text { Polyphenols }\end{array}$ & Oxidative stress & $\begin{array}{l}\text { Likely } \\
\text { antioxidants }\end{array}$ \\
\hline $\begin{array}{l}\text { Peppers } \\
\text { Yellow }\end{array}$ & $\begin{array}{l}\text { Phytochemicals, } \\
\text { Polyphenols }\end{array}$ & Oxidative stress & $\begin{array}{l}\text { Likely } \\
\text { antioxidants }\end{array}$ \\
\hline Pineapple & $\begin{array}{l}\text { Phytochemicals, } \\
\text { Polyphenols }\end{array}$ & Oxidative stress & $\begin{array}{l}\text { Likely } \\
\text { antioxidants }\end{array}$ \\
\hline Plums & $\begin{array}{l}\text { Phytochemicals, } \\
\text { Polyphenols }\end{array}$ & Oxidative stress & $\begin{array}{l}\text { Likely } \\
\text { antioxidants }\end{array}$ \\
\hline Prunes & $\begin{array}{l}\text { Phytochemicals, } \\
\text { Polyphenols }\end{array}$ & Oxidative stress & $\begin{array}{l}\text { Likely } \\
\text { antioxidants }\end{array}$ \\
\hline Raisins & $\begin{array}{l}\text { Phytochemicals, } \\
\text { Polyphenols }\end{array}$ & Oxidative stress & $\begin{array}{l}\text { Likely } \\
\text { antioxidants }\end{array}$ \\
\hline Red Cabbage & $\begin{array}{l}\text { Phytochemicals, } \\
\text { Polyphenols }\end{array}$ & Oxidative stress & $\begin{array}{l}\text { Likely } \\
\text { antioxidants }\end{array}$ \\
\hline $\begin{array}{l}\text { Soy Beans and } \\
\text { Soy Milk }\end{array}$ & $\begin{array}{l}\text { Phytochemicals, } \\
\text { Polyphenols }\end{array}$ & Oxidative stress & $\begin{array}{l}\text { Likely } \\
\text { antioxidants }\end{array}$ \\
\hline Strawberries & Vitamin C & Oxidative stress & Antioxidant $^{867}$ \\
\hline Sweet Potatoes & $\begin{array}{l}\text { Phytochemicals, } \\
\text { Polyphenols }\end{array}$ & Oxidative stress & $\begin{array}{l}\text { Likely } \\
\text { antioxidants }\end{array}$ \\
\hline Tomatoes & $\begin{array}{l}\text { Phytochemicals, } \\
\text { Polyphenols }\end{array}$ & Oxidative stress & $\begin{array}{l}\text { Likely } \\
\text { antioxidants }\end{array}$ \\
\hline Whole Grains & $\begin{array}{l}\text { Vitamin E, } \\
\text { Polyphenols }\end{array}$ & Oxidative stress & $\begin{array}{l}\text { Likely } \\
\text { antioxidants }\end{array}$ \\
\hline
\end{tabular}




\begin{tabular}{|c|c|c|c|}
\hline \multicolumn{4}{|l|}{ Protein } \\
\hline & Key Nutrients & Protects Against & Brain Benefits \\
\hline $\begin{array}{l}\text { Beans } \\
\text { and } \\
\text { Legumes }^{868}\end{array}$ & $\begin{array}{l}\text { Antioxidants, } \\
\text { Folate, Potassium, } \\
\text { Protein, Soluble } \\
\text { Fiber, } \\
\text { Phytochemicals }\end{array}$ & $\begin{array}{l}\text { Diabetes, Heart } \\
\text { Disease, and } \\
\text { Obesity }\end{array}$ & $\begin{array}{l}\text { Vitamin } B_{6} \\
\text { works to reduce } \\
\text { homocysteine in } \\
\text { blood, which } \\
\text { increases MCI } \\
\text { and } \\
\text { Alzheimer's } \\
\text { risk }\end{array}$ \\
\hline Buckwheat $^{869}$ & Flavonoids & $\begin{array}{l}\text { High Blood } \\
\text { Pressure and } \\
\text { Cholesterol, } \\
\text { Diabetes }\end{array}$ & \\
\hline Eggs & $\begin{array}{l}\text { Antioxidants, } \\
\text { Choline, Omega-3 } \\
\text { Fatty Acids, and } \\
\text { Protein }\end{array}$ & $\begin{array}{l}\text { Cancer, Macular } \\
\text { Degeneration, } \\
\text { and Obesity }\end{array}$ & $\begin{array}{l}\text { Protein } \\
\text { becomes } \\
\text { dopamine, } \\
\text { norepinephrine, } \\
\text { and epinephrine } \\
\text { increasing } \\
\text { alertness, } \\
\text { energy, and } \\
\text { mood }\end{array}$ \\
\hline $\begin{array}{l}\text { Nuts, Nut } \\
\text { Butters, and } \\
\text { Seeds } \\
\text { (Chia \& Hemp }_{\text {Seeds) }}^{870}\end{array}$ & $\begin{array}{l}\text { Calcium, Healthy } \\
\text { Fats, Magnesium, } \\
\text { Protein, and Vitamin } \\
\text { E }\end{array}$ & $\begin{array}{l}\text { Alzheimer's } \\
\text { Disease, Heart } \\
\text { Disease, and } \\
\text { Obesity }\end{array}$ & $\begin{array}{l}\text { Vitamin E and } \\
\text { Omega-3 fatty } \\
\text { acids protect } \\
\text { against brain } \\
\text { shrinkage and } \\
\text { cognitive } \\
\text { decline. } \\
\text { Vitamin E } \\
\text { neutralizes free } \\
\text { radicals and } \\
\text { reduces risk of } \\
\text { Alzheimer's } \\
\text { disease } \\
\end{array}$ \\
\hline Oats & $\begin{array}{l}\text { Folate, Protein, and } \\
\text { Soluble Fiber }\end{array}$ & $\begin{array}{l}\text { Diabetes, Heart } \\
\text { Disease, and } \\
\text { Obesity }\end{array}$ & \\
\hline
\end{tabular}

868 SMITH \& COLLENE, supra note 5, at 209.

869 BHATIA, supra note 8, at 299 (“'Buckwheat (kasha) isn't a grain, but a fruit seed that is related to rhubarb and sorrel . . . higher in protein than brown rice,"” and it can be substituted for brown rice and the flour can be used in baking).

870 The Doctors, 3 Super-Seeds Everyone Should Be Eating, THE HuFFINGTON Post ENTERTAINMENT (July 23, 2015), http://www.huffingtonpost.com/entry/seeds-to-boost -health_55b088d3e4b0a9b94853b5ff; SMITH \& COLLENE, supra note 5, at 168. 


\begin{tabular}{|c|c|c|c|}
\hline \multicolumn{4}{|l|}{ Protein } \\
\hline & Key Nutrients & Protects Against & Brain Benefits \\
\hline Quinoa & $\begin{array}{l}\text { Antioxidants, Fiber, } \\
\text { Folate, Iron, } \\
\text { Magnesium, } \\
\text { Phosphorus, and } \\
\text { Protein }\end{array}$ & $\begin{array}{l}\text { Cancer, Diabetes, } \\
\text { Heart Disease, } \\
\text { and Obesity }\end{array}$ & \\
\hline Salmon (wild) & $\begin{array}{l}\text { Omega-3 Fatty } \\
\text { Acids, Protein, } \\
\text { Selenium, Vitamin } \\
\text { B12, and Vitamin D }\end{array}$ & $\begin{array}{l}\text { Arthritis, Breast } \\
\text { Cancer, } \\
\text { Depression, } \\
\text { Heart Disease, } \\
\text { Infertility, } \\
\text { Macular } \\
\text { Degeneration, } \\
\text { Memory Loss, } \\
\text { and Skin Cancer }\end{array}$ & $\begin{array}{l}\text { Omega-3s are } \\
\text { the primary } \\
\text { brain fat and } \\
\text { they keep cell } \\
\text { membranes } \\
\text { flexible to } \\
\text { enhance } \\
\text { transmitter } \\
\text { migration }\end{array}$ \\
\hline \multicolumn{4}{|l|}{ Fats } \\
\hline & Key Nutrients & Protects Against & Brain Benefits \\
\hline Avocados & $\begin{array}{l}\text { Beta-Carotene, } \\
\text { Fiber, Folate, Lutein, } \\
\text { Monounsaturated } \\
\text { Fat, Phytosterols, } \\
\text { Potassium, and } \\
\text { Zeaxanthin } \\
\end{array}$ & $\begin{array}{l}\text { Cancer, Diabetes, } \\
\text { Heart Disease, } \\
\text { Macular } \\
\text { Degeneration, } \\
\text { and Obesity }\end{array}$ & $\begin{array}{l}\text { Minimize age- } \\
\text { related memory } \\
\text { decline }\end{array}$ \\
\hline $\begin{array}{l}\text { Fatty Fish } \\
\text { Salmon, Tuna } \\
\text { \& Halibut }^{871}\end{array}$ & Omega-3 fatty acids & $\begin{array}{l}\text { Inflammation } \\
\text { Aids immune and } \\
\text { cardiovascular } \\
\text { systems. } \\
\text { Decreases blood } \\
\text { clotting \& } \\
\text { triglycerides }\end{array}$ & $\begin{array}{l}\text { Part of brain } \\
\text { structure, aids } \\
\text { concentration } \\
\text { and vision, and } \\
\text { decreases } \\
\text { inflammation. }\end{array}$ \\
\hline $\begin{array}{l}\text { Nuts, Nut } \\
\text { Butters, and } \\
\text { Seeds } \\
\text { (Chia \& Hemp }_{\text {Seeds) }}^{872}\end{array}$ & $\begin{array}{l}\text { Calcium, Healthy } \\
\text { Fats, Magnesium, } \\
\text { Protein, Vitamin E, } \\
\text { Antioxidants, Fiber }\end{array}$ & $\begin{array}{l}\text { Alzheimer's } \\
\text { Disease, Heart } \\
\text { Disease, and } \\
\text { Obesity }\end{array}$ & $\begin{array}{l}\text { Vitamin E and } \\
\text { Omega-3 fatty } \\
\text { acids protect } \\
\text { against brain } \\
\text { shrinkage and } \\
\text { cognitive } \\
\text { decline. Vitamin } \\
\text { E neutralizes } \\
\text { free radicals and } \\
\text { reduces risk of } \\
\text { Alzheimer's } \\
\text { disease }\end{array}$ \\
\hline
\end{tabular}

871 SMITH \& COLLENE, supra note 5, at 163-164, 173 Other fatty fish that are rich in Omega-3 include: anchovies, striped bass, catfish, herring, mackerel, sardines, and trout. Id. 872 The Doctors, supra note 870; SMITH \& COLLENE, supra note 5, at 168. 


\begin{tabular}{|c|c|c|c|}
\hline \multicolumn{4}{|l|}{ Protein } \\
\hline & Key Nutrients & Protects Against & Brain Benefits \\
\hline $\begin{array}{l}\text { Nuts/Seeds: } \\
\text { Walnuts, Chia } \\
\text { \& Flax } \\
\text { Seeds }\end{array}$ & $\begin{array}{l}\text { Omega-3 fatty acids, } \\
\text { Antioxidants, Fiber }\end{array}$ & $\begin{array}{l}\text { Inflammation } \\
\text { Aids immune and } \\
\text { cardiovascular } \\
\text { systems. } \\
\text { Decreases blood } \\
\text { clotting \& } \\
\text { triglycerides }\end{array}$ & $\begin{array}{l}\text { Part of brain } \\
\text { structure, aids } \\
\text { concentration } \\
\text { and vision, and } \\
\text { decreases } \\
\text { inflammation }\end{array}$ \\
\hline Olive Oil & $\begin{array}{l}\text { Antioxidants, } \\
\text { Monounsaturated } \\
\text { Fat, and Vitamin K }\end{array}$ & $\begin{array}{l}\text { Bone Loss, } \\
\text { Cancer, Heart } \\
\text { Disease, Obesity, } \\
\text { and Stroke }\end{array}$ & \\
\hline $\begin{array}{l}\text { Oils: Canola \& } \\
\text { Soybean }^{874}\end{array}$ & Omega-3 fatty acids & $\begin{array}{l}\text { Inflammation } \\
\text { Aids immune and } \\
\text { cardiovascular } \\
\text { systems. } \\
\text { Decreases blood } \\
\text { clotting \& } \\
\text { triglycerides }\end{array}$ & $\begin{array}{l}\text { Part of brain } \\
\text { structure, aids } \\
\text { concentration } \\
\text { and vision, and } \\
\text { decreases } \\
\text { inflammation }\end{array}$ \\
\hline \multicolumn{4}{|c|}{ Phytochemicals and Antioxidants } \\
\hline & Key Nutrients & Protects Against & Brain Benefits \\
\hline Coffee $^{875}$ & $\begin{array}{l}\text { Boron, Caffeine, } \\
\text { Chromium, and } \\
\text { Polyphenols }\end{array}$ & $\begin{array}{l}\text { Cancer, Diabetes, } \\
\text { Parkinson's } \\
\text { Disease, and } \\
\text { Stroke }\end{array}$ & $\begin{array}{l}\text { Cuts risk of } \\
\text { Alzheimer's } \\
\text { disease. } \\
\text { Antioxidants }\end{array}$ \\
\hline $\begin{array}{l}\text { Dark } \\
\text { Chocolate }^{876}\end{array}$ & Flavonoids & $\begin{array}{l}\text { Depression, } \\
\text { Diabetes, Heart } \\
\text { Disease, and } \\
\text { Obesity. } \\
\text { Decreases } \\
\text { inflammation }\end{array}$ & $\begin{array}{l}\text { Likely } \\
\text { antioxidants }\end{array}$ \\
\hline Tea & $\begin{array}{l}\text { Caffeine and } \\
\text { Catechins }\end{array}$ & $\begin{array}{l}\text { Arthritis, Bone } \\
\text { Loss, Cancer, } \\
\text { Diabetes, Heart } \\
\text { Disease, Obesity, } \\
\text { Stroke, and Viral } \\
\text { Infections }\end{array}$ & $\begin{array}{l}\text { Likely } \\
\text { antioxidants }\end{array}$ \\
\hline
\end{tabular}

873 SMITH \& COLLENE, supra note 5, at 163-64.

874 Id.

875 BARNARD, supra note 218, at 79.

876 SMITH \& COLLENE, supra note 5, at 193. 


\begin{tabular}{|c|c|c|c|}
\hline \multicolumn{4}{|c|}{ Digestive Health (Second Brain) $^{877}$} \\
\hline & Key Nutrients & Protects Against & Brain Benefits \\
\hline Asparagus & Prebiotic & Harmful bacteria & Prebiotic \\
\hline Bananas & Prebiotic & Harmful bacteria & Prebiotic \\
\hline Bark Flour & Prebiotic & Harmful bacteria & Prebiotic \\
\hline Bran & Prebiotic & Harmful bacteria & Prebiotic \\
\hline Beans & Prebiotic, Fiber & Harmful bacteria & Prebiotic \\
\hline Cactus & Prebiotic & Harmful bacteria & Prebiotic \\
\hline Chia & Prebiotic & Harmful bacteria & Prebiotic \\
\hline Garlic & Prebiotic & Harmful bacteria & Prebiotic \\
\hline Leeks & Prebiotic & Harmful bacteria & Prebiotic \\
\hline Oatmeal & Prebiotic, Fiber & Harmful bacteria & Prebiotic \\
\hline Onion & Prebiotic & Harmful bacteria & Prebiotic \\
\hline Psyllium & Prebiotic & Harmful bacteria & Prebiotic \\
\hline Brewer's Yeast & Probiotic & $\begin{array}{l}\text { Digestive } \\
\text { Problems, Heart } \\
\text { Disease, High } \\
\text { Blood Pressure, } \\
\text { Obesity, and } \\
\text { Osteoporosis }\end{array}$ & Probiotic \\
\hline $\begin{array}{l}\text { Cheese with } \\
\text { live cultures }\end{array}$ & Probiotic & $\begin{array}{l}\text { Digestive } \\
\text { Problems, Heart } \\
\text { Disease, High } \\
\text { Blood Pressure, } \\
\text { Obesity, and } \\
\text { Osteoporosis }\end{array}$ & Probiotic \\
\hline Kefir & Probiotic & $\begin{array}{l}\text { Digestive } \\
\text { Problems, Heart } \\
\text { Disease, High } \\
\text { Blood Pressure, } \\
\text { Obesity, and } \\
\text { Osteoporosis }\end{array}$ & Probiotic \\
\hline Kimchi & Probiotic & $\begin{array}{l}\text { Digestive } \\
\text { Problems, Heart } \\
\text { Disease, High } \\
\text { Blood Pressure, } \\
\text { Obesity, and } \\
\text { Osteoporosis }\end{array}$ & Probiotic \\
\hline
\end{tabular}

877 KORN, supra note 312 , at 5, 50-53. 


\begin{tabular}{|c|c|c|c|}
\hline \multicolumn{4}{|c|}{ Digestive Health (Second Brain) ${ }^{877}$} \\
\hline & Key Nutrients & Protects Against & Brain Benefits \\
\hline Kombucha & Probiotic & $\begin{array}{l}\text { Digestive } \\
\text { Problems, Heart } \\
\text { Disease, High } \\
\text { Blood Pressure, } \\
\text { Obesity, and } \\
\text { Osteoporosis } \\
\end{array}$ & Probiotic \\
\hline Micro-algaes & Probiotic & $\begin{array}{l}\text { Digestive } \\
\text { Problems, Heart } \\
\text { Disease, High } \\
\text { Blood Pressure, } \\
\text { Obesity, and } \\
\text { Osteoporosis }\end{array}$ & Probiotic \\
\hline Miso & Probiotic & $\begin{array}{l}\text { Digestive } \\
\text { Problems, Heart } \\
\text { Disease, High } \\
\text { Blood Pressure, } \\
\text { Obesity, and } \\
\text { Osteoporosis }\end{array}$ & Probiotic \\
\hline Sauerkraut & Probiotic & $\begin{array}{l}\text { Digestive } \\
\text { Problems, Heart } \\
\text { Disease, High } \\
\text { Blood Pressure, } \\
\text { Obesity, and } \\
\text { Osteoporosis }\end{array}$ & Probiotic \\
\hline Yogurt & $\begin{array}{l}\text { Calcium, Potassium, } \\
\text { Probiotics, Protein, } \\
\text { and Vitamin B12 }\end{array}$ & $\begin{array}{l}\text { Digestive } \\
\text { Problems, Heart } \\
\text { Disease, High } \\
\text { Blood Pressure, } \\
\text { Obesity, and } \\
\text { Osteoporosis }\end{array}$ & Probiotic \\
\hline
\end{tabular}

\section{Exercise to Enhance Brain Health}

As a lawyer changes dietary habits, she should also consider adding exercise to her regimen. ${ }^{878}$ Lawyers who exercise can increase dopamine levels, ensuring it becomes part of a regular routine. ${ }^{879}$ In addition to healthy fuel choices, exercise is the other most powerful practice for optimizing brain function. ${ }^{880}$

The lawyer brain requires twenty-five percent of the body's calories, twenty percent of its oxygen, and twenty five percent of its blood flow. ${ }^{881}$ Exercise increases blood flow to the brain, maximizing the

\footnotetext{
878 BARNARD, supra note 218 , at 105 .

879 Id. at 186.

880 RATEY, GO WILD, supra note 71, at 245.

881 AMEN, supra note 18, at 17.
} 
distribution of nutrients and improving the elimination of waste. ${ }^{882}$ Exercise helps keeps the hippocampus healthy by increasing blood flow. ${ }^{883}$

Exercise increases and rebalances dopamine, serotonin, and norepinephrine, improving motivation, reinforcing good habits, enhancing mood, and improving sleep, attention, heartbeat, and blood pressure. ${ }^{884}$ Exercise increases BDNF production, improving neurogenesis and neuroplasticity, and reducing inflammation and oxidative stress. ${ }^{885}$ Along with wise nutrition practices, exercise is the second half of an anti-aging strategy for lawyers designed to prevent disease, protect cognitive function, reduce depression risk, and increase longevity. ${ }^{886}$

\section{CONCLUSION}

A good quality of life for lawyers includes high cognitive function, low levels of depression, strong physical health, and robust social connections. ${ }^{887}$ The lawyer's nutritional practices can offer protection against cognitive decline and disease. ${ }^{88}$ For the lawyer brain, food choices can improve neurotransmitter pathways; synaptic connections between neurons; and neurogenesis. ${ }^{889}$ This Article seeks to increase lawyer NQ and help lawyers and law students develop a food philosophy and anti-aging plan that works to ensure a robust quality of life.

882 MEDINA, supra note 46, at 21-22.

883 CARTER ET AL., The HumAn BRAin, supra note 42, at 65; MedinA, supra note 46, at $21-22$.

884 CARTER ET AL., THE HUMAN BRAIN, supra note 42, at 231; CARTER, MAPPING THE MIND, supra note 18, at 28-29; HORSTMAN, DAY IN THE LIFE, supra note 36, at 8, 34; MEDINA, supra note 46, at 16-17; see RATEY, SPARK, supra note 60, at 36-38; SWEENEY, supra note 44 , at $15,221$.

885 Lopresti, supra note 317, at 99-100.

886 Pandey \& Rizvi, supra note 226, at 126-27.

887 Bonaccio, de Gaetano \& Iacoviello, supra note 748 , at 40.

888 Best \& Dye, supra note 17, at 5; Lephart, supra note 231, at 145.

889 Best \& Dye, supra note 17 , at 5. 
